MARCELO DE CAMARGO FURTADO

\title{
AVALIAÇÃO DAS OPORTUNIDADES DE COMERCIALIZAÇÃO DE NOVAS FONTES DE ENERGIAS RENOVÁVEIS NO BRASIL
}


MARCELO DE CAMARGO FURTADO

\section{AVALIAÇÃO DAS OPORTUNIDADES DE COMERCIALIZAÇÃO DE NOVAS FONTES DE ENERGIAS RENOVÁVEIS NO BRASIL}

Dissertação apresentada à Escola

Politécnica da Universidade de São

Paulo para obtenção do título de Mestre em Engenharia. 
MARCELO DE CAMARGO FURTADO

\title{
AVALIAÇÃO DAS OPORTUNIDADES DE COMERCIALIZAÇÃO DE NOVAS FONTES DE ENERGIAS RENOVÁVEIS NO BRASIL
}

\author{
Dissertação apresentada à Escola \\ Politécnica da Universidade de São \\ Paulo para obtenção do título de \\ Mestre em Engenharia.
}

Área de concentração - Sistemas de Potência

Orientadora: Profa. Dra. Eliane Aparecida Faria Amaral Fadigas 


\section{DEDICATÓRIA}

A todas e todos que ajudam a construir um Brasil sustentável e mais justo. 


\section{AGRADECIMENTOS}

A Thais, Martim e Luiza que dedicaram muito amor, horas da família e contribuíram com forte apoio.

A minha orientadora Profa. Dra. Eliane Aparecida Faria Amaral Fadigas, pela paciência, sugestões e apoio.

Ao Professor Marco Antonio Saidel e Fernando Almeida Prado pelo apoio e contribuição neste trabalho.

Ao amigo e colega Ricardo Baitelo pelas valiosas dicas, sugestões e contribuições para a realização desta dissertação e disponibilidade para revisão e comentários.

Aos amigos e colegas Steve Sawyer, Sven Teske e José Luiz Garcia que da Holanda, Alemanha, e da Espanha contribuíram com sugestões, bibliografia, e dados relevantes.

Aos amigos da EQAO que contribuíram com sua experiência, dados e comprometimento com as energias renováveis.

Ao Prof. Goldemberg pelo estímulo, avaliações objetivas e inspiração.

Aos meus pais que ao longo da minha vida estimularam muito o meu desenvolvimento pessoal e profissional. E em especial ao meu pai que sempre esteve ao meu lado no inicio, no meio e no final da produção desta dissertação.

A todos aqueles que direta ou indiretamente contribuíram para este trabalho pois sem amigos e família a vida é muito sem graça.

A Greenpeace que me inspirou a acreditar que meu trabalho pode contribuir para o desenvolvimento de um mundo melhor, mais justo e mais sustentável. 


\section{RESUMO}

As energias renováveis têm lugar de destaque entre as soluções de combate ao aquecimento global, mas seu potencial ainda é subaproveitado no Brasil. Este trabalho visa apresentar argumentos político-estratégicos, socioambientais e econômico-financeiros necessários para viabilizar o desenvolvimento da comercialização de novas fontes de energias renováveis e, consequentemente, o estabelecimento de um mercado nacional maduro para estas fontes. São apresentadas justificativas socioambientais e técnicas para ampliar a produção de energia elétrica a partir de novas fontes renováveis como eólica, biomassa, solar e pequenas centrais hidroelétricas. Foi abordado o importante papel da política tarifária e o atual modelo do setor elétrico, assim como o forte impacto dos encargos e tributos sobre o preço final da energia e as questões relacionadas à revisão tarifária e seu impacto em áreas rurais e urbanizadas. Foi apresentado um cenário de participação das novas fontes de energias renováveis na matriz elétrica brasileira indicando 0 forte potencial de expansão destas fontes, valorizando a descentralização e diversificação da matriz para promoção da equidade e justiça e desvinculação entre o crescimento econômico e a ampliação da geração de energia. Foram apresentados vários modelos de mercado e concluiu-se que o modelo da competição no varejo é a melhor opção para a viabilização de uma comercializadora de novas fontes de energias renováveis. Foram apresentados estudos de casos em diversos países da Europa, Ásia e Américas e a análise de seus pontos mais interessantes visando contribuir para o desenvolvimento de um marco regulatório específico para fomentar um mercado nacional de energias renováveis. Entre as políticas referidas estão o sistema de cotas; sistema de licitação; subsídios e principalmente a tarifa feed-in, que atende em melhores condições diretrizes relevantes como a redução dos impactos ambientais, o desenvolvimento tecnológico nacional, a estabilidade de mercado e a ampliação de fontes limpas na matriz elétrica. Por fim, foi feita uma análise econômica de distintas fontes renováveis em condições variadas de mercado como taxa de retorno, custo de transmissão, crédito de carbono e outros. Desta forma foi possível avaliar as melhores e piores condições de formação de preço final por tecnologia (eólica, biomassa e PCHs) para 
implementação de uma comercializadora de energia. Neste estudo, foi possível avaliar o impacto da tarifa de transmissão assim como a sensibilidade do preço final da energia em relação à eventual flutuação do câmbio, para energias com maior parte de componentes precificados em moeda estrangeira. $O$ trabalho conclui que a viabilização de uma comercializadora de energia renovável no pais depende fundamentalmente de um marco regulatório estável, uma política financeira e fiscal de longo prazo e um modelo de mercado aberto.

Palavras-chave: Energias Renováveis; Tarifas Feed in; Leilões de Energia; Subsídios; Comercialização de Energia; Modelos de Mercado 


\section{ABSTRACT}

Renewable energy plays a key role as part of the solutions to the climate change crisis. However, the potential for new renewable energy is underdeveloped in Brazil. This dissertation presents the necessary arguments to promote the development of the commercialization of new renewable energy sources within the political-strategic, socio-environmental and economic-financial aspects for the implementation of a mature national market.

Environmental, social and technical justification is used to enhance the expansion of electric energy generation from renewable sources such as wind, biomass, solar and small hydropower. The important role of tariff policy, the current model of the energy sector and the impact of taxes and fees in both rural and urban areas was also addressed in the text. A scenario is presented indicating the potential share of renewable energies in the electric matrix of the country and its expansion potential. The scenario emphasizes the decentralization and diversification of the energy matrix as well as promotes equitable justice and decouples the economic growth from new energy generation. A wide number of electricity trading markets were discussed and the competitive retail one was identified as the most suitable for the commercialization of new renewable energy sources. The most interesting elements of a number of case studies in Europe, Asia and US were analyzed to contribute to the discussion of a regulatory framework to develop a renewable energy market in Brazil. Among them the quota system; the auction system; the subsidies and finally the feed-in system that better addresses the reduction of environmental impact, national technology development, market stability and the expansion of renewable sources in the electricity matrix.

Finally, an economic analysis of different renewable technologies (wind, biomass, small hydro) was deployed varying the return of investment rate, the grid cost, the carbon credits and others. The economic simulation set a price range with the best and worst conditions per technology for consideration in the commercialization of renewable energy. In this study it was possible to evaluate the impact of the grid fee or the exchange rate for technologies with many imported components. The work concludes that the feasibility of the commercialization of renewable energy in the 
country relies mainly on a stable regulatory framework, a financial and fiscal long term policy and an open energy market model.

Key-words: Renewable Energy; Feed in Tariff; Energy Auctions; Subsidies; Energy Commercialization; Market Models 


\section{LISTA DE TABELAS}

Tabela 2.4.1 - Oferta Interna de Energia por Participação de Energético................ 25

Tabela 2.4.2 - Comparativo das Emissões de CO2 entre Brasil e Mundo ............... 25

Tabela 2.4.3 - Comparativo da Oferta Interna de Energia 2008/2009.................. 26

Tabela 3.4.1 - Encargos e Tributos Aplicados ao Setor Elétrico ........................... 42

Tabela 3.4.3 - Impactos Econômicos dos Preços de Energia ................................. 45

Tabela 7.4.1 - Resultados Parciais do Proinfa .................................................. 86

Tabela 7.6.1 - Tarifas Propostas no PL 630/03 .................................................. 95

Tabela 8.3.1 - Resultados da simulação para Energia Eólica em R\$/MWh para os Distintos Cenários Simulados................................................................... 102

Tabela 8.4.1 Resultados da simulação para Energia de $\mathrm{PCH}$ em $\mathrm{R} \$ / \mathrm{MWh}$ para os Distintos Cenários Simulados................................................................ 104

Tabela 8.5.1 - Comparação do Preço da Energia de Biomassa com Distintos Cenários de Simulação .................................................................................. 105 


\section{LISTA DE FIGURAS}

Figura 2.4.1 - Evolução da Participação de Fontes Renováveis na Oferta Interna de Energia

Figura 2.5.1 - Potencial Hidroelétrico Explorado e Potencial por Região................. 27

Figura 2.5.2 - Sistema de Transmissão Brasil .................................................. 29

Figura 3.4.1 - Crescimento Percentual de Indicadores Econômicos ........................ 36

Figura 3.4.2 - Comparativo de Indicadores Econômicos IGPM e IPCA com Tarifa Industrial Média de Energia

Figura 3.4.3 - Consumo de Energia na Região Sudeste/Centro Oeste no Período $2007 / 2008 / 2009$

Figura 3.4.4 - Consumo de Energia Elétrica na Região Sul no Período 2007/2008/2009 40

Figura 3.4.5 - Carga Consolidada de Tributos e Encargos 43

Figura 3.4.6 - Escalada da Tarifa Devido aos Encargos e Tributos 44

Figura 3.4.7 - Estudos Comparativos da Carga Tributária no Setor Elétrico. 44

Figura 4.3.1 - Geração Elétrica Total - Cenário de Referência 2005 53

Figura 4.3.2 - Geração Elétrica Total - Cenário de Referência 2050 54

Figura 4.3.3 - Geração Elétrica Total - Cenário [R]evolução Energética 2050........ 55

Figura 4.3.4 - Custos Totais de Geração de Eletricidade. 56

Figura 4.3.5 - Emissão de Carbono Cenário Referência e Cenário [R]evolução Energética 57

Figura 5.3.1 - Modelo de Comprador Único 62

Figura 5.4.1 - Modelo de Competição no Atacado . 63

Figura 5.4.2 - Modelo de Competição no Atacado com Agente Comprador .... 63

Figura 5.5.1 - Modelo Competição no Varejo . 65

Figura 5.6.1 - Cronologias das Reformas no Setor Elétrico 66

Figura 5.6.2 - Mercado Elegível na Europa para Livre Competição na Eletricidade 67

Figura 8.3.1 - Curva Comparativa de Preço da Energia Eólica em $\mathrm{R} \$ / \mathrm{MWh}$ para os Distintos Cenários Simulados. 103 
Figura 8.4.1 - Comparação do Preço da Energia de PCH com os Distintos Cenários Simulados 104

Figura 8.5.1 - Comparação do Preço da Energia de Biomassa com os Distintos Cenários Simulados 106 


\section{LISTA DE SIGLAS E ABREVIATURAS}

ABEEÓLICA Associação Brasileira de Energia Eólica

ABRACE

Associação Brasileira de Grandes Consumidores Industrial de Energia e de Consumidores Livres

ABRADEE

ACL

Associação Brasileira de Distribuidoras de Energia Elétrica

ACR

Ambiente de Comercialização Livre

AIAA

Ambiente de Comercialização Regulado

AMCHAM

Associação das Indústrias de Açúcar e Álcool

ANEEL

Câmara Americana de Comércio Brasil - Estados Unidos

APMPE

ARRA

Agência Nacional de Energia Elétrica

BEN

Associação de Pequenos e Médios Produtores de Energia

American Recovery and Reinvestment Act

BNDES

Balanço Energético Nacional

CCC

Banco Nacional de Desenvolvimento Econômico e Social

CCEE

Conta de Consumo de Combustíveis

CDE

Câmara de Comercialização de Energia Elétrica

CEEE-RS

Conta de Desenvolvimento Energético

CELESC

Companhia Estadual de Energia Elétrica do Rio Grande do Sul

CEMAT

Centrais Elétricas de Santa Catarina

CEMIG

Centrais Elétricas Matogrossenses S/A

CEPISA

Companhia Energética de Minas Gerais

CERON

Eletrobrás Distribuição Piauí

CESP

Eletrobrás Distribuição Rondônia

CHESF

Companhia Energética de São Paulo

CIP

Eletrobrás Companhia Hidroelétrica do São Francisco

$\mathrm{CO} 2$

Contribuição para a lluminação Pública

Dióxido de Carbono

COELBA

Companhia de Eletricidade do Estado da Bahia

CONFINS

Contribuição Social para o Financiamento da Seguridade Social

COPEL Companhia Paranaense de Energia

COSERN

Companhia Energética do Rio Grande do Norte 


\begin{tabular}{|c|c|}
\hline CPFL & Companhia Paulista de Força e Luz \\
\hline CPMF & Contribuição Provisória sobre Movimentação Financeira \\
\hline CSLL & Contribuição Social sobre o Lucro Líquido \\
\hline ECE & Encargo de Capacidade Emergencial \\
\hline ELEKTRO & Elektro Eletricidade e Serviços S/A \\
\hline ELETROBRÁS & Centrais Elétricas Brasileiras S/A \\
\hline ELETRONORTE & Centrais Elétricas do Norte do Brasil S/A \\
\hline ENERSUL & Empresa Energética do Mato Grosso do Sul \\
\hline EPC & Engineering, Procurement and Construction Contracts \\
\hline EPE & Empresa de Pesquisa Energética \\
\hline EREC & European Renewable Energy Council \\
\hline EUA & Estados Unidos da America \\
\hline FERC & Federal Energy Regulatory Commission \\
\hline FGV & Fundação Getúlio Vargas \\
\hline FURNAS & Eletrobrás Furnas \\
\hline GEE & Gases de Efeito Estufa \\
\hline GEPEA & $\begin{array}{l}\text { Grupo de Energia do Departamento de Energia e Automação } \\
\text { Elétrica da Universidade de São Paulo }\end{array}$ \\
\hline GN & Gás Natural \\
\hline GREENPEACE & Associação Civil Greenpeace. \\
\hline GT-GDS & $\begin{array}{l}\text { Grupo de Trabalho de Geração Distribuída com Sistemas } \\
\text { Fotovoltaicos }\end{array}$ \\
\hline GWEC & Global Wind Energy Council \\
\hline IBGE & Instituto Brasileiro de Geografia e Estatística \\
\hline ICB & Índice de Custo Benefício \\
\hline ICMS & Imposto sobre a Circulação de Mercadorias e Serviços \\
\hline IGPM & Índice Geral de Preços do Mercado - Fundação Getúlio Vargas \\
\hline IPC & $\begin{array}{l}\text { Índice de Preços ao Consumidor - Fundação Instituto de } \\
\text { Pesquisas Econômicas }\end{array}$ \\
\hline IPCA & $\begin{array}{l}\text { Índice Nacional de Preços ao Consumidor Ampliado - Instituto } \\
\text { Brasileiro de Geografia e Estatística }\end{array}$ \\
\hline IPCC & Intergovernmental Panel for Climate Change \\
\hline ISO & Interim Standard Offer \\
\hline
\end{tabular}




\begin{tabular}{|c|c|}
\hline ISSQN & Imposto sobre Serviços de Qualquer Natureza \\
\hline MAE & Mercado Atacadista de Energia \\
\hline MCT & Ministério da Ciência e Tecnologia \\
\hline MME & Ministério de Minas e Energia \\
\hline NFFO & Non-Fossil Fuel Obligation \\
\hline OIEE & Oferta Interna de Energia Elétrica \\
\hline ONS & Operador Nacional do Sistema \\
\hline ONU & Organização das Nações Unidas \\
\hline PASEP & Programa de Formação do Patrimônio do Servidor Público \\
\hline $\mathrm{PCH}$ & Pequena Central Hidroelétrica \\
\hline PCT & Pequena Central Térmica (com uso de biomassa) \\
\hline PIB & Produto Interno Bruto \\
\hline PIS & Programa de Integração Social \\
\hline PLD & Preço de Liquidação de Diferenças \\
\hline PPA & Power Purchase Agreement \\
\hline PRODEEM & $\begin{array}{l}\text { Programa de Desenvolvimento Energético dos Estados e } \\
\text { Municípios }\end{array}$ \\
\hline PROINFA & Programa de Incentivo às Fontes Alternativas de Energia Elétrica \\
\hline PTC & Production Tax Credits \\
\hline PUC & Public Utility Comission \\
\hline PURPA & The Public Utility Regulatory Policies Act \\
\hline RESEB & Reestruturação Setor Elétrico Brasileiro \\
\hline RGR & Reserva Global de Reversão \\
\hline RO & Renewables Obligation \\
\hline RPS & Renewable Portfolio Standard \\
\hline RTE & Reajuste Tarifário Extraordinário \\
\hline SELIC & $\begin{array}{l}\text { Sistema Especial de Liquidação e de Custódia - Banco Central do } \\
\text { Brasil }\end{array}$ \\
\hline SIN & Sistema Interligado Nacional \\
\hline TUSD & Tarifa de Uso do Sistema de Distribuição \\
\hline TUST & Tarifa de Uso do Sistema de Transmissão \\
\hline UBP & Uso de Bem Público \\
\hline UNICA & União da Indústria de Cana de Açúcar \\
\hline
\end{tabular}




\section{SUMÁRIO}

CAPÍTULO 1 - INTRODUÇÃO

CAPÍTULO 2- GERAÇÃO DE ENERGIA NO CENÁRIO DE MUDANÇAS CLIMÁTICAS

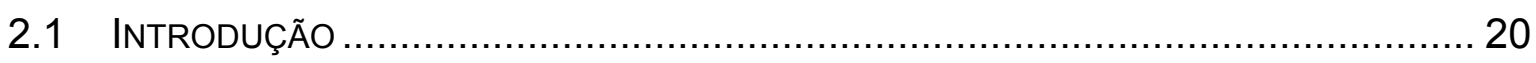

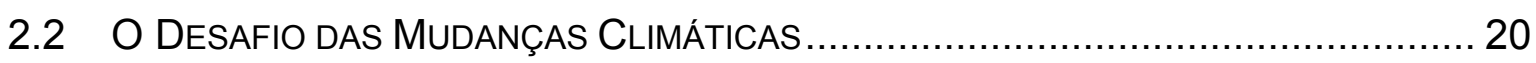

2.3 Aumento da PaRticipaçÃo de Combustíveis fósseis Versus Energias RENOVÁVEIS 22

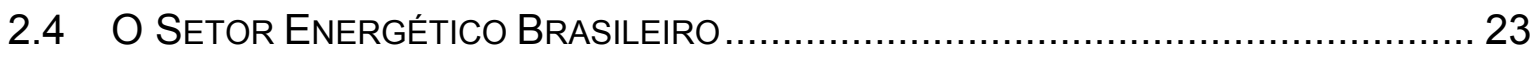

2.5 O SETOR ELÉTRICO BRASILEIRO …………………................................ 27

CAPÍTULO 3 - MODELO INSTITUCIONAL DO SETOR ELÉTRICO E A POLITICA

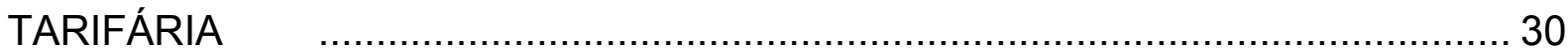

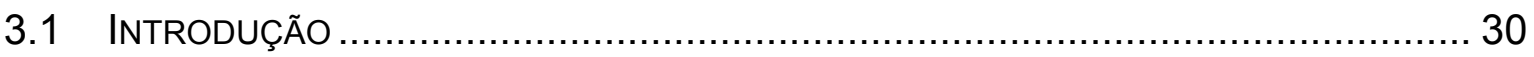

3.2 AÇões Político-EConômicas e TARIFAS no Setor ElÉtrico BRAsileiro ..... 30

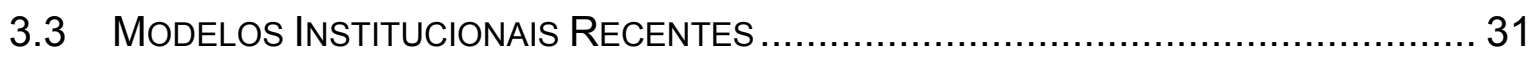

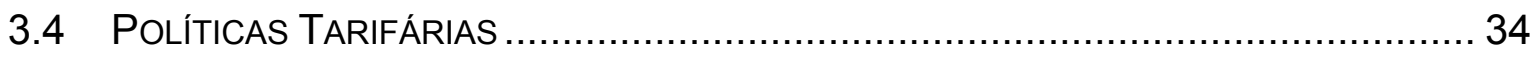

CAPÍTULO 4- REVOLUÇÃO ENERGÉTICA PARA UMA NOVA MATRIZ

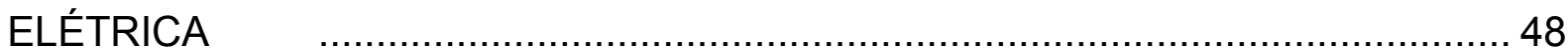

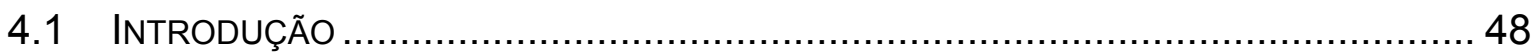

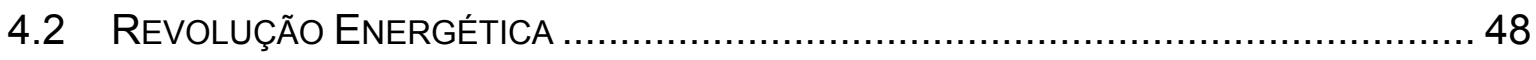

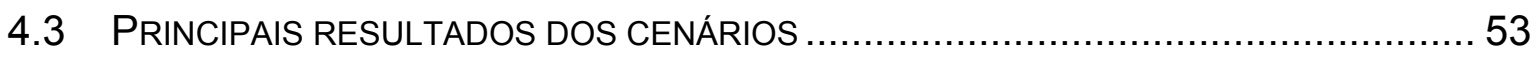

4.4 DiRECIONADORES PARA A (R)EVolUÇÃo ENERGÉtICA ....................................57

CAPÍTULO 5- MODELOS DE MERCADO PARA COMERCIALIZAÇÃO DE ENERGIA

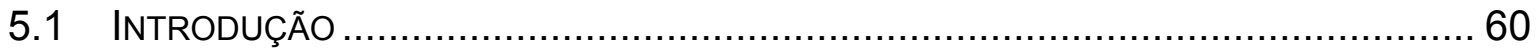

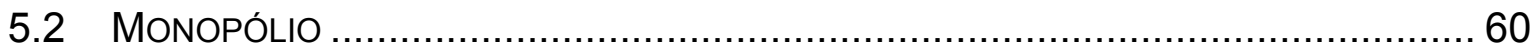

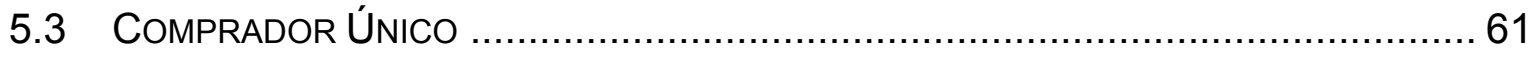

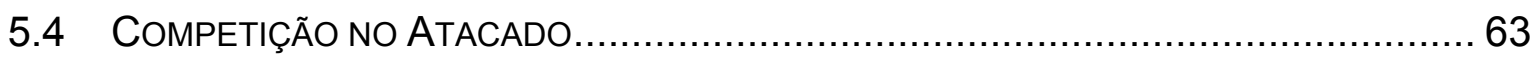

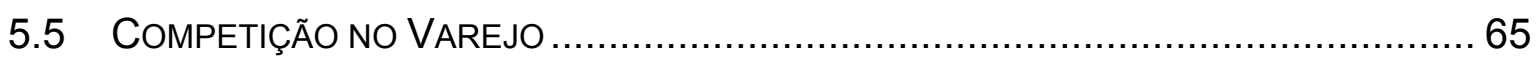

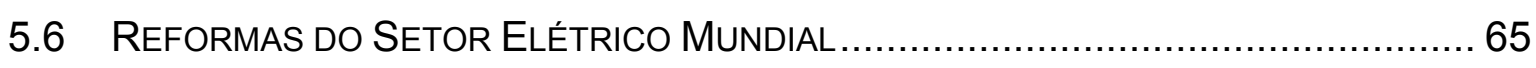


CAPITULO 6 - EXPERIÊNCIAS INTERNACIONAIS NA COMERCIALIZAÇÃO DE

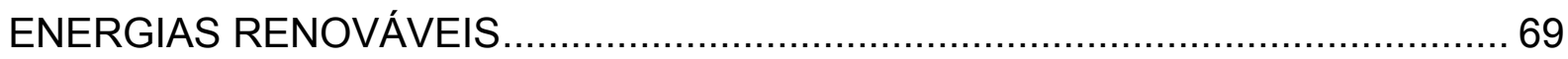

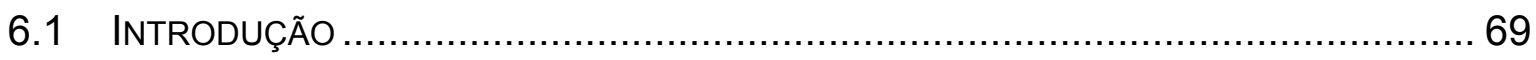

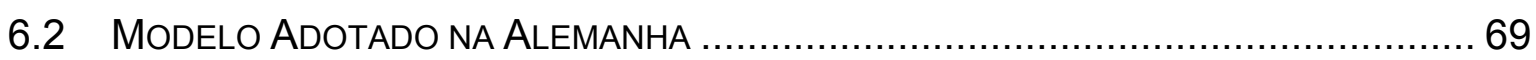

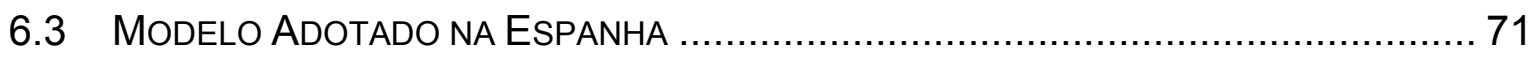

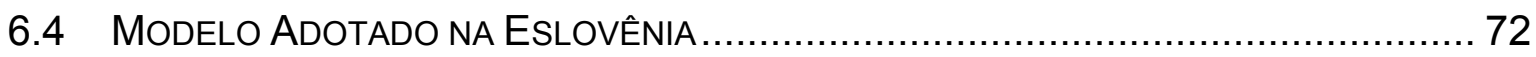

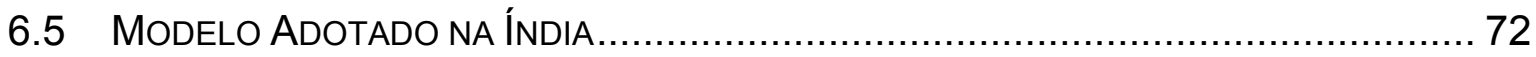

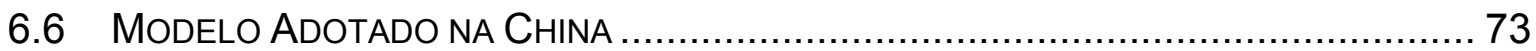

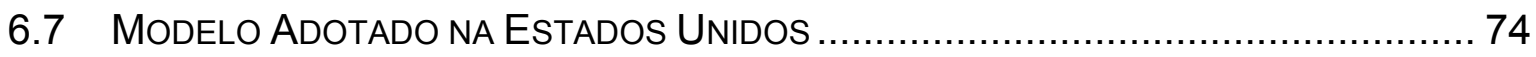

6.8 Modelo AdotAdo NA REINo UNIDO ……………................................. 76

CAPÍTULO 7 - NOVO MARCO REGULATÓRIO PARA PROMOVER AS NOVAS FONTES DE ENERGIAS RENOVÁVEIS NO BRASIL ........................................... 78

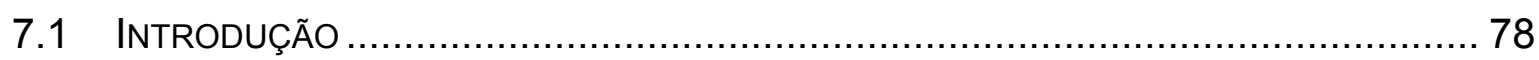

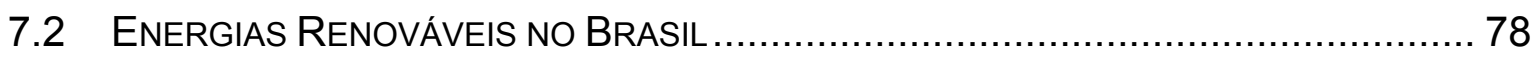

7.3 Modelos de Políticas de Desenvolvimento de Fontes Renováveis........... 81

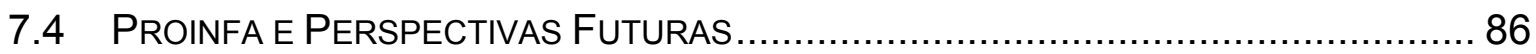

7.5 LeILÕES DE RENOVÁVEIS E PERSPECTIVAS FutURAS ..................................... 89

7.6 Nova Política Pública de incentivo a Novas Fontes de Energias RENOVÁVEIS NO BRASIL - PL 630/03..................................................................... 94

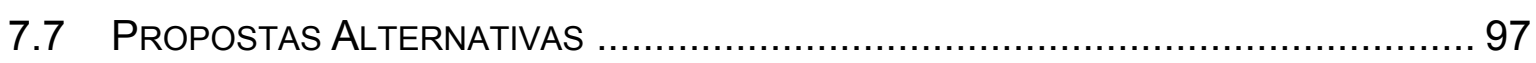

CAPÍTULO 8 - ESTUDO DE VIABILIDADE ECONÔMICA DAS NFER COM ANÁLISE DO PREÇO POR TECNOLOGIA .......................................................... 100

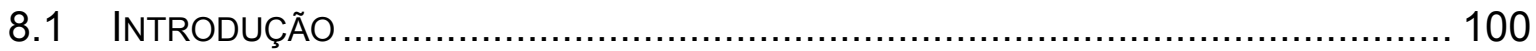

8.2 PREMISSAS ADOTADAS PARA ESTUDO DE VIABILIDADE ECONÔMICA .................... 100

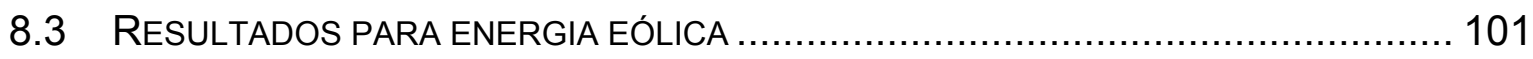

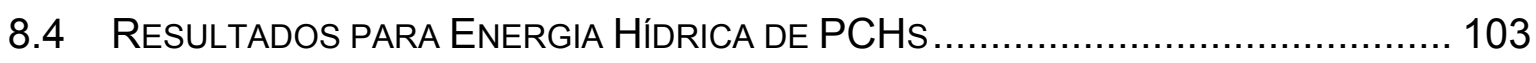

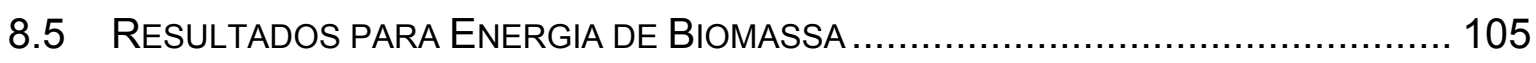

CAPÍTULO 9 - COMERCIALIZAÇÃO DE NOVAS FONTES DE ENERGIAS

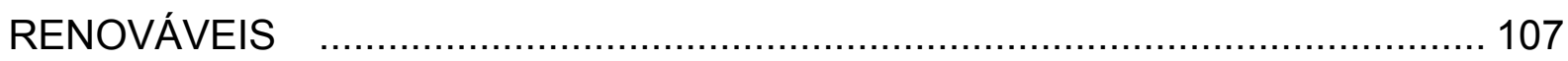

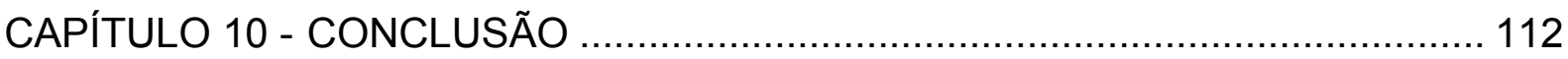




\section{CAPÍTULO 1 - INTRODUÇÃO}

As novas fontes de energias renováveis tem um papel fundamental no enfrentamento da crise das mudanças climáticas. O aumento das emissões de gases de efeito estufa (GEE), o aumento populacional, o crescimento da economia brasileira e a demanda de energia requerem a necessidade de um novo modelo de desenvolvimento socioeconômico. Ao não desenvolver significativamente o expressivo potencial nacional das novas fontes de energias renováveis (NFER) como solar, eólica, PCHs e de biomassa, o plano brasileiro de expansão da geração de energia poderá contribuir para o aumento das emissões de GEE e para o agravamento dos impactos de eventos climáticos extremos.

Este trabalho visa apresentar argumentos político-estratégicos e simulação econômico-financeira para justificar a viabilidade da comercialização de NFER e consequentemente, o estabelecimento de um mercado nacional maduro para as mesmas.

O Brasil está em posição estratégica para diversificar e descentralizar sua matriz elétrica a partir de fontes renováveis. As conclusões da avaliação de oportunidades relatadas neste trabalho visam contribuir para a tomada de decisões de lideranças nacionais e motivar os consumidores brasileiros para que haja uma ampliação do mercado e maior interesse na comercialização dessas fontes.

Os argumentos são baseados em estudos, relatórios do próprio autor em cooperação com especialistas, e contribuição de outros autores. Os argumentos são adicionados à simulação econômico-financeira elaborada dentro da realidade competitiva deste mercado, para demonstrar que, por meio da comercialização de energia renovável, é possível criar um mercado estável de energia limpa que poderá colaborar na expansão de uma matriz energética de baixa emissão de carbono no Brasil.

Historicamente, o setor energético brasileiro privilegiou as fontes hídricotérmicas e o plano atual do governo federal orienta-se para a expansão da geração de energia e prevê novas usinas térmicas (principalmente a óleo combustível, carvão e gás natural) e a implantação de grandes hidroelétricas, especialmente no bioma Amazônico. 
As decisões tomadas por governos de países que adotaram o uso de novas fontes de energias renováveis revelam que a oportunidade requer um marco regulatório específico e investimentos, a fim de garantir a compra de toda a energia gerada e a inserção dessas fontes na rede elétrica.

$\mathrm{Na}$ falta de uma política pública orientada a ampliar a participação das novas fontes de energias renováveis, o papel dos consumidores - individuais e corporativos - é de grande importância para fomentar a demanda por energias renováveis oferecidas por comercializadoras independentes.

Os argumentos levantados neste estudo abordam a política tarifária, modelos de mercado, mecanismos especiais para a geração e comercialização de novas fontes de energias renováveis, no Brasil. O estudo está elaborado no contexto das mudanças climáticas, que apontam para a reflexão sobre o modelo de desenvolvimento baseado no uso de energias fósseis e liberação crescente de gases de efeito estufa (GEE) e, de outro lado, nas vantagens ambientais, sociais e competitivas das novas fontes de energias renováveis.

O estudo apresenta uma análise internacional de distintas experiências adotadas principalmente na Europa e nos Estados Unidos para o fomento das energias renováveis na matriz energética. A análise do setor energético brasileiro incluindo tarifa e marco regulatório mostra a íntima relação das decisões governamentais na definição de marcos regulatórios e orientação para investimentos financeiros.

O Brasil está em pleno desenvolvimento e está, portanto, expandindo anualmente seu parque gerador de energia, o que oferece uma oportunidade para um aumento na inserção das novas fontes energéticas renováveis em sua matriz elétrica. Este trabalho tem como objetivo fazer uma revisão da estrutura e funcionamento do setor elétrico brasileiro, do ponto de vista histórico e de desempenho, a fim de demonstrar as oportunidades para o aumento da participação de novas fontes de energias renováveis e sua comercialização independente através do mecanismo de feed-in. Para atingir os objetivos propostos a dissertação é composta pelos seguintes capítulos:

- Capítulo 1: Introdução

- Capítulo 2: Geração de Energia no Cenário de Mudanças Climáticas discute a contribuição do setor energético tanto no agravamento como 
na solução da crise climática e apresenta o histórico recente do setor elétrico.

- Capítulo 3: O Modelo do Setor Elétrico e a Política Tarifária - discute o histórico das políticas tarifárias, modelos institucionais mais recentes e o impacto dos encargos na sua composição.

- Capítulo 4: Revolução Energética uma Nova Matriz Elétrica para o Brasil - apresenta um cenário referência para a matriz elétrica Brasileira até 2050 com dois cenários comparativos (governo federal e da sociedade civil)

- Capítulo 5: Modelos de Mercado para a Comercialização de Energia discute as distintas arquiteturas de mercado para organizar as relações entre geração, comercialização e distribuição.

- Capítulo 6: Experiências Internacionais na Comercialização de Novas fontes de energias renováveis - analisa modelos de mercado adotados em vários países para aumentar a participação das NFER .

- Capítulo 7: Novo Marco Regulatório para Promover as Novas Fontes de Energias Renováveis - apresenta o histórico das energias renováveis no Brasil e discute os principais elementos de um marco regulatório ideal.

- Capítulo 8: Estudo de Viabilidade Econômica das NFER com Análise do Preço por Tecnologia - apresenta o estudo de sensibilidade do preço final da energia por fonte (eólica, PCH e Biomassa) com a variação das condições econômicas.

- Capítulo 9: Comercialização de Novas fontes de energias renováveis apresenta as diretrizes para viabilizar a comercialização de energias renováveis no Brasil como marco regulatório apropriado; preço final da energia competitivo; política pública; condições apropriadas de financiamento e tarifa e a valorização dos ganhos sócio-ambientais.

- Capítulo 10: Conclusão - Apresenta as conclusões da avaliação das oportunidades de comercialização de NFER no Brasil. 


\section{CAPÍTULO 2 - GERAÇÃO DE ENERGIA NO CENÁRIO DE MUDANÇAS CLIMÁTICAS}

\subsection{INTRODUÇÃO}

Este capítulo apresenta as principais evidências que relacionam o setor energético com $\mathrm{o}$ fenômeno das mudanças climáticas e aponta a grande contribuição que as novas fontes de energias renováveis podem ter no combate ao aquecimento global. O contexto climático exige a redução da geração de energia elétrica a partir de fontes fósseis, favorecendo o aumento da comercialização de novas fontes de energias renováveis no Brasil. Este capítulo também apresenta o atual setor energético e elétrico nacional, as principais características do sistema elétrico interligado nacional e o desafio da manutenção de um forte componente renovável na matriz para garantir a redução das emissões de GEE no país.

\subsection{O DESAFIO DAS MUdANÇAS CLIMÁtICAS}

Os dados revelados no quarto relatório do Painel Intergovernamental de Mudanças Climáticas (IPCC, 2007) e as informações divulgadas no relatório do Greenpeace Brasil "Mudanças do Clima Mudanças de Vida (Greenpeace, 2006) destacam os seguintes aspectos:

- A sociedade mundial terá que tomar atitude apropriada entre optar pela sustentabilidade dos recursos naturais - submetidos a pressões globais para aumento do consumo - ou continuar adotando o crescimento econômico, a qualquer preço, em relação à reposição dos estoques de capital natural e comprometimento dos serviços ambientais. 
- As mudanças climáticas se destacam nas agendas políticas, no Brasil e em todas as partes do mundo, por conta da previsão de graves conseqüências de caráter econômico, social e ambiental.

- Entre tantas causas do aquecimento global, não há mais dúvidas quanto à responsabilidade dos humanos pela vulnerabilidade do Planeta e a óbvia necessidade de ações político-estratégicas, tecnológicas e financeiras para redução das emissões de GEE (IPCC, 2007)

- Não há dúvidas de que as principais fontes de emissões estão nos países industrializados, do hemisfério norte, os quais consomem mais do que $70 \%$ da energia produzida e de que os EUA, sozinho, é responsável por cerca de $25 \%$ das emissões mundiais de GEE. Nestes países, os combustíveis fósseis - carvão, petróleo e gás natural respondem por $70 \%$ das emissões. (IPCC, 2007)

- Os restantes $30 \%$ de emissões globais procedem dos países em desenvolvimento, com destaque especial para a China e o Brasil. (IPCC, 2007)

Portanto, é preciso considerar o comportamento público-político, o modelo energético e o modelo de desenvolvimento industrial existente no Brasil, diante das evidências provocadas pelos GEE.

Segundo os dados preliminares da segunda comunicação nacional das emissões brasileiras de gases de efeito estufa feita para Convenção do Clima pelo Ministério de Ciência e Tecnologia do Governo do Brasil com ano base 2005, 76,3\% das emissões de GEE são causadas, no Brasil, por mudança no uso da terra e florestas. O setor energético é responsável por outros $22 \%$ e a indústria completa os $1,6 \%$ restantes. Ações objetivas, para redução significativa das emissões de GEE deverão ser focadas na redução do desmatamento; no aumento da participação das novas fontes de energias renováveis na matriz energética; na ampliação de programas de eficiência energética; e na redução do uso de combustíveis fósseis. 


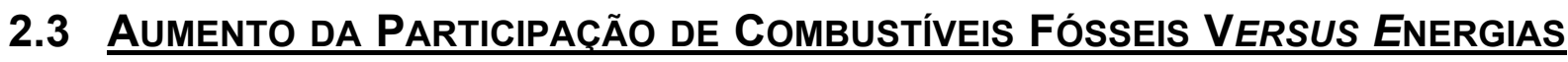 RENOVÁVEIS}

As políticas públicas e as respostas dos investidores, nos países de economia desenvolvida, estão sinalizando, claramente, para uma transição do uso de fontes fósseis, para outras consideradas "limpas". O Brasil possui uma matriz elétrica majoritariamente limpa com a participação de $89,8 \%$ (BEN, 2010) de energias renováveis. Entretanto, quando se analisa o cenário de expansão energética da matriz elétrica brasileira proposta pelo Planejamento Nacional Energético 2030, elaborado pela Empresa de Pesquisa Energética (EPE), nota-se que em termos percentuais haverá aumento de geração de eletricidade por combustível fóssil e nuclear e uma diminuição da participação de energias renováveis na matriz energética. Esta tendência começa a ser corrigida no Plano Decenal de Expansão de Energia 2010-2019, no qual a contribuição das termoelétricas movidas a combustíveis fósseis foi revista de 14 mil MW de capacidade instalada (PDE, 2008) para 9 mil MW com usinas a serem construídas até o prazo limite de 2014. Com estes resultados o crescimento das térmicas a carvão atinge $80 \%$ e o de óleo combustível atinge $170 \%$.

Portanto, ainda podemos afirmar que apesar da maior participação das energias renováveis no plano decenal 2010-2019, o planejamento foi extremamente conservador em relação ao potencial das NFER, a exemplo da biomassa que chegaria a $8.500 \mathrm{MW}$ e a eólica que atingiria $6.000 \mathrm{MW}$, em ambos os casos números muito aquém do potencial de geração destas fontes.

As NFER podem oferecer múltiplas vantagens competitivas e comparativas ao planejamento nacional.

- Reservas tecnicamente acessíveis

- Potencial de atendimento ao consumo brasileiro, com complementaridade.

- Ampla gama de opções: energia eólica, biomassa, energia solar fotovoltaica e térmica, energia oceânica e a própria hidrelétrica. 
- Tecnologias em processo de desenvolvimento aprimorado com baixa emissão de gases de efeito estufa, a partir de fontes naturais virtualmente inesgotáveis.

- Importante potencial para inovação e desenvolvimento tecnológico, com geração de emprego e uso de recursos humanos qualificados.

- Possibilidade de aumento de receita através do mercado de créditos de carbono e principalmente de maiores investimentos em tecnologias renováveis.

Somados a estas vantagens, a eficiência energética e o gerenciamento pelo lado da oferta e demanda - nos seus aspectos, objetivos e possibilidades mais amplos - fazem parte de uma estratégia adotada praticamente em todos países do mundo e constituem a abordagem das organizações focadas em práticas de ecoeficiência (econômica-ambiental) e sustentabilidade (econômica, ambiental e social). A adoção de tais práticas, associadas à utilização de novas fontes de energias renováveis, representa a potencialização de iniciativas para prevenção de aquecimento global e aperfeiçoamento de processos produtivos.

A corrida mundial por recursos naturais, principalmente energia, obriga a sociedade a enfrentar o dilema: sustentabilidade ou desenvolvimento econômico a qualquer preço? Ao mesmo tempo, o aquecimento global e seus impactos sócioambientais e financeiros ocupam cada vez mais espaço na agenda política nacional e internacional.

\subsection{O SETOR ENERGÉTICO BRASILEIRO}

A matriz energética nacional é caracterizada pela oferta de fontes renováveis e não renováveis de energia, respectivamente $47,3 \%$ e $52,7 \%$ no ano de 2009 , conforme informações oficiais constantes no Balanço Energético Nacional de 2010 (BEN, 2010) e apresentadas na Figura 2.4.1, que mostra a evolução da participação de fontes renováveis na oferta interna de energia nos últimos trinta anos. Observando estes números, podemos notar uma redução na participação das energias renováveis a partir dos anos 90 . 
A Tabela 2.4.1 apresenta a participação dos principais energéticos na matriz energética nos anos 2008 e 2009. Verifica-se que o petróleo, produtos da cana-deaçúcar e energia hidráulica e eletricidade apresentaram aumento na oferta interna de energia em relação ao ano anterior. O petróleo, maior fonte não-renovável, representa $37,8 \%$ do total da oferta de energia, enquanto os produtos da cana de açúcar representam 18,1\% e a energia hidráulica e a eletricidade representam 15,3\%. Todas as outras fontes, gás natural, carvão, urânio, e lenha apresentaram redução na participação como conseqüência da desaceleração econômica observada em 2009. 
Tabela 2.4.1 - Oferta Interna de Energia por Participação de Energético Oferta Interna de Energia

\begin{tabular}{lrr} 
Energia não Renovável & $52,7 \%$ & $54,1 \%$ \\
\hline Petróleo e Derivados & $37,8 \%$ & $36,6 \%$ \\
Gás Natural & $8,7 \%$ & $10,3 \%$ \\
Carvão Mineral e Derivados & $4,8 \%$ & $5,8 \%$ \\
Urânio $\left(\mathrm{U}_{3} \mathrm{O}_{8}\right)$ e Derivados & $1,4 \%$ & $1,5 \%$ \\
\hline Energia Renovável & $47,3 \%$ & $45,9 \%$ \\
\hline Produtos da Cana-de-açúcar & $18,1 \%$ & $17,0 \%$ \\
Energia Hidráulica e Eletricidade & $15,3 \%$ & $14,0 \%$ \\
Lenha e Carvão Vegetal & $10,1 \%$ & $11,6 \%$ \\
Outras Renováveis & $3,8 \%$ & $3,4 \%$ \\
\hline
\end{tabular}

Fonte:BEN 2010

A Tabela 2.4.2 apresenta uma análise comparativa das emissões de $\mathrm{CO} 2$ da matriz energética brasileira em comparação com a matriz mundial, latino americana e dos EUA no ano de 2007. Analisando estes indicadores de emissões por habitante ou por oferta interna de energia, podemos verificar que as emissões de $\mathrm{CO} 2$ da matriz energética brasileira ainda são baixas se comparadas com outros países e regiões. Este perfil pode mudar rapidamente com o aumento da participação das fontes fósseis na matriz e em particular com a expansão da participação do petróleo na matriz nacional em função da descoberta de novas reservas de grande porte em águas profundas no pré-sal.

Tabela 2.4.2 - Comparativo das Emissões de CO2 entre Brasil e Mundo Emissões de $\mathrm{CO}_{2}$ (ano base 2007)

\begin{tabular}{lccccc} 
Indicador & Brasil & EUA & Japão & $\begin{array}{c}\text { América } \\
\text { Latina }\end{array}$ & Mundo \\
\hline $\mathrm{t} \mathrm{CO}_{2} / \mathrm{hab}$ & 1,78 & 19,00 & 9,49 & 2,14 & 4,28 \\
$\mathrm{t} \mathrm{CO}_{2} /$ tep OIE & 1,48 & 2,45 & 2,30 & 1,83 & 2,39 \\
$\mathrm{t} \mathrm{CO}_{2} / 10^{3}$ US $\$$ de PIB 1 & 0,43 & 0,50 & 0,24 & 0,52 & 0,73 \\
$\mathrm{t} \mathrm{CO}_{2} / \mathrm{km}^{2}$ de superfície & 41 & 630 & 3.299 & 48 & 140 \\
\hline
\end{tabular}

Nota: ${ }^{1}$ US\$ em valores correntes de 2000

Fonte: Agência Internacional de Energia (IEA) 
Segundo a Tabela 2.4.3 Oferta Interna de Energia (BEN, 2010), verificamos que a comparação dos dados no período 2008-2009 indica que a oferta interna de energia em 2009 reduziu em 3,4\% apesar da pequena retração de 0,2\% ( $R$ \$ 3,143 trilhões) do Produto Interno Bruto no período (IBGE, 2010). O consumo final de energia sofreu uma redução de $2,7 \%$, e o setor industrial contribuiu com a maior parcela de redução com $6,7 \%$. Estes números apontam para o impacto da crise econômica no setor energético neste período. Houve uma redução na oferta interna de energia de carvão mineral e derivados de mais de $19,4 \%$, com impacto direto nas emissões de $\mathrm{CO} 2$ da matriz energética. Vale destacar que com menor participação das fontes fósseis na oferta interna de energia as emissões totais de $\mathrm{CO} 2$ diminuíram $6,2 \%$ em relação a 2008 . A fonte renovável com maior crescimento foi a hidroelétrica, com $5,2 \%$, beneficiada pela condição hidrológica favorável no período.

Tabela 2.4.3 - Comparativo da Oferta Interna de Energia 2008/2009

Oferta Interna de Energia

Milhões de tep

\begin{tabular}{lccc} 
& 2009 & 2008 & $\triangle \%$ \\
Oferta Total & 243,9 & 252,6 & $-3,4 \%$ \\
\hline Energia não Renovável & 128,6 & 136,6 & $-5,9 \%$ \\
\hline Petróleo e Derivados & 92,1 & 92,4 & $-0,3 \%$ \\
Gás Natural & 21,3 & 25,9 & $-17,7 \%$ \\
Carvão Mineral e Derivados & 11,7 & 14,6 & $-19,4 \%$ \\
Urânio $\left(\cup_{3} O_{8}\right)$ e Derivados & 3,4 & 3,7 & $-7,6 \%$ \\
\hline Energia Renovável & 115,3 & 116,0 & $-0,6 \%$ \\
\hline Energia Hidráulica e Eletricidade & 37,3 & 35,4 & $5,2 \%$ \\
Lenha e Carvão Vegetal & 24,6 & 29,2 & $-15,8 \%$ \\
Produtos da Cana-de-açúcar & 44,1 & 42,9 & $2,8 \%$ \\
Outras Renováveis & 9,3 & 8,5 & $10,2 \%$ \\
\hline
\end{tabular}




\subsection{O SETOR ELÉTRICO BRASILEIRO}

Segundo o Banco de Informação de Geração - BIG (ANEEL, 2010) o Brasil possui no momento um total de 2.271 empreendimentos em operação, gerando 110 GW de potência, sendo $68 \%$ hidroelétrica; $16 \%$ térmica gás, carvão e óleo; $2 \%$ nuclear, $6 \%$ biomassa, $1 \%$ eólica, $7 \%$ importada. A oferta interna de energia elétrica (OIEE) em 2009 foi de 509,5 TWh e apresentou um crescimento de 0,6\% em relação ao ano anterior (BEN, 2010).

O setor elétrico possui predominância de produção de energia a partir de usinas hidráulicas (ONS, 2009). Apenas $25 \%$ do potencial hidráulico brasileiro foi explorado, no entanto o maior potencial remanescente está concentrado principalmente na região Amazônica, o que certamente deverá ampliar o risco ambiental destes empreendimentos. A figura 2.5.1 compara o potencial hidroelétrico nacional com o que já foi explorado.

Há também no Brasil um potencial para ampliar a geração hidroelétrica através da melhor gestão do fluxo de água, repotenciação das usinas já existentes, e melhoramento tecnológico das turbinas. Segundo Berman (BERMAN, 2004) o país tem um potencial de repotenciação de mais de $34 \mathrm{mil} \mathrm{MW}$ em hidrelétricas, proveniente de usinas com mais de 20 anos e com capacidade acima de $30 \mathrm{MW}$. Segundo o MME o maior potencial hidroelétrico nacional está concentrado na Amazônia (BEN, 2005).

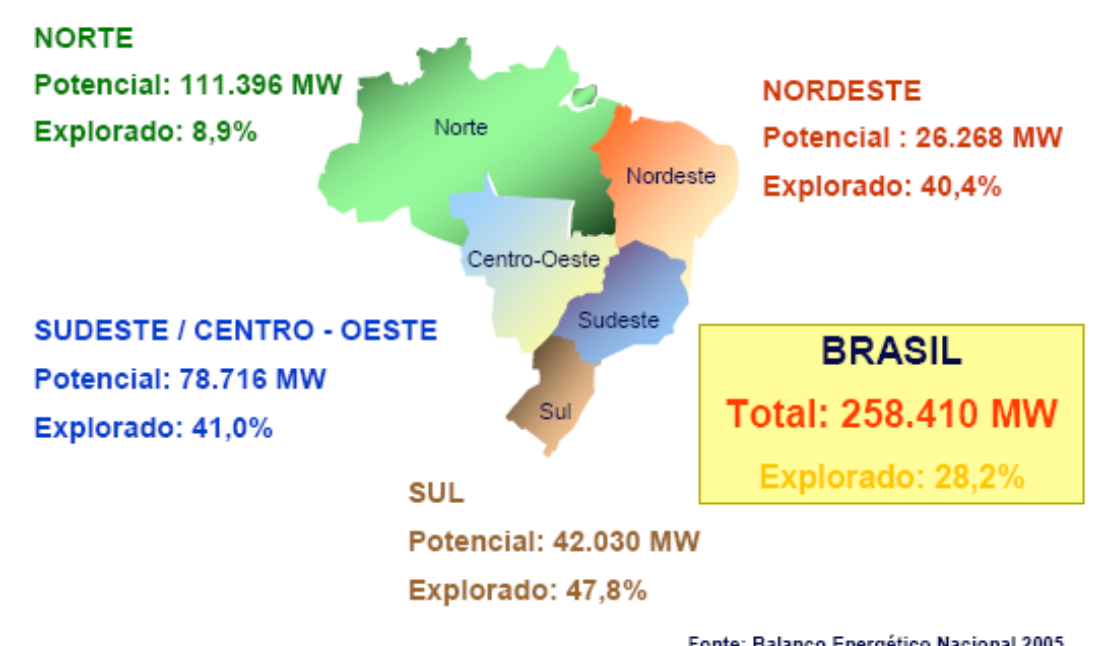

Fonte: (BEN, 2005)

Figura 2.5.1 - Potencial Hidroelétrico Explorado e Potencial por Região 
Segundo o Prof. Nival de José de Castro do GESEL - Instituto de economia da UFRJ, o potencial de bioeletricidade até 2020 será de 14 mil MW, ou seja, quase o triplo da produção atual (5.400 MW instalados) (ÚNICA, 2010). Esta energia é gerada no período de seca (abril a novembro) e portanto apresenta complementaridade com a hidroeletricidade. O potencial eólico é estimado em 143 mil MW no Atlas do Potencial Eólico Brasileiro (AMARANTE; BROWER; ZACK, 2001). Em 2010, temos 794MW instalados de energia eólica. (ANEEL, 2010)

O Brasil se destaca, mundialmente, pelo porte do sistema hídrico-térmico. A oferta de eletricidade no Brasil está concentrada nas empresas estatais (67\%), e a maioria sob gestão federal (23\%). Entretanto, a demanda está prioritariamente sob controle de agentes privados (88\%). No Norte, o parque gerador é exclusivamente hidrelétrico; no Nordeste, o parque gerador conta com geração hidroelétrica, termelétrica e recentemente iniciou a geração eólica. No Sudeste e Centro-Oeste, estão presentes a geração hidrelétrica, térmica (nuclear e fóssil), e a biomassa. No Sul, localizam principalmente as centrais alimentadas com carvão mineral.

O setor elétrico brasileiro está configurado em quatro submercados (Norte, Nordeste, Sudeste/Centro Oeste, e Sul) interconectados por grandes linhas de transmissão. O setor industrial e residencial são os maiores consumidores de energia elétrica no país e $60 \%$ do consumo nacional estão concentrados na região Sudeste e Centro-Oeste.

O Sistema Interligado Nacional - SIN é formado pelas empresas das regiões Sul, Sudeste, Centro-Oeste, Nordeste e parte da região Norte, abrangendo $96,6 \%$ da capacidade de produção de eletricidade do país. Os 3,4\% fora do SIN consistem de pequenos e isolados sistemas, principalmente na região amazônica (ONS, 2009). A rede básica de transmissão, compreendendo as tensões de $230 \mathrm{kV}$ a $750 \mathrm{kV}$, atingiu em dezembro de 2009 uma extensão de 95.465 km (ONS, 2009). A figura 2.5.2 apresenta de forma esquemática do sistema de transmissão brasileiro.

O sistema de distribuição, para atendimento ao mercado consumidor, abrange 64 concessionárias, estatais ou privadas, que atuam em todo o País. São atendidas cerca de 47 milhões de unidades consumidoras, das quais $85 \%$ são consumidores residenciais, em mais de $99 \%$ dos municípios brasileiros (ONS, 2009).

A titularidade das concessionárias abrange diversos agentes. Os governos federal, estaduais e municipais controlam as concessionárias estatais. Nas 
concessionárias privadas, os controladores incluem empresas nacionais, norteamericanas, espanholas e portuguesas.

Sistema de Transmissão 2009 - 2012

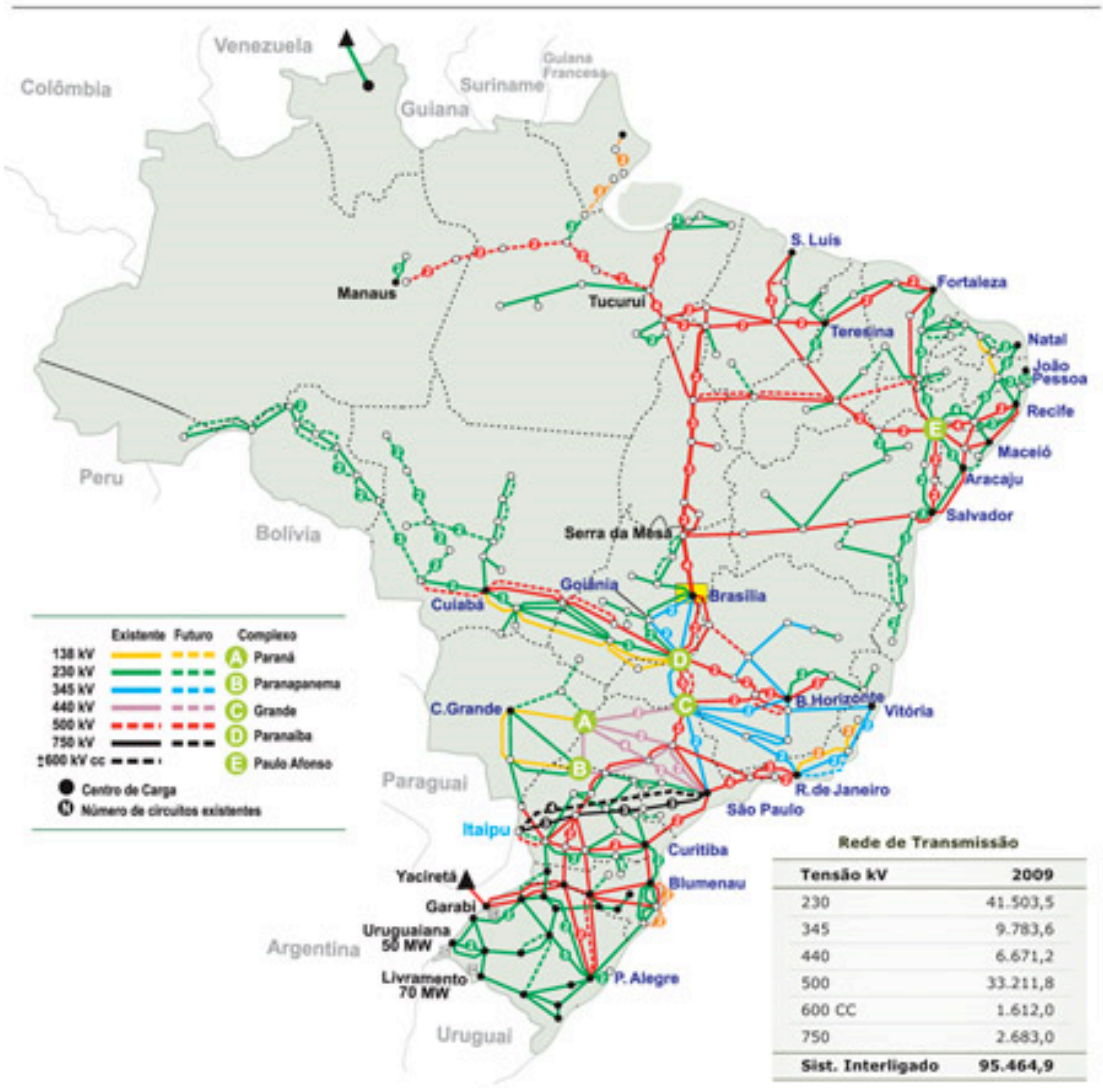

Fonte: Operador Nacional do Sistema (ONS 2009) Figura 2.5.2 - Sistema de Transmissão Brasil 


\section{CAPÍTULO 3 - MODELO INSTITUCIONAL DO SETOR ELÉTRICO E A POLITICA TARIFÁRIA}

\subsection{INTRODUCC̃̃O}

Este capítulo apresenta o histórico das políticas tarifárias do setor elétrico brasileiro, os modelos institucionais mais recentes e o impacto das atuais políticas tarifárias de energia elétrica na viabilidade de uma comercializadora de novas fontes de energias renováveis.

\subsection{AçõEs POLÍTICO-ECONÔMICAS E TARIFAS NO SETOR ELÉTRICO BRASILEIRO}

Até meados de 1950 o investimento privado manteve o setor elétrico brasileiro. Os reflexos da política que resultou no Código de Águas, em 1934, geraram a definição de tarifas de serviço público e decorrente inviabilidade de investimentos novos.

O efeito sobre o abastecimento se tornou agudo, de 1952 a 1967 (PIRES, 2001) e criou as bases para a estatização do setor elétrico, na base de $95 \%$, ao final da Década de 60.

Medidas para proteção econômica e antiinflacionárias, durante a crise mundial dos anos 80 , resultaram no congelamento de tarifas de energia elétrica e comprometimento empresarial das concessionárias. Houve, também, transferência de recursos das empresas mais eficientes para empresas menos capacitadas. Ao final dos anos 90 o setor elétrico brasileiro - praticamente falido - era caracterizado por empresas com dívidas, próximas de US $\$ 27$ bilhões. Havia 22 obras de usinas de geração paralisadas ou atrasadas. Foram canceladas 29 concessões que praticamente não tiveram as obras iniciadas (ABJAODE, 2007) 


\subsection{MODELOS INSTITUCIONAIS RECENTES}

A lei 8631 de 1993 viabilizou investimentos de recursos públicos para o saneamento econômico das empresas. Iniciou-se também um processo de recuperação tarifária, retirando-se as garantias de rentabilidade para investimentos realizados independentemente do caráter estatal ou privados dos recursos (ALMEIDA PRADO, 2008) ${ }^{1}$. A legislação criou também os princípios para que em 1996 fosse contratada pelo Ministério de Minas e Energia uma consultoria ${ }^{2}$ que criasse as bases de um moderno setor elétrico brasileiro. $O$ projeto desenvolvido tinha como princípios básicos:

- Realismo tarifário.

- Privatização.

- Competição nos segmentos de geração e comercialização.

- Operação regulada dos segmentos de distribuição e transmissão.

- Criação de três novos agentes institucionais: Agência Reguladora Independente (que posteriormente veio a se constituir na ANEEL); Operador Nacional Independente (que veio a se constituir no ONS); Câmara de Liquidação das Operações Comerciais, inicialmente o MAE - Mercado Atacadista de Energia e posteriormente a CCEE Câmara de Comercialização de Energia Elétrica.

Almeida Prado (ALMEIDA PRADO,2008) sustenta que entre as mudanças propostas, certamente a criação de um ambiente competitivo precisa ser elencada como das mais importantes. A possibilidade da competição surgiu legalmente com o advento da lei 9.074/95 de 7 de julho de 1995, que criou a figura do consumidor livre, que pode exercer o direito de escolha de seu fornecedor de energia elétrica.

Os consumidores potencialmente livres foram definidos como aqueles que possuem uma demanda contratada superior a $10 \mathrm{MW}$ e tensão de atendimento de $69 \mathrm{kV}$ ou superior. Depois de três anos, estes limites de demanda foram reduzidos para 3 MW e, desde 2003, a ANEEL tem o poder legal de efetuar novas reduções embora ainda não tenha optado por fazê-lo.

\footnotetext{
${ }^{1}$ Dados e informações colhidos em entrevista com Fernando Almeida Prado (2008).

${ }^{2} \mathrm{O}$ projeto foi coordenado pela consultoria inglesa Coopers \& Lybrand e foi conhecido como projeto RESEB - Reestruturação do Setor Elétrico Brasileiro.
} 
Consumidores ligados depois de 7 de julho de 1995 possuem apenas a restrição de demanda não sendo exigido nenhum limite legal relacionado com a tensão de atendimento. Para Almeida Prado, a citada lei assegura aos fornecedores e clientes de energia elétrica o livre acesso aos sistemas de distribuição e transmissão, mediante contratação dos serviços de transporte junto à concessionária de distribuição local, com o pagamento das tarifas de uso do sistema de transmissão e de distribuição, respectivamente TUST e TUSD.

A partir de 2008, as condições de elegibilidade foram flexibilizadas para consumidores com demanda contratada maior que $500 \mathrm{~kW}$, desde que a aquisição da energia fosse feita a partir de fontes incentivadas (Pequenas Centrais Hidroelétricas, Pequenas Centrais Térmicas que utilizem biomassa como combustível ou ainda Centrais Eólicas). Como estas fontes são mais onerosas, a ANEEL, o poder concedente, define um incentivo correspondente a $50 \%$ dos valores referentes às tarifas de uso do sistema elétrico (TUST/TUSD), incentivo este repassado às tarifas dos consumidores cativos.

A criação deste mercado de livre comercialização de energia elétrica provocou a necessidade da atuação de uma entidade para controle e liquidação das operações, inicialmente o Mercado Atacadista de Energia (MAE) que foi substituído pela CCEE - Câmara de Comercialização de Energia Elétrica.

Outro ponto de relevância, destacado por Almeida Prado, refere-se ao projeto concebido pela Coopers \& Lybrand e dedicado ao processo de privatização. Esta iniciativa foi realizada no Brasil, muito menos por razões ideológicas em busca de um Estado menor e de maior eficiência e sim pela real incapacidade do País de fazer frente aos investimentos em ampliação da capacidade instalada em geração e transmissão.

Segundo Almeida Prado, o processo de privatização foi iniciado em 1995 e priorizou o segmento das empresas distribuidoras com o intuito de que estas pudessem vir a se tornar as âncoras de um futuro processo de privatização das geradoras.

O autor destaca que cerca de $70 \%$ do mercado distribuidor nacional encontrase sob o controle de capital privado restando poucas empresas de expressão ainda sob controle estatal. Permanecem sob controle estatal a COPEL-PR, CEMIG-MG, CELESC-SC, CEEE-RS. Nas regiões Norte e Nordeste existem outras empresas de menor expressão sob controle estatal, a maioria em regime de intervenção por parte 
da Eletrobrás, decorrente de dificuldades financeiras vivenciadas nas empresas, como por exemplo, a CEPISA-PI e a CERON-RO.

No segmento da geração o processo ficou incompleto, pois a crise de abastecimento de 2001 e dificuldades políticas impediram a conclusão das privatizações deste segmento. Registram-se como processos importantes de privatização da geração, duas empresas paulistas, AES Tietê e Duke Energy, resultantes do processo de cisão acionária da CESP-SP e o processo de privatização do segmento de geração da Eletrosul, cujo controle foi adquirido pelo grupo Suez que no Brasil recebeu a designação de Tractebel Energia.

Almeida Prado destaca que o racionamento de 2001 provocou pesados prejuízos à economia brasileira. Os elevados reajustes tarifários criaram as condições políticas para que com a eleição de um governo de oposição ao presidente Fernando Henrique Cardoso (período 1995-2002), o modelo institucional do setor elétrico fosse amplamente revisado, com a criação de um novo marco legal do setor elétrico.

O Ministério de Minas e Energia então comandado pela Ministra Dilma Roussef diagnosticava, em 2003, que o modelo de competição projetado pela Coopers \& Lybrand falhara, pois o País tinha atravessado um longo racionamento, as tarifas públicas tinham se elevado mais que a inflação e novos investimentos em geração permaneciam tímidos. No entanto, a configuração de um novo marco institucional e regulatório demandou cerca de dois anos nos processos legislativos e de regulamentação, prazo no qual os investimentos em ampliação da capacidade instalada foram diminuídos em função da espera da regulamentação do novo ambiente. O modelo desenvolvido sob a coordenação da Ministra Dilma contemplava como premissas de sua concepção os seguintes aspectos:

- Reestruturação das funções de planejamento setorial.

- Criação de mecanismos de supervisão das condições de oferta de curto prazo.

- Contratação de Energia em prazos compatíveis com a amortização de investimentos de novas unidades geradoras.

- Definição das concessões baseadas na competição pelo menor preço de energia a ser oferecido pelos licitantes com garantia de compra pelas distribuidoras. 
- Existência simultânea de dois segmentos de comercialização: o ambiente regulado (ACR) e o ambiente desregulamentado (ACL).

- Compra de energia pelas distribuidoras na totalidade de seus mercados de forma consolidada em um pool, permitindo-se preços médios idênticos para todas as concessionárias de distribuição.

- Proibição de atividades comerciais das empresas distribuidoras em funções diferentes das definidas na concessão.

- Previsão de uma reserva de capacidade nos processos de definição de mercados a contratar visando aumentar a segurança no fornecimento.

- Restabelecimento do MME no papel de poder concedente.

\subsection{POLÍTICAS TARIFÁRIAS}

As políticas tarifárias de energia elétrica são fundamentais na análise da viabilidade de uma comercializadora de novas fontes de energias renováveis. É oportuno destacar que no período entre 1974 e 1993, vigorou no Brasil uma política de equalização tarifária cujo principal objetivo era propiciar o desenvolvimento de regiões mais pobres e facilitar a interiorização do País. Assim as tarifas eram idênticas para a mesma classe de consumidores independente do custo de produção das concessionárias.

Ainda mais, as empresas tinham restrições sobre a lucratividade permitida, sendo obrigadas a repassar para concessionárias menos eficientes as receitas superiores a um patamar estabelecido em lei. Por outro lado, uma remuneração mínima de $10 \%$ sobre os ativos em serviço também era definida em lei.

O Secretário Nacional de Energia no governo Fernando Henrique Cardoso, Peter Greiner, em sua análise da crise do racionamento de 2001 (GREINER, 2002), cita como fazendo parte dos antecedentes da crise o fato que as políticas tarifárias no período não eram indutoras de eficiência, fato ainda agravado pela inflação elevada que permeou a economia do Brasil no período, sempre acompanhada de intervenções do Ministério da Fazenda com congelamentos temporários das tarifas de energia elétrica ou definição de reajustes inferiores a desvalorização da moeda. Todos estes fatores teriam contribuído para a grave crise setorial que culminou com 
a inadimplência de mais de U\$27 bilhões, que foi saneada com a lei 8.631/93 com recursos do tesouro nacional.

Além do equacionamento financeiro do setor, a referida lei eliminou a equalização tarifária e os direitos de rentabilidade assegurados em lei por parte das concessionárias. No entanto uma nova política clara de definição de tarifas apenas viria a se consolidar com o advento da privatização e da consultoria da Coopers \& Lybrand.

Observa-se que as tarifas praticadas no mercado regulado tiveram suas bases definidas nos processos de privatização e são compostas de duas parcelas, a saber:

Parcela A - composta de preços considerados como não gerenciáveis, cujo repasse é automático para o consumidor. É composta de contratos de energia e encargos setoriais (como por exemplo, as tarifas de Itaipu ${ }^{3}$, os subsídios para os sistemas isolados na região amazônica e os impostos em geral).

Parcela B - composta de preços considerados como gerenciáveis pela ANEEL. Compõem a parcela B salários, depreciação, custos de capital, custos operacionais e de manutenção. São valores corrigidos anualmente pela variação do IGPM - FGV, índice de preços usualmente adotado pelo mercado de energia.

No Brasil, a formulação estabelecida nos contratos de concessão é definida segundo a fórmula:

$$
I R T=\left(V^{\prime} A_{1}+\text { VPBo }(I G P M-X)\right) / R A O
$$

Onde:

IRT - Índice de Reajuste Tarifário

$\mathrm{VPA}_{1}$ - Representa o valor da parcela de custos não controláveis para o ano um.

VPBo - Representa o valor da parcela de custos controláveis no ano zero.

IGPM - Índice Geral de Preços Mercado, indexador escolhido para o reajuste inflacionário de preços.

$\mathrm{X}$ - fator de produtividade.

RAo - Receita autorizada da concessionária no ano zero (que pelo menos em tese propiciava equilíbrio econômico financeiro à concessão na tríade mercado, tarifas e ativos ainda não depreciados no exercício).

\footnotetext{
${ }^{3}$ Usina binacional em associação como Paraguai cujos preços são cotados em dólar norteamericano.
} 
Almeida Prado salienta que dois aspectos chamam a atenção nesta formulação quando se analisam os riscos que impactam o consumidor em relação à definição de tarifas.

O primeiro trata de escolha, pelo regulador ${ }^{4}$, do indexador adequado para corrigir os custos gerenciáveis. A escolha do IGPM em detrimento de outros indexadores como o IPCA envolve conceitos econômicos que fogem aos objetivos deste trabalho.

A figura 3.4.1 apresenta a variação dos índices IGPM, IPC e IPCA no período de 2000 a 2010. Nota-se claramente o descolamento do IGPM em relação aos outros indicadores.

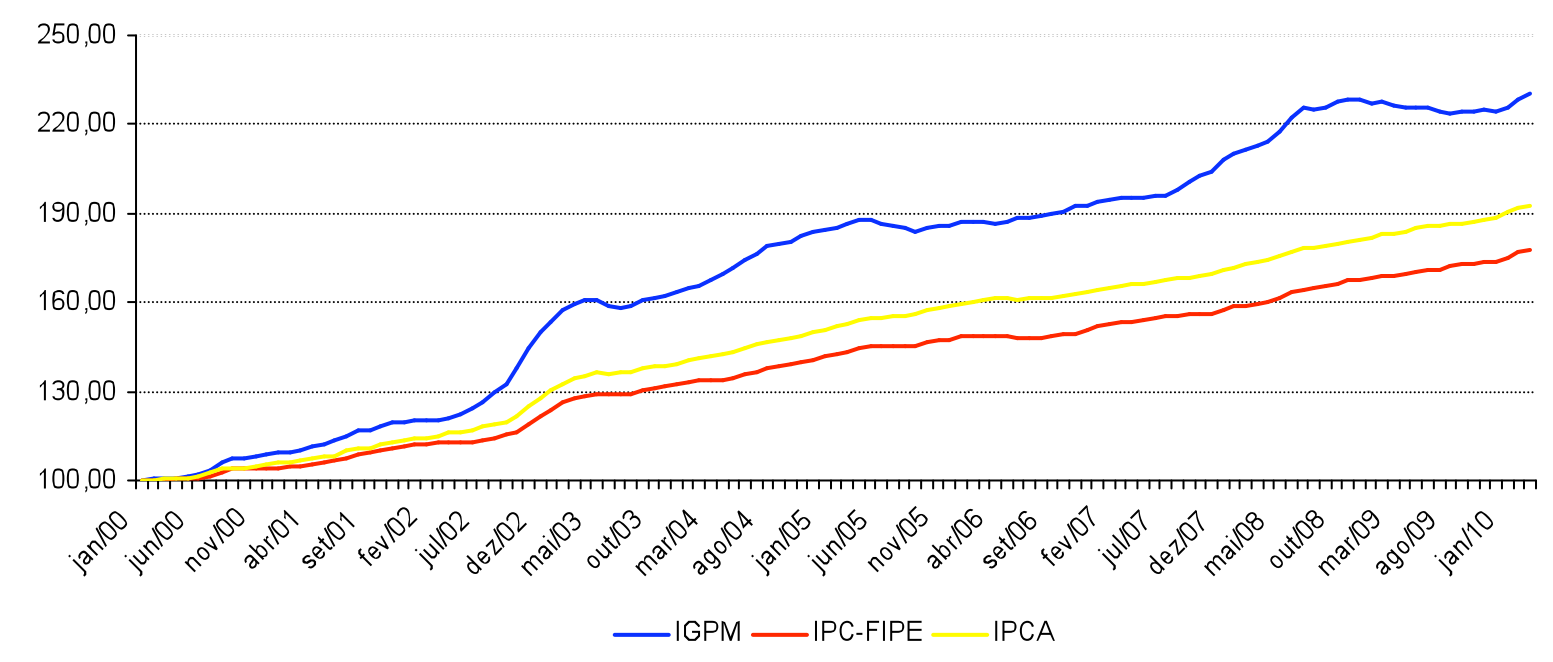

Fonte: (Banco Central do Brasil, 2010)

Figura 3.4.1 - Crescimento Percentual de Indicadores Econômicos

A Figura 3.4.2 apresenta um comparativo entre os indicadores econômicos com relação a tarifa média de energia, retirado dos estudos de Filho (FILHO D.K., 2009). No gráfico apresentado verifica-se o forte impacto na tarifa de energia elétrica pelas variações acumuladas do IGPM no período de 2001 a 2008 que resultou num aumento de $74 \%$.

\footnotetext{
${ }^{4} \mathrm{Na}$ verdade a escolha foi feita pelo BNDES que funcionava como definidor das políticas de privatização.
} 
Tarifas Médias do Industrial

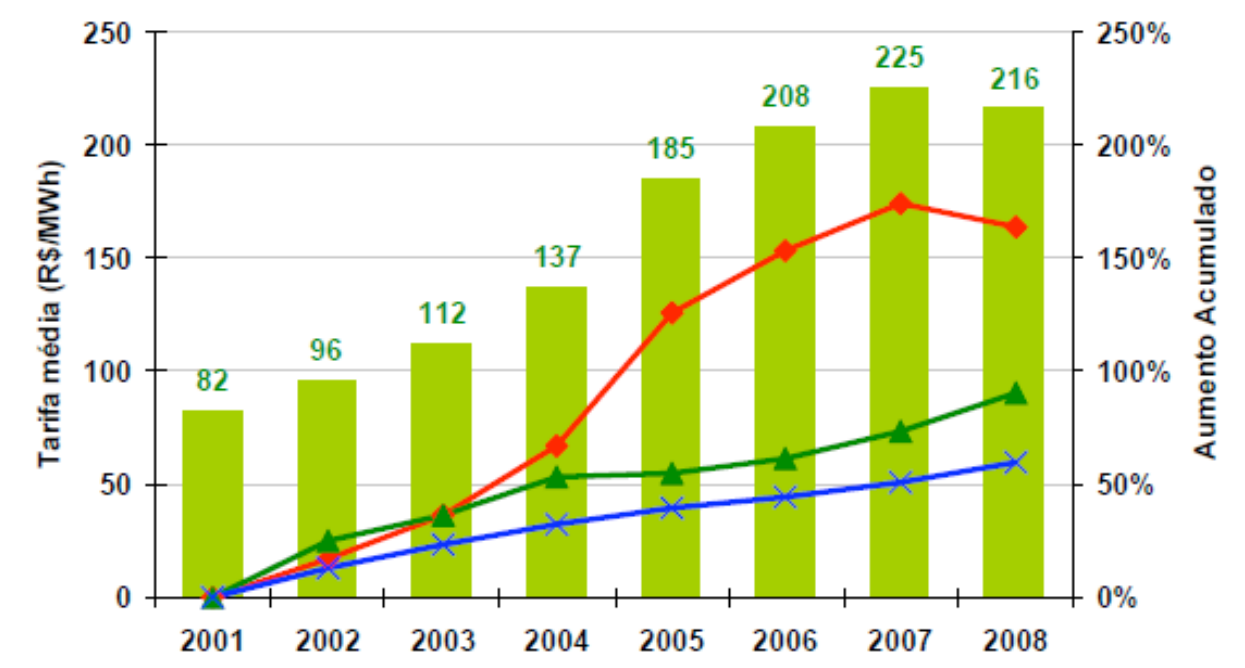

Industrial (R\$/MWh) $=$ Industrial (Aumento) $=$ IGP-M (Anual) IPCA (Anual)

Fonte: (FILHO D.K., 2009)

Figura 3.4.2 - Comparativo de Indicadores Econômicos IGPM e IPCA com Tarifa Industrial Média de Energia

Como é fácil perceber, analisando a Figura 3.4.1, o IGPM é de longe desde 2000 o índice com maior variação dos preços ali indexados com forte impacto nas tarifas conforme o modelo de privatização proposto. Por outro lado é forçoso reconhecer que o segmento de energia elétrica "per se" e acentuadamente em decorrência da privatização, foi mais fortemente afetado pela variação do dólar norteamericano, o que poderia justificar a escolha do IGPM como indexador preferencial do setor. Outro fato importante é de que a cada 4 ou 5 anos ${ }^{6}$ é feita uma revisão tarifária onde a $A N E E L$ estabelece uma reformulação geral do equilíbrio econômico tarifário das condições do contrato. Estas revisões são baseadas no desempenho de uma empresa de referência que atuasse na mesma área de concessão da empresa real com investimentos prudentes e gestão competente.

As revisões tanto podem indicar reajustes superiores à inflação como definir reduções tarifárias. Os anos de 2007 e 2008 representam para a maior parte das concessionárias de distribuição, período referente ao segundo ciclo de revisões. 0 primeiro processo foi de maneira geral representativo de reajustes superiores á inflação, já o segundo ciclo indicou uma redução tarifária.

\footnotetext{
${ }^{5}$ Tarifas de Itaipu, importação de equipamentos, financiamento da privatização, combustíveis de térmicas e conta de combustíveis - CCC.

${ }^{6}$ Depende do processo de privatização, as primeiras privatizações previam prazos mais longos entre revisões tarifárias.
} 
Esta situação aparentemente poderia ser contraditória em relação ao cenário de falta de condições de segurança de suprimento de energia elétrica no período 2010-2015, que deveria levar a reajustes superiores à inflação. No entanto a redução substancial das taxas de juro (SELIC), a redução da cotação do dólar americano, os ganhos de competitividade decorrentes de aprimoramentos de processos e gestão no período pós-privatização são fatores que contribuem de forma importante para esta redução de tarifas. Ainda importante nesta redução está o fato que com o encerramento de parte dos contratos de longo prazo entre geradores e distribuidores, a parcela dos contratos da chamada energia "velha", passa a ter maior participação percentual no portfólio de contratos.

Desde 2003, a ANEEL, visando à busca de um realismo tarifário, vem aplicando reajustes não lineares pelas diversas classes de tensão em uma tentativa de eliminar subsídios cruzados. Este procedimento fez com que os reajustes das classes de alta tensão tenham sido mais expressivos desde então, principalmente para os consumidores conectados em tensão igual ou superior a $88 \mathrm{kV}$.

Áreas de concessão com maior extensão rural devem ser mais afetadas em futuros reajustes em decorrência dos programas de universalização do atendimento $^{8}$. O mesmo se aplica para as concessionárias que possuem elevada participação de redes particulares, que, por força da lei 10.848, devem ser incorporadas ao patrimônio das empresas de distribuição com as decorrentes necessidades de manutenção e operação. Pode-se citar a CPFL, Elektro e Enersul como concessionárias afetadas por esta obrigação.

Por outro lado concessionárias localizadas em áreas urbanas possuem a vantagem de terem seus custos marginais de expansão decrescentes, pelo adensamento natural de investimentos em redes já existentes. Possuem, no entanto a desvantagem de terem custos associados a problemas típicos das grandes metrópoles como trânsito caótico e inundações, o que complica em muito o desempenho de manutenção e os indicadores de qualidade como aqueles referentes a interrupções. Estas regiões possuem ainda problemas com a grande

\footnotetext{
${ }^{7}$ Energia proveniente de usinas consideradas depreciadas e que teve leilão com preços muito reduzidos em dezembro de 2005, com distorção promovida pelo novo modelo regulatório elaborado pelo Ministério de Minas e Energia.

${ }^{8}$ Estes programas exigem altos investimentos para atender cargas não tão significativas, com pequena ou nenhuma lucratividade.
} 
incidência de ligações clandestinas, cujos reflexos inevitavelmente em parte são repassados às tarifas dos clientes regulados.

Sabe-se que nos últimos anos, a competição acirrada tem levado à procura constante de redução de custos nos mais diversos segmentos da economia. No entanto, os consumidores cativos de energia elétrica estão submetidos a pressões de custos, contra as quais não existem alternativas. As regras básicas destes reajustes já foram citadas anteriormente, no entanto algumas das pressões altistas das tarifas independem das regras e sim da ação governamental.

Os encargos que compõem as tarifas de energia elétrica no Brasil representam um dos mais importantes fatores geradores de pressões para elevação das tarifas.

O Reajuste Tarifário Extraordinário (RTE) é um bom exemplo de distorção de mercado por ação de novos encargos. O racionamento de 2001 provocou pesadas perdas às concessionárias de distribuição. Não bastasse a restrição à comercialização de $20 \%$ em média de seu mercado em função da escassez de oferta de eletricidade, as distribuidoras não puderam reduzir suas despesas, pois as operações de base permaneceram as mesmas enquanto que aquelas vinculadas ao atendimento comercial foram muito complicadas.

O mesmo se pode dizer das áreas regulatórias e de suporte de informática, comunicação e faturamento que diariamente necessitavam se adequar aos regulamentos publicados pela Câmara de Gestão da Crise. No entanto, a maior influência na saúde financeira das distribuidoras foi provocada pela ruptura do comportamento de mercado.

Os consumidores finais, ao se virem obrigados a reduzir seu consumo, descobriram boas práticas de eficiência energética e outras tantas providências que levaram ao combate do desperdício de eletricidade. Muitas empresas também adquiriram geradores e passaram a utilizar estes equipamentos nos horários de ponta, onde as tarifas são mais elevadas.

Esses procedimentos, ao permanecerem em uso após o término do racionamento, levaram a uma alteração no mercado das distribuidoras, que, em muitos casos, representou uma retroação de até 4 anos nos montantes comercializados. Almeida Prado ressalta que o mercado de baixa tensão, em 
especial na classe residencial ${ }^{9}$ foi dos mais afetados. As Figuras 3.4 .3 e 3.4 .4 evidenciam esta situação através da análise do consumo de energia nas regiões Sudeste e Sul respectivamente.

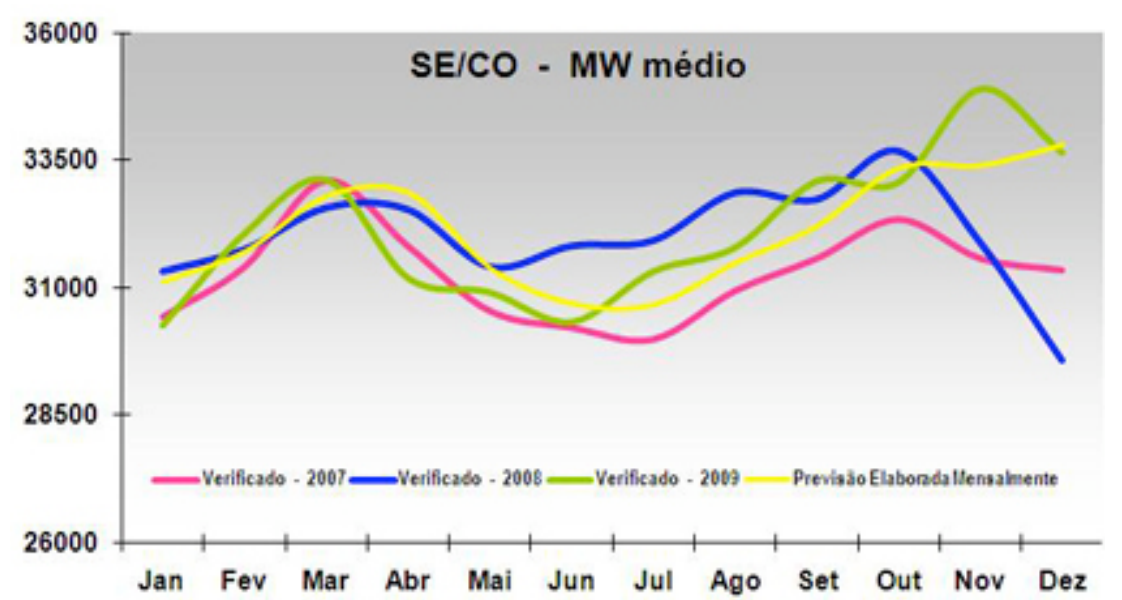

Fonte: (ONS, 2009)

Figura 3.4.3 - Consumo de Energia na Região Sudeste/Centro Oeste no Período 2007/2008/2009

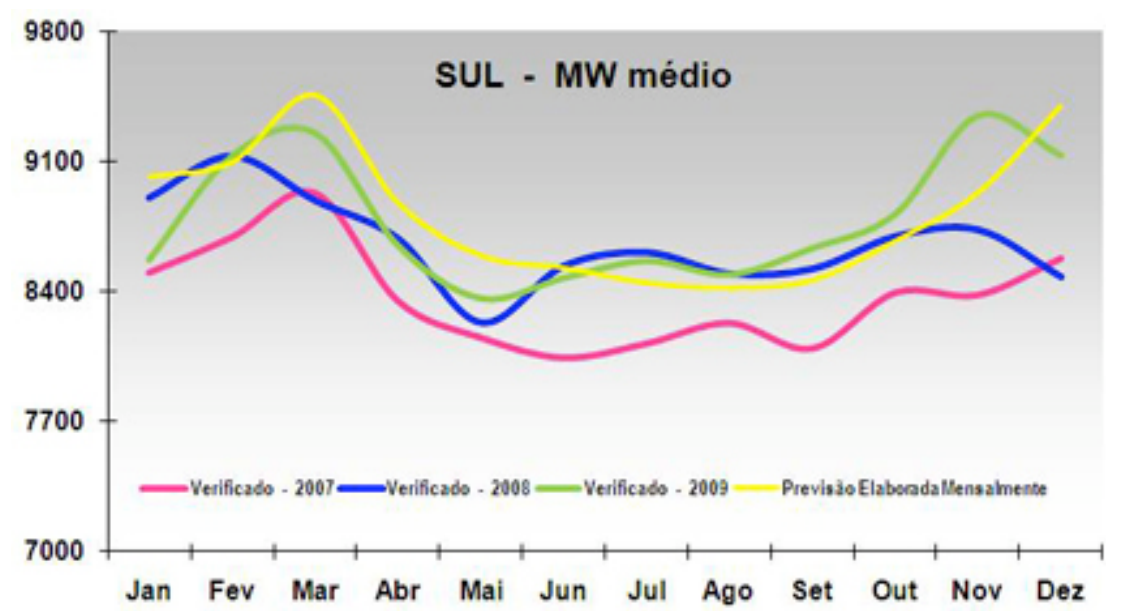

Fonte: (ONS, 2009)

Figura 3.4.4 - Consumo de Energia Elétrica na Região Sul no Período 2007/2008/2009

Em decorrência dessa situação, redução de mercado e não redução simultânea de despesas, as empresas distribuidoras enfrentaram uma difícil situação financeira. Ocorre que a maior parte das geradoras, no momento do racionamento, era controlada pelo governo federal e por alguns Estados. O cumprimento puro e simples dos contratos de suprimento com suas pesadas penalidades colocaria não mais as distribuidoras em situação financeiramente difícil, mas sim as geradoras. $O$ governo procurou uma solução negociada, evitando-se os prejuízos que teria que

\footnotetext{
${ }^{9} \mathrm{~A}$ classe residencial é aquela de maior margem de rentabilidade.
} 
arcar com suas empresas geradoras e eliminar o risco jurídico que poderia arrastarse por anos.

A solução encontrada foi um acordo comercial, onde as partes se comprometiam a não acionar a justiça, renunciando expressamente a qualquer litígio. Pelo governo foi negociado um empréstimo pelo BNDES que resolveria o problema de caixa das distribuidoras. Para fazer frente ao pagamento desse empréstimo a ANEEL autorizou um reajuste extraordinário de tarifas RTE no valor de $7,9 \%$ para todos os consumidores exceto os residenciais, rurais e lluminação pública $^{10}$ que tiveram um reajuste de $2,9 \%$.

O reajuste iria perdurar por prazos diferentes na proporção dos prejuízos sofridos pelas distribuidoras, sendo que o prazo médio foi de 5 anos, embora existam casos como o da CEMIG onde o RTE continua a vigorar (ANEEL, 2010).

Obviamente este reajuste causou grande polêmica, uma vez que a gestão da crise de abastecimento de energia elétrica provocada pelo racionamento empurrou para os consumidores a responsabilidade pelo restabelecimento do equilíbrio econômico financeiro das empresas elétricas.

A tarifação no setor energético foi usada, adicionalmente, como instrumento de arrecadação de tributo, uma vez que o governo Brasileiro descobriu que o setor elétrico tem a eficácia que falta às Secretarias de Receita: a cobrança do encargo ou tributo é feita juntamente com a conta de energia, por ser um bem essencial, cujo fornecimento pode ser interrompido em caso de inadimplência.

As tarifas elétricas exibem outra face desconhecida, uma vez que embute os custos governamentais determinados pela carga tributária, fato esse freqüentemente criticado por diversos segmentos da sociedade da mesma maneira que acontece com os encargos setoriais.

Os seguintes tributos e encargos setoriais que incidem, direta, ou indiretamente, sobre as tarifas de energia elétrica são: a Reserva Global de Reversão - RGR, a Conta de Consumo de Combustíveis - CCC, a Conta de Desenvolvimento Energético - CDE, a Taxa de Fiscalização da ANEEL, a compensação financeira pelo uso de recursos hídricos, o Uso de Bem Público UBP, o Encargo de Capacidade Emergencial - ECE ${ }^{11}$, o Encargo de Serviços do Sistema - ESS, o investimento compulsório em Pesquisa e Desenvolvimento e em

\footnotetext{
${ }^{10}$ Os consumidores classificados como baixa renda foram excluídos desse reajuste.

${ }^{11}$ Esta cobrança foi extinta em dezembro de 2005.
} 
Eficiência Energética (P\&D), o custeio do ONS e da CCEE, as contribuições sociais para o Programa de Integração Social - PIS e para o Programa de Formação do Patrimônio do Servidor Público - PASEP, a Contribuição Social para o Financiamento da Seguridade Social - Cofins, a Contribuição Social sobre Lucro Líquido - CSLL, e o Imposto de Renda.

Além disso, há também a incidência de tributos diretos ao consumidor, que são arrecadados pelas concessionárias e repassados aos Estados e Municípios, tais como o Imposto sobre a Circulação de Mercadorias e Serviços - ICMS e a Contribuição para lluminação Pública - CIP.

Em estudo realizado pelo Instituto Acende Brasil e a consultoria Price, Waterhouse \& Coopers (Acende, 2007) fica clara a evolução destes tributos e encargos que, já em 2006, ultrapassou a barreira de $\mathrm{R} \$ 39$ bilhões. A Tabela 3.4.1 apresenta esta evolução.

Tabela 3.4.1 - Encargos e Tributos Aplicados ao Setor Elétrico

\begin{tabular}{|c|c|c|c|c|c|c|}
\hline \multicolumn{4}{|c|}{$\begin{array}{l}\text { Carga Consolidada de Tributos e Encargos } \\
\text { Consolidação }\end{array}$} & \multicolumn{3}{|c|}{ PRICEWATERHOUSECOPERS 圈 acende Brasil } \\
\hline & 1999 & 2002 & 2003 & 2004 & 2005 & 2006 \\
\hline \multicolumn{7}{|c|}{ Arrecadação [\% da Receita Bruta] } \\
\hline Federais & $7,90 \%$ & $6,90 \%$ & $9,08 \%$ & $10,17 \%$ & $12,67 \%$ & $13,29 \%$ \\
\hline Estaduais & $21,35 \%$ & $17,51 \%$ & $20,57 \%$ & $20,69 \%$ & $19,67 \%$ & $21,00 \%$ \\
\hline Municipais & $0,02 \%$ & $0,05 \%$ & $0,18 \%$ & $0,04 \%$ & $0,09 \%$ & $0,06 \%$ \\
\hline Trabalhistas & $4,79 \%$ & $2,67 \%$ & $2,33 \%$ & $2,17 \%$ & $1,90 \%$ & $1,85 \%$ \\
\hline Setoriais & $6,17 \%$ & $8,79 \%$ & $10,08 \%$ & $11,69 \%$ & $9,38 \%$ & $10,12 \%$ \\
\hline TOTAL & $40,23 \%$ & $35,91 \%$ & $42,24 \%$ & $44,76 \%$ & $43,70 \%$ & $46,33 \%$ \\
\hline \multicolumn{5}{|c|}{ Receita Bruta da Amostra [R\$ bilhões] } & \multicolumn{2}{|c|}{$+6,0 \%$} \\
\hline & 32,3 & 59,7 & 63,9 & 75,6 & 80,6 & 84,9 \\
\hline \multicolumn{5}{|c|}{ Tributos e Encargos [R\$ bilhões] } & \multicolumn{2}{|c|}{$+5,6 \% \uparrow$} \\
\hline & 13,0 & 21,4 & 26,9 & 33,8 & 35,2 & 39,3 \\
\hline & & & & & \multicolumn{2}{|c|}{$+11,6 \% \uparrow$} \\
\hline
\end{tabular}

Fonte: (ACENDE BRASIL; PW\&C, 2007)

No mesmo estudo os tributos e encargos são detalhados demonstrando seu grande impacto na atividade de distribuição de energia elétrica atingindo mais de $45 \%$ da receita bruta. A Figura 3.4.5 (Acende Brasil, PW\&C, 2007) detalha estes dispêndios. 
Carga Consolidada de Tributos e Encargos Consolidação

PRICENATERHOUSECOPERS 园 acende Brasil

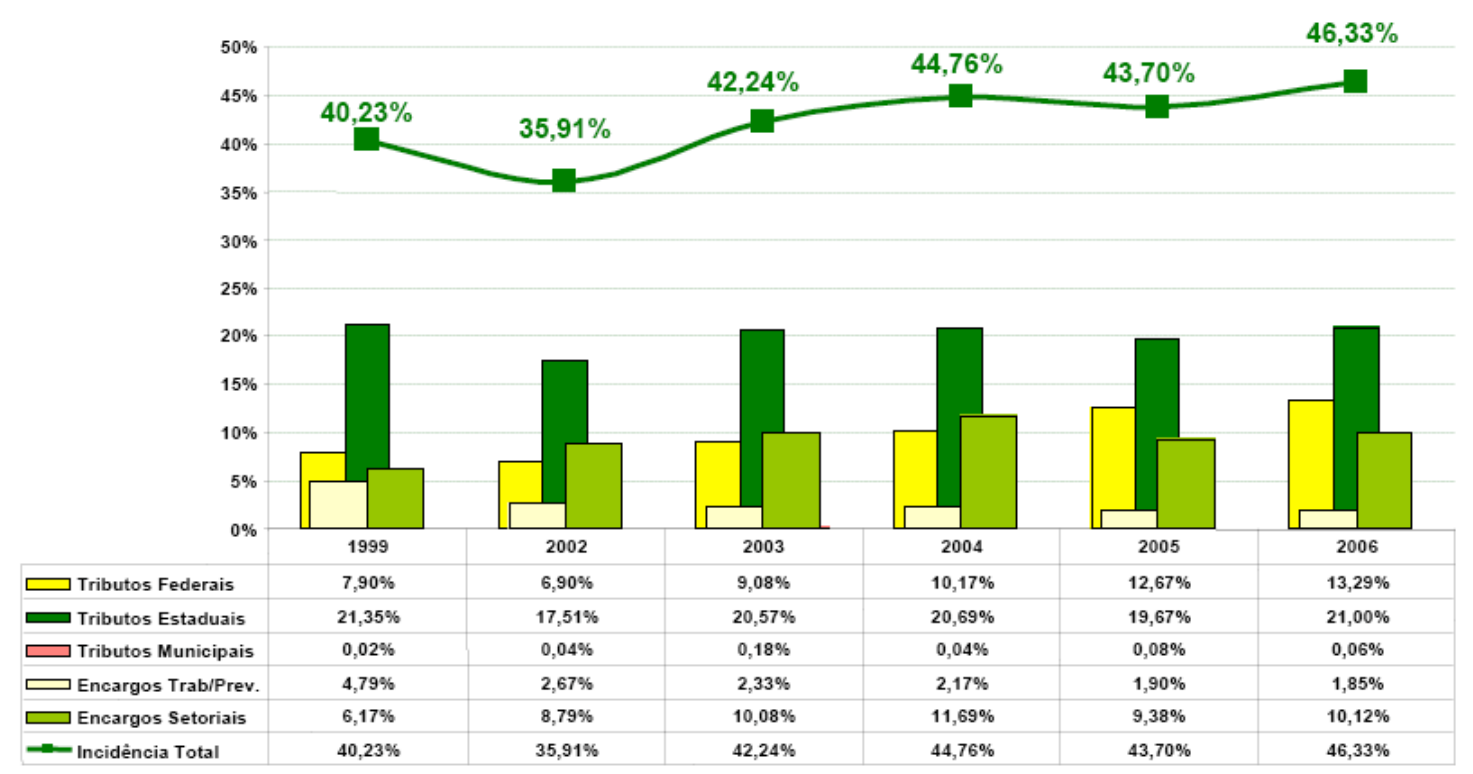

Figura 3.4.5 - Carga Consolidada de Tributos e Encargos

Fonte: (ACENDE BRASIL; PW\&C, 2007)

Cabe destacar que entidades aparentemente com interesses conflitantes, ABRADEE e ABRACE, se posicionam da mesma forma contra o excesso de custos induzidos nas tarifas finais aos consumidores. De um lado a preocupação diz respeito à imagem das distribuidoras e um acréscimo do risco de inadimplência dos consumidores de energia elétrica. De outra parte, existe insatisfação com a perda de competitividade do setor produtivo.

Apesar das queixas do setor, os valores arrecadados correspondem, de maneira aproximada, ao dobro da necessidade de investimentos nacionais em infraestrutura do setor elétrico, embora persistam os riscos de novo desabastecimento de energia elétrica ao final desta década.

O cenário aponta para a tendência de elevação dos custos e dos efeitos destes nas tarifas do setor industrial (Figura 3.4.6). É o que poderá acontecer, por exemplo, caso seja implementada a reforma tributária com a unificação de alíquotas do ICMS. 


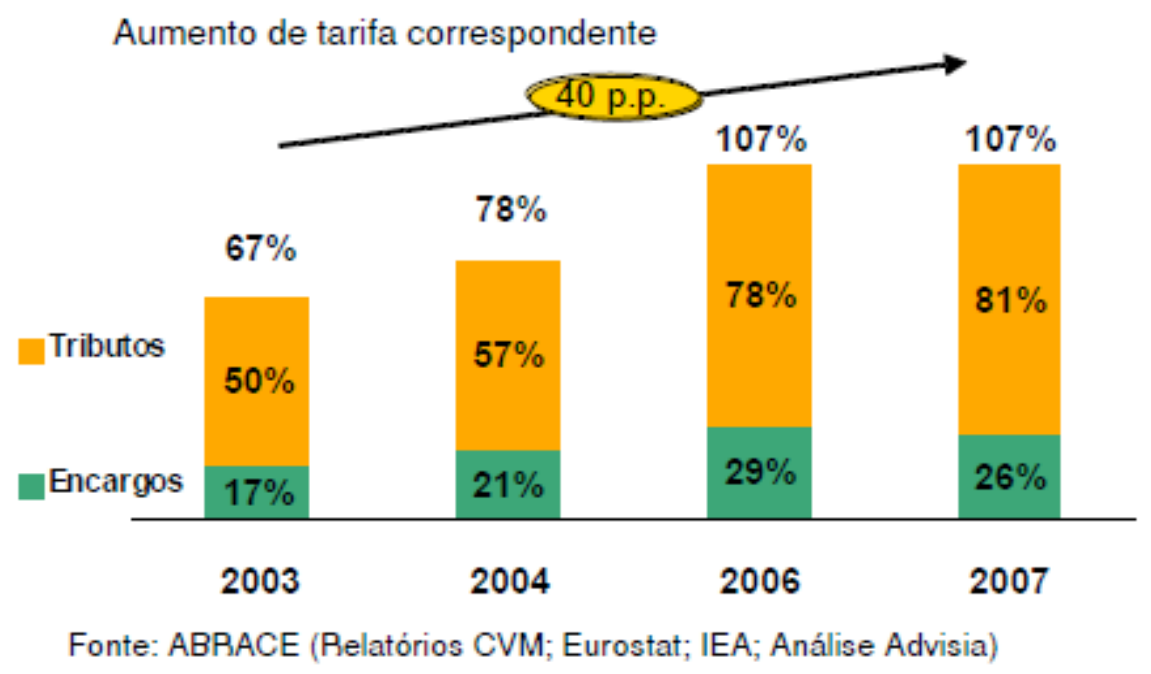

Figura 3.4.6 - Escalada da Tarifa Devido aos Encargos e Tributos

Fonte: (FILHO,D.K. 2009)

Filho (FILHO,D.K. 2009) sustenta que a carga tributária em outros países é em média $70 \%$ inferior à do Brasil (Tabela 3.4.2).

Carga tributária na tarifa final de energia elétrica em 2007

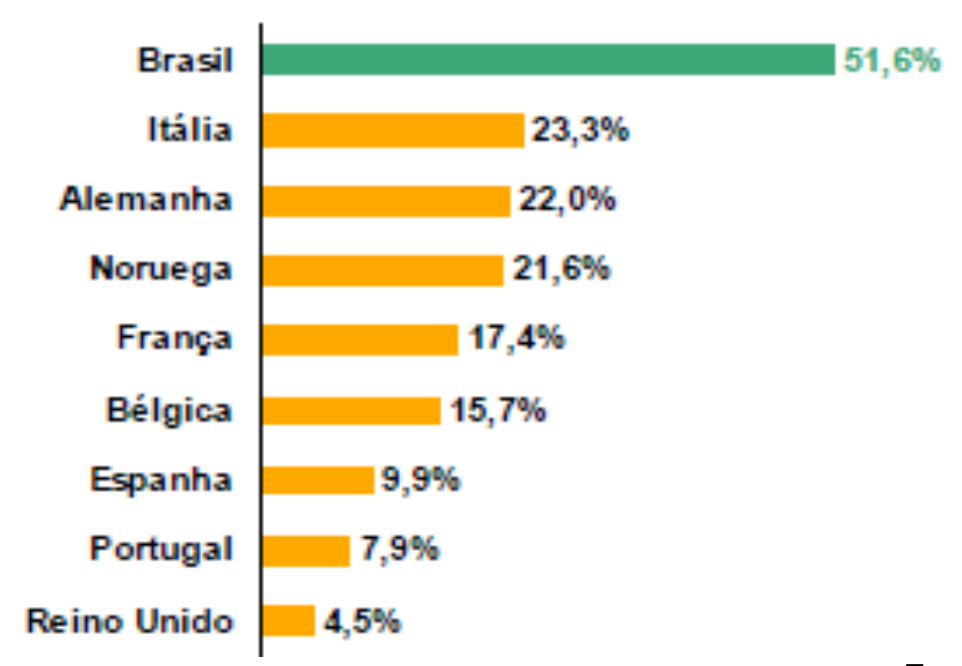

Fonte: (FILHO D.K., 2009)

Figura 3.4.7 - Estudos Comparativos da Carga Tributária no Setor Elétrico

O impacto substantivo do preço das tarifas é notório, pois, afeta a geração de renda, inflação e desemprego (Tabela 3.4.3), segundo estudos realizados pela FGV (GARCIA; SOUZA; CÂMARA, 2003). 


\begin{tabular}{|c|c|c|c|}
\hline $\begin{array}{l}\text { Energia } \\
\text { Elétrica }\end{array}$ & $\begin{array}{c}\text { PIB } \\
\text { pontos } \\
\text { percentuais }\end{array}$ & $\begin{array}{c}\text { Inflaçāo } \\
\text { pontos } \\
\text { percentuais }\end{array}$ & $\begin{array}{c}\text { Emprego } \\
\text { pontos } \\
\text { percentuais }\end{array}$ \\
\hline ス $30 \%$ & ע 1,2 & ス 1,3 & ע 0,7 \\
\hline ע $30 \%$ & $\pi 1,2$ & ע 1,3 & 入 0,7 \\
\hline
\end{tabular}

Fonte: (GARCIA; SOUZA; CÂMARA, 2003)

A análise dos reajustes tarifários das principais concessionárias de distribuição de energia, no período de 1999-2007, foi realizada pela empresa Sinerconsult Consultoria Treinamento e Participações Ltda. Os resultados foram apresentados sob a forma de números-índice e comparados com indexadores de inflação calculados no mesmo período de tempo ${ }^{12}$

O tratamento dos números-índice para as concessionárias das regiões Sul, Sudeste e Centro Oeste do Brasil não esgota a análise feita, mas demonstra a evidente tendência das tarifas subirem de maneira superior aos valores da inflação. Este dado demonstra a real possibilidade de um mercado para comercialização de energia proveniente de fontes diferentes das empresas reguladas.

Se, de um lado, a política de aumento dos valores das tarifas é uma realidade, segundo a ação do governo, não há, de outro lado, linearidade nos reajustes para as concessionárias, segundo o realismo tarifário da ANEEL.

O estudo da Sinerconsult (2007) idealizou duas empresas hipotéticas: uma classificada na classe A2 (conexão de alta tensão atendida entre 88 e 138 kV), típica de um consumidor eletro-intensivo de médio para grande porte; outra A4 (conexão de média tensão atendida entre 2,3 e 25 kV). As seguintes características foram adotadas para caracterizar os consumidores hipotéticos:

\section{Consumidor A2}

Demanda Ponta $=6.000 \mathrm{~kW}$

Demanda Fora de Ponta $=10.000 \mathrm{~kW}$

Fator de Carga na Ponta $=0,85$

\footnotetext{
${ }^{12}$ Cada concessionária tem a definição de seus reajustes em um mês previamente definido, por exemplo, a AES Eletropaulo tem suas tarifas reajustadas a cada mês de julho. Portanto a comparação de índices de inflação para esta concessionária compreendem o período de julho de um ano até junho do ano subseqüente.
} 
Fator de Carga Fora de Ponta $=0,70$

\section{Consumidor A4}

Demanda Ponta $=1.000 \mathrm{~kW}$
Demanda Fora de Ponta $=1.000 \mathrm{~kW}$
Fator de Carga na Ponta $=0,70$
Fator de Carga Fora de Ponta $=0,70$

Os referenciais tarifários foram obtidos no endereço eletrônico da ANEEL, www.aneel.gov.br, com acesso em diversas datas no mês de dezembro de 2007. As informações dos indicadores econômicos foram obtidas no endereço eletrônico www.debit.com.br também em diversas datas no mês de dezembro de 2007.

Como cada concessionária possui uma data de reajuste e ou de revisão tarifária sempre no mesmo mês do ano civil, os indicadores econômicos foram apurados no mesmo referencial de 12 meses que acompanham os reajustes da ANEEL. Para efeito desta análise os cálculos foram feitos sem impostos.

As informações são apresentadas na forma de dois gráficos para cada concessionária estudada, o primeiro na forma de número índice comparada à evolução das tarifas aplicadas a o consumidor hipotético característico de uso eletrointensivo. O segundo apresentando o valor em $\mathrm{R} \$$ (mil) que comporia a conta sem impostos desse consumidor.

Segundo a Sinerconsult (2007), as curvas da evolução das tarifas e preços guardam uma semelhança homotética, indicando que de maneira geral e sistemática os reajustes das concessionárias foram superiores aos índices de métricas de inflação. Esta conclusão perdura para ambas as classes tarifárias (A2 e A4).

Apenas a título de exemplo, a diferença expressiva entre os preços praticados pela AES Sul e pela RGE decorre da estratégia de compra de energia destas empresas, que como se sabe são repassados integralmente aos consumidores.

Assim o sistema atua com um efeito perverso, na medida em que uma estratégia equivocada da concessionária se reflete nos custos do consumidor. Este efeito parece estar minimizado na medida em que, desde o novo marco regulatório a compra de energia em contratos de longo prazo somente pode ser feita através de leilões públicos organizados pelo Ministério de Minas e Energia e com repasse idêntico para cada uma das concessionárias.

Embora possa ser considerada uma evolução, a legislação prevê a manutenção de contratos anteriormente firmados entre agentes (respeito a 
contratos) que inclusive podiam ser feitos entre agentes de mesmo controle acionário. Assim o efeito de contratos de compra de energia somente poderá ser desconsiderado no longo prazo.

Algumas concessionárias terão pressão altista de custos com a necessidade de expansão do atendimento (universalização), sendo exemplos desta situação a CEMIG, ELEKTRO, ENERSUL e CEMAT. Outras terão o mesmo efeito pela necessidade de incorporação de redes particulares, sendo bons exemplos entre as empresas estudadas a ENERSUL, CEMAT e a CPFL Paulista.

De modo geral, não existe espaço para reajustes superiores à inflação pela criação de novos encargos, exceto no caso da reforma tributária onde a eventual padronização do ICMS (atualmente sem padronização em diversos estados pode ocorrer pela alíquota teto, como por exemplo, RJ e MT).

Desta forma a seleção da região de atuação de uma empresa comercializadora de energia elétrica de NFER deverá priorizar regiões onde o custo de energia seja relevante, ou seja, regiões onde as tarifas sejam mais caras.

Mesmo que pressões decorrentes de crise de abastecimento venham a se instalar, o custo relativo deverá partir da situação atual. Ressalte-se que com o advento da perda conjuntural de competitividade do mercado livre, as concessionárias de serviço público não terão interesse em minimizar custos em busca de manutenção de clientes em sua base de mercado.

$\mathrm{O}$ assunto tarifário foi abordado em grande profundidade pois sua influência tanto na elaboração do marco regulatório como na definição de uma tarifa para um eventual modelo feed-in é fundamental. A viabilidade de uma comercializadora passa pelo entendimento da estrutura tarifária, o marco regulatório ideal e um modelo de comercialização viável. 


\section{CAPÍTULO 4 - REVOLUÇÃO ENERGÉtICA PARA UMA NOVA MATRIZ ELÉTRICA}

\subsection{INTRODUCCÃO}

Este capítulo apresenta dois cenários distintos para uma matriz elétrica brasileira até 2050. O primeiro cenário é apenas uma extrapolação do modelo proposto pelo Ministério de Minas e Energia para o período de 2050. O cenário alternativo foi elaborado para identificar o mercado potencial que pode ser desenvolvido nos próximos 40 anos com as devidas políticas públicas e consequentemente o ambiente ideal para uma comercializadora de novas fontes de energias renováveis.

\subsection{REVOLUÇ̃̃o ENERGÉTICA}

Em 2006 visando propor uma matriz elétrica alternativa à sinalizada pelo governo, foi desenvolvido o cenário de [r]evolução energética. O estudo foi conduzido por M.Furtado e R. Baitelo (Greenpeace Brasil, 2007) em parceria com o GEPEA (Grupo de Energia do Departamento de Engenharia de Energia e Automação Elétricas da USP) e apresentou três cenários elétricos: um cenário de referência, um cenário intermediário e um cenário de [r]evolução energética. $O$ primeiro foi elaborado com dados da Empresa de Pesquisa Energética (EPE), órgão ligado ao ministério de Minas e Energia, que consta do estudo "Mercado de Energia elétrica 2006-2015". O Cenário Intermediário foi elaborado de acordo com as premissas do GEPEA. E o cenário de [r]evolução energética foi elaborado pela Greenpeace, considerando a ampla utilização de novas fontes de energias renováveis e eficiência energética e a redução de geração fóssil e nuclear. Os dados comparativos apresentados neste capítulo abordam apenas os cenários referência e [r]evolução energética apenas. 
Os princípios fundamentais que nortearam o estudo de [r]evolução energética foram os seguintes:

\subsubsection{A implantação de sistemas de energia limpa, soluções renováveis e descentralizadas}

As tecnologias existentes podem ser utilizadas de modo mais eficiente na produção de energia. Novas fontes de energias renováveis e medidas de eficiência energética estão disponíveis, são viáveis e cada vez mais competitivas. As energias eólica e solar vêm crescendo de forma considerável desde a década passada. A descentralização da produção de energia traz como benefícios a redução das perdas de transmissão de energia e o maior aproveitamento de recursos energéticos locais.

\subsubsection{Respeito aos limites naturais}

A sociedade deve aprender a utilizar recursos naturais de forma sustentável. A utilização de energias renováveis e o uso racional desta energia produzida incentivam estas práticas, na medida em que as reservas fósseis deixam de ser gradativamente utilizadas para a geração de energia e menos pressão é imposta sobre o ambiente.

\subsubsection{Eliminação gradual de energias poluentes}

As usinas a carvão e nucleares devem ser gradualmente eliminadas e substituídas. O uso de petróleo, carvão e diesel é extremamente proibitivo no atual momento em que emissões oferecem um perigo real à manutenção da vida no planeta. A energia nuclear tampouco é uma alternativa à redução de emissão de 
gases de efeito estufa, uma vez que considerando seu ciclo completo de vida e portanto incluindo a fase de mineração e preparação do combustível nuclear a mesma apresenta emissões equivalentes à usinas térmicas a gás natural. Além disso, as usinas nucleares apresentam enormes riscos ambientais.

\subsubsection{Promoção da eqüidade e justiça}

Para esta condição, admitiu-se que cerca de 20 milhões de habitantes ainda não tinham acesso à energia. Atualmente no Brasil este número está avaliado em 8,6 milhões de habitantes (MME 2010). Esta deficiência se deve ao modelo nacional de geração centralizada, cujos enormes custos de distribuição de energia inviabilizam a chegada de eletricidade a comunidades isoladas, principalmente no Norte do país. A utilização de geração descentralizada a partir de novas fontes de energias renováveis busca sanar este gargalo, ao democratizar o acesso à energia, oferecendo eletricidade a partir de fontes energéticas livres e disponíveis em todo o território, como o vento e o sol. O programa Luz Para Todos do Ministério das Minas e Energia utilizou em pequena escala a geração renovável descentralizada para disponibilizar eletricidade para 11,4 milhões de brasileiros no período de 2004 a março de 2010. A segurança energética só poderá ser alcançada quando os benefícios dos serviços de energia - como luz, aquecimento, eletricidade e transporte - sejam disponibilizados a todos.

\subsubsection{Desvinculação do crescimento econômico e os combustíveis fósseis}

Com a desvinculação entre crescimento econômico e o uso de combustíveis fósseis, o crescimento econômico nacional pode não depender do uso e da exploração de combustíveis fósseis. É necessário fazer uma transição ágil para as novas fontes de energias renováveis de forma a proporcionar um crescimento limpo e sustentável. O mercado mundial de energia renovável é o que mais cresce atualmente, tendo movimentado cerca de 70 bilhões de dólares em 2006; dentre 
todas as formas de geração elétrica, as energias solar e eólica são as que mais geram empregos por quantidade de energia produzida (GREENPEACE, 2007). O uso dos princípios fundamentais que nortearam este estudo é importante para que se possa fazer a análise da inserção de NFER e a eficiência energética, como abordado em seguida.

As novas fontes de energias renováveis apresentam grande vantagem sobre outros recursos energéticos poluentes em vários aspectos. Para tanto, é importante estabelecer a visão de custos completos ou impactos totais no planejamento de recursos energéticos. Nesta ótica devemos analisar recursos energéticos não somente pelos seus parâmetros técnico-econômicos, mas também pelos seus impactos sociais, ambientais e políticos.

É sabido que toda e qualquer forma de geração de energia apresenta algum tipo de impacto ambiental. No entanto, as NFER oferecem as seguintes vantagens: a descentralização, a possibilidade de geração isolada e a diminuição de emissão de poluentes. A geração eólica, solar e as pequenas centrais elétricas pode ser distribuída pelo país em áreas com maior potencial específico, pode suprir a necessidade de comunidades sem acesso a eletricidade e oferece uma alternativa não poluente em substituição a usinas a carvão ou grandes usinas hidrelétricas com reservatórios. A geração distribuída favorece o uso de NFER cujo recurso está presente no local próximo ao consumo, com a vantagem de aumentar a oferta de empregos. Diante disso, ganham importância, para o cenário energético brasileiro, as seguintes renováveis, caracterizadas de maneira abreviada.

- Energia Hídrica: O potencial estimado para geração de pequenas centrais hidroelétricas, segundo a EPE, é de 17 mil MW; na região centro-sul ainda existe um importante potencial para as pequenas centrais hidroelétricas ( $\mathrm{PCHs}$ ) com geração até 30MW. A geração de eletricidade nas hidrelétricas já existentes pode ser aumentada com melhor gestão da água na alimentação da turbina, e na substituição de turbinas e equipamentos obsoletos. Mas a construção de mais hidrelétricas de grande porte com grandes impactos sócio-ambientais vai contra as premissas deste estudo e não está incluída nos resultados do cenário.

- Energia Eólica: Segundo estudo da Associação Brasileira de Energia Eólica, o potencial nacional para este tipo de energia é estimado em 
143 GW, segundo o Atlas Eólico Nacional (AMARANTE; BROWER; ZACK, 2001) Este número deve aumentar consideravelmente com a medição da velocidade dos ventos em alturas maiores e com a inclusão do potencial de geração offshore (instalação de torres de geração no mar). O mercado eólico cresceu cerca de $74 \%$ nos últimos dois anos; economias em desenvolvimento como Índia e China tornaram-se nesta década, respectivamente, terceiro e quinto maiores mercados desta indústria, indicando a viabilidade desta indústria no Brasil. (GWEC, 2009)

- Energia Solar (térmica e fotovoltaica): O uso de energia solar na aplicação térmica está fortemente consolidado, apesar de ainda necessitar de aumento de escala produtiva. Na área fotovoltaica a participação ainda é pequena e os custos ainda são elevados. Entretanto, o mercado mundial cresce a $40 \%$ ao ano e o alto potencial de radiação em todo o território nacional favorece a utilização da geração solar fotovoltaica.

- Biomassa: Oferece amplas possibilidades como forma de contribuição parcial tanto na produção de biocombustíveis como na cogeração a partir de resíduos agrícolas, no uso do descarte de lenha e biogás de lixo urbano. A produção de etanol a partir do uso do bagaço da cana de açúcar tem um importante papel no suprimento da geração elétrica e pode ser feita desde que sejam respeitados os devidos parâmetros sócio-ambientais de sustentabilidade. O desenvolvimento tecnológico e a chegada da segunda geração de biocombustíveis deve reduzir o problema de utilização e impactos ao solo.

Ao lado das energias renováveis, a eficiência energética é uma ferramenta importantíssima na substituição de energéticos poluentes. Para tanto, há diversas possibilidades de aplicação de medidas de eficiência, desde a substituição de equipamentos ineficientes, como lâmpadas, chuveiros, motores e ar condicionado, até programas de combate ao desperdício de eletricidade e uso racional. Outro aspecto importante refere-se ao perfil da demanda elétrica, que pode ser alterada com o uso de tarifas alternativas e armazenamento de energia (em termoacumuladores). Neste caso, os horários de pico de consumo de energia seriam distribuídos, adiando a necessidade de ampliação da geração elétrica nacional. 
Assim, a arquitetura bioclimática conjugaria o melhor uso de iluminação, aquecimento e ventilação naturais, de forma a reduzir a necessidade de eletricidade em residências e edifícios públicos durante o dia. Portanto, o planejamento integrado combinando ações de eficiência energética com o uso de fontes renováveis e o gerenciamento pelo lado da oferta com uso de tecnologias de maior rendimento são ações importantes para garantir uma matriz elétrica com menor emissão de GEE.

\subsection{PRINCIPAIS RESULTADOS DOS CENÁRIOS}

Levando-se em consideração os princípios adotados, foram produzidos cenários com base em modelagens realizadas pelo GEPEA/USP e sob sua supervisão técnica, cenário - referência (Figura 4.3.1).

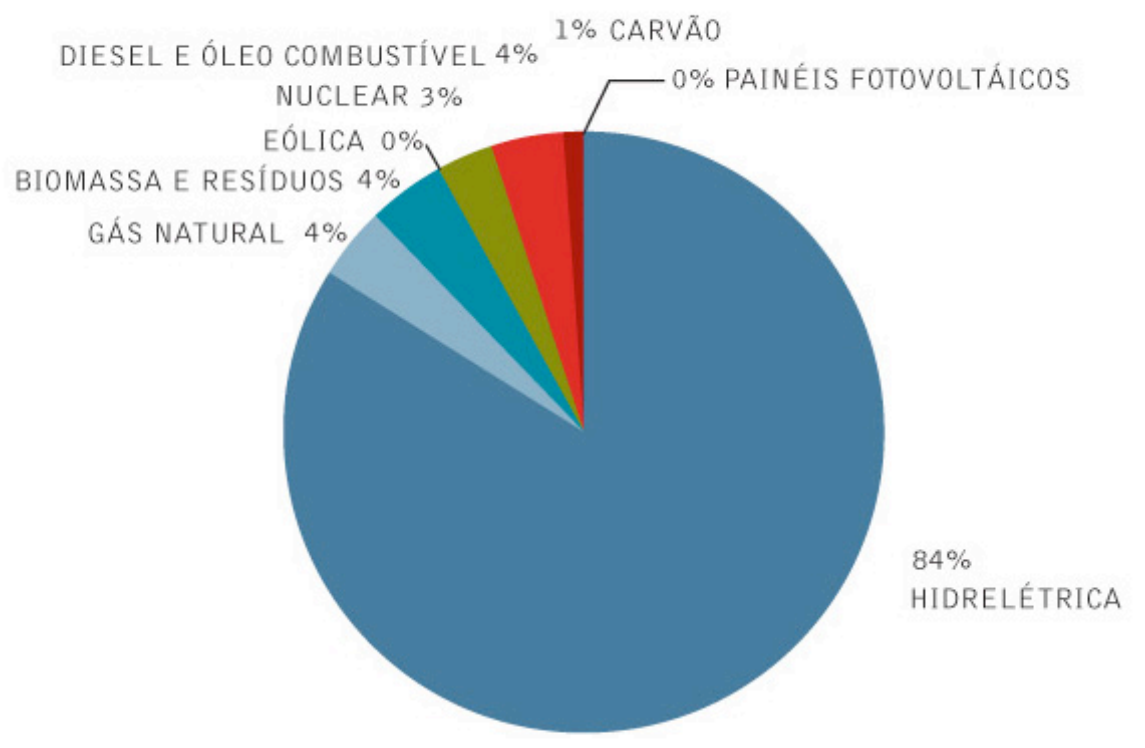

geraçāo total:

367 TWh/ano

Fonte: (Greenpeace Brasil, 2007) Figura 4.3.1 - Geração Elétrica Total - Cenário de Referência 2005

Ambos os cenários foram submetidos às mesmas projeções para crescimento da população e do PIB e, portanto, levaram em conta a mesma projeção de geração de eletricidade para 2050. Os dados para a população seguiram as projeções do IBGE e, para o crescimento do PIB, utilizaram-se os dados da Empresa de Pesquisa 
Energética EPE, que aponta para a taxa de 3,2\% ao ano. A matriz elétrica proposta pela EPE projetado para 2030 quando extrapolada para o ano 2050 pelo GEPEA/USP, apresenta uma geração de 1639 TWh/ano onde a participação das energias renováveis é de apenas $56 \%$ e a contribuição da eficiência energética é desprezível. A matriz elétrica nacional seria composta por $38 \%$ de energia hidrelétrica, uma participação marcante de gás natural (com 34\%), um aumento de geração nuclear para $6 \%$ e geração termelétrica a diesel e carvão de $4 \%$. A energia eólica e biomassa contribuiriam com 4\% e 15\%, respectivamente (Figura 4.3.2).

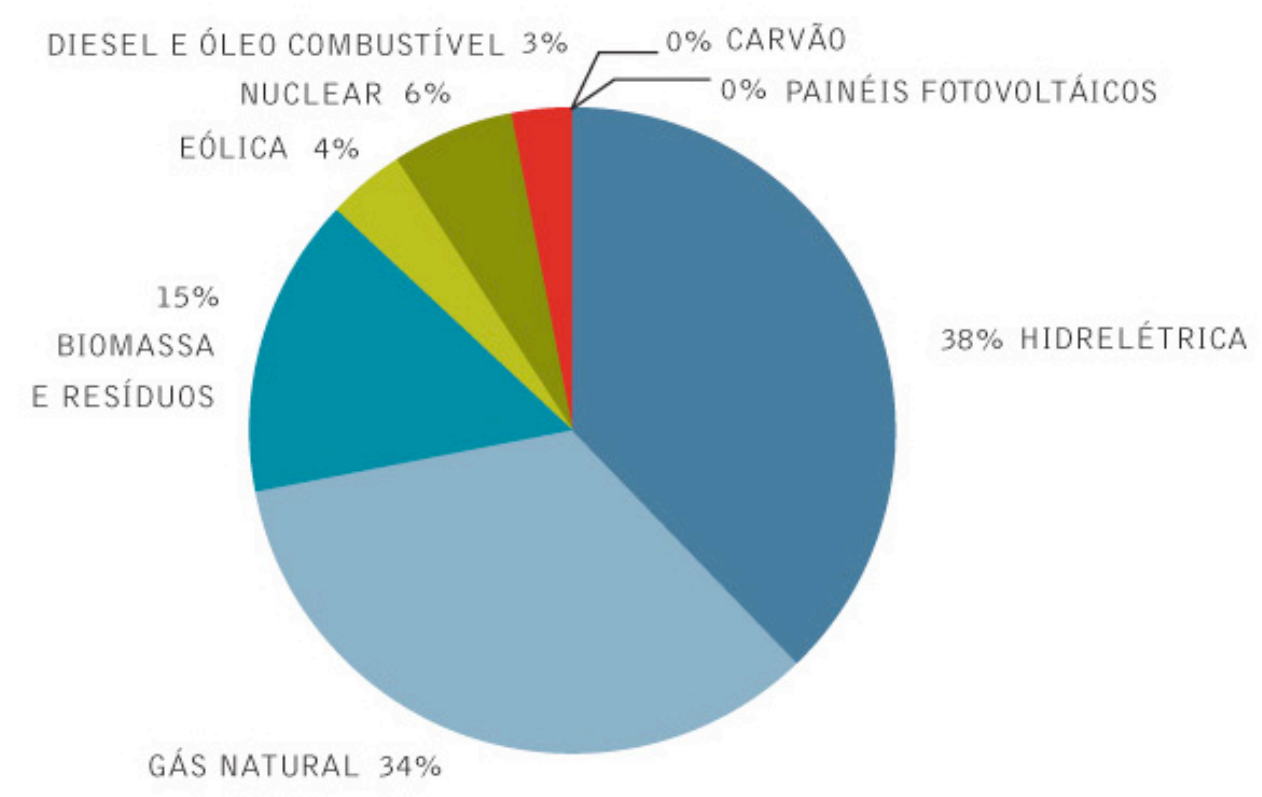

$\begin{array}{lr}\text { geração total: } & 1639 \text { TWh/ano } \\ \text { eficiência energética: } & \text { 0 TWh/ano }\end{array}$

Figura 4.3.2 - Geração Elétrica Total - Cenário de Referência 2050

Fonte: (Greenpeace Brasil, 2007)

Alternativamente, o cenário de [r]evolução energética mostra que é possível desenvolver uma matriz elétrica com 1077TWh/ano de geração e 413TWh/ano em eficiência energética. A participação das renováveis nesta matriz é de $88 \%$ e a carteira de recursos distribuída em 38\% hídrica, 26\% biomassa, 20\% eólica, 4\% solar fotovoltaico (Figura 4.3.3). A geração elétrica a carvão, óleo diesel e nuclear é totalmente eliminada neste cenário. O gás natural complementa a matriz com $12 \%$ de participação. 


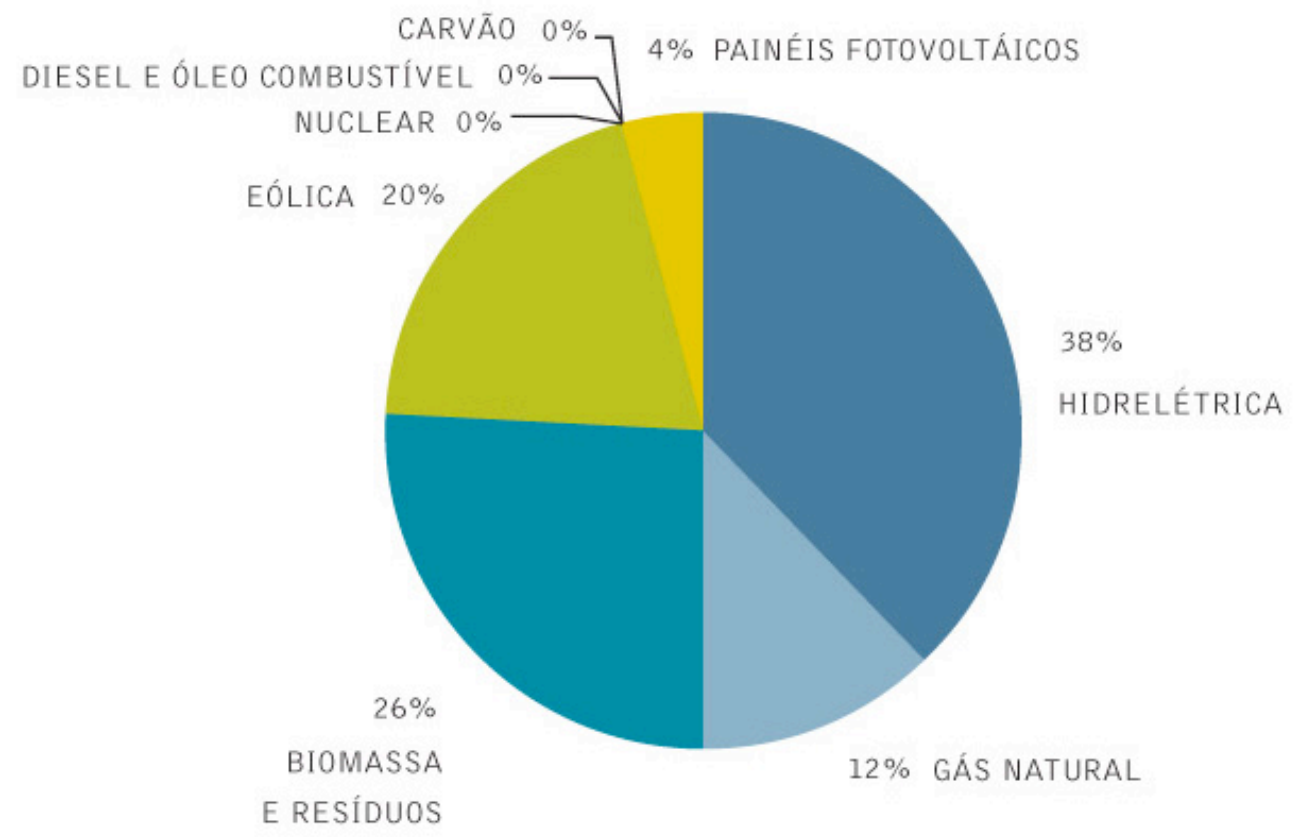

geração total: $\quad 1077$ TWh/ano eficiência energética: 413 TWh/ano

Fonte: (Greenpeace Brasil, 2007) Figura 4.3.3 - Geração Elétrica Total - Cenário [R]evolução Energética 2050

Em termos de custos de oferta de energia, a tendência é de aumento contínuo para suprir uma demanda sempre crescente. No Cenário de Referência, o crescimento da demanda, o aumento dos preços dos combustíveis fósseis e os custos das emissões de $\mathrm{CO} 2$ resultam em um custo de suprimento de eletricidade de 537 bilhões de reais em 2050. Já no Cenário da Revolução Energética obtém-se uma matriz com um custo total reduzido para 350 bilhões de reais em 2050 . No Cenário de Revolução Energética temos cerca de 70 bilhões de reais economizados a partir de programas e medidas de eficiência energética (Figura 4.3.4). No cômputo final, há uma economia de 117 bilhões de reais em 2050, no último ano da projeção. 


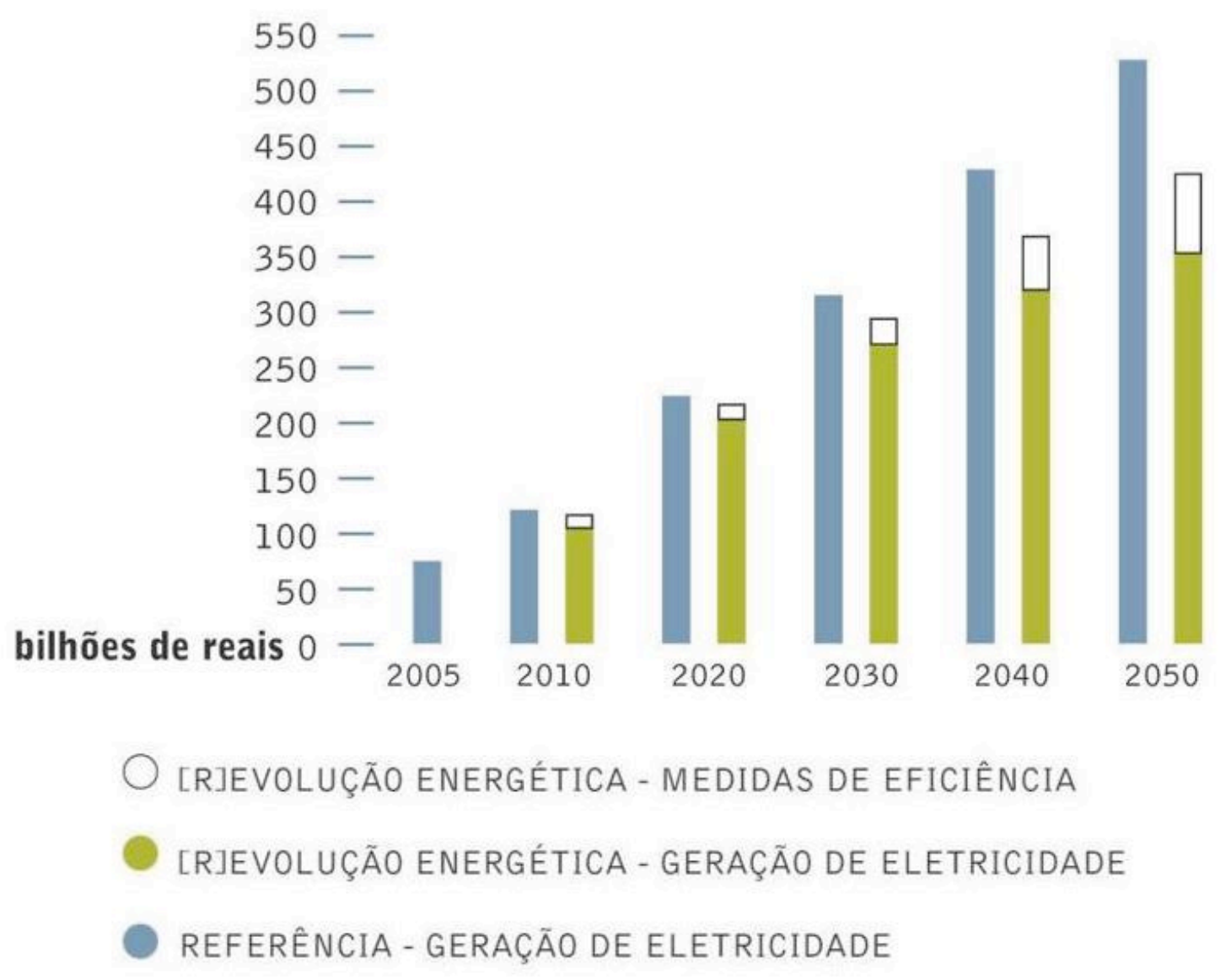

Figura 4.3.4 - Custos Totais de Geração de Eletricidade

Fonte: (Greenpeace Brasil, 2007)

Com relação às emissões de carbono equivalente, estas foram calculadas com base em um fator médio de emissão por tecnologia. O cenário Referencial apresenta os níveis mais elevados de emissões, multiplicando-se por 10 até 2050 . Isso se deve à adoção em grande escala de fontes fósseis. A partir de 2040, com a maturação de tecnologias renováveis, a expansão das emissões é reduzida.

No cenário [r]evolução energética os níveis de emissões em 2050 são bastante reduzidos. O principal fator, é a adoção intensa de medidas de eficiência energética e priorização das fontes renováveis. O cenário [r]evolução energética intensifica a expansão da geração solar e eólica a partir de 2040, fazendo com que suas emissões caiam de forma severa até 2050, tornando-se similares aos níveis apresentados em 2015 (Figura 4.3.5). 


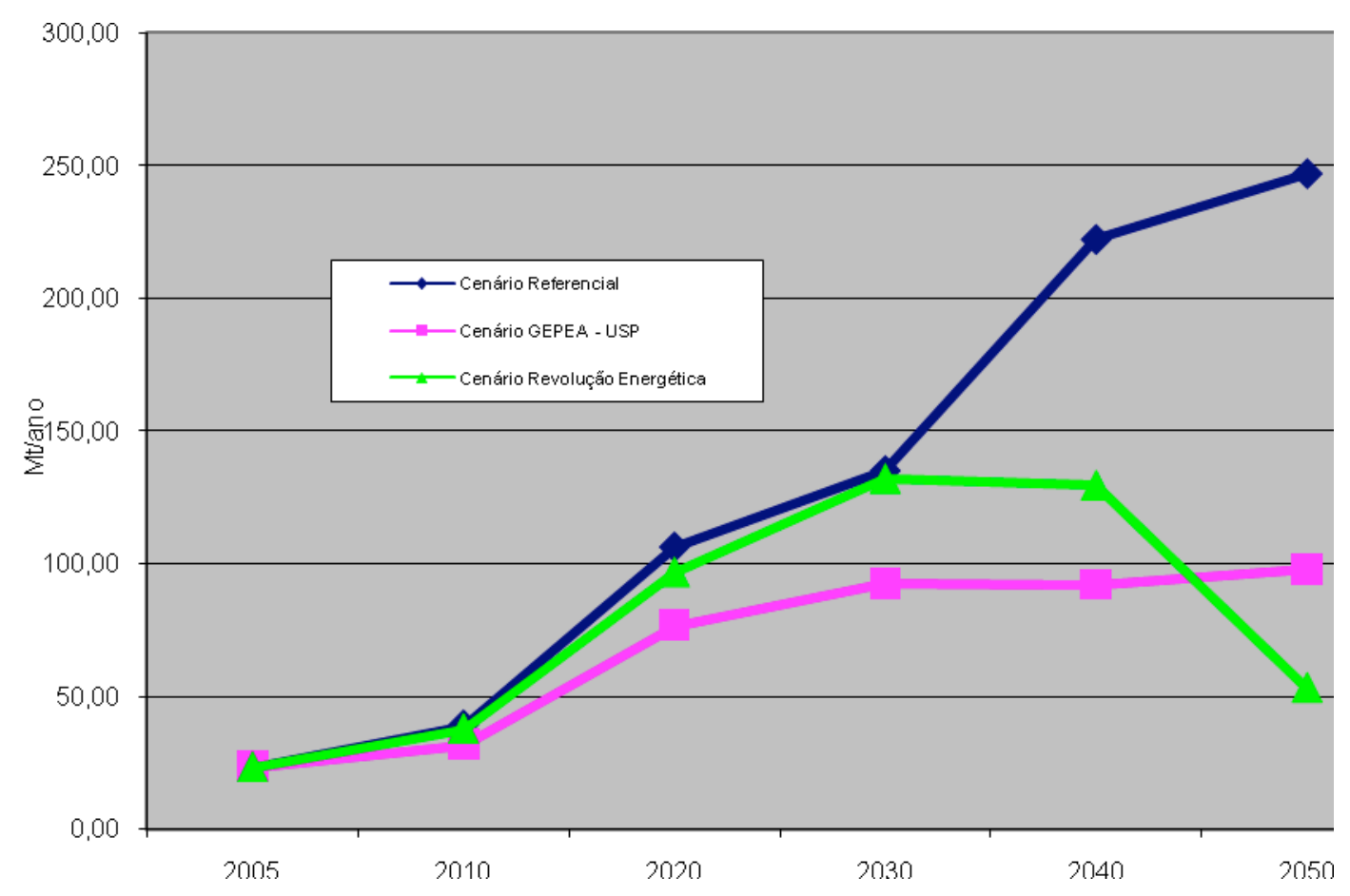

Figura 4.3.5 - Emissão de Carbono Cenário Referência e Cenário [R]evolução Energética

Fonte: (Greenpeace, 2007)

A matriz do cenário de [r]evolução energética cumpre as metas globais de redução de CO2 e ajuda a estabilizar os custos de energia, aliviando, desse modo, a pressão econômica sobre a sociedade. Aumentar a eficiência energética e incrementar a oferta energética proveniente de fontes de energias renováveis resultam, no longo prazo, em uma redução de cerca de um terço dos custos da eletricidade constatados no Cenário de Referência. Fica claro, portanto, que planejar de acordo com metas ambientais rigorosas no setor energético também é uma opção bem sucedida do ponto de vista econômico.

\subsection{DIRECIONADORES PARA A (R)EVOLUCCÃo ENERGÉtICA}

Com o cenário de revolução energética os autores demonstram que é possível atender a demanda futura de eletricidade valendo-se da utilização maciça de energias renováveis. Porém, para garantir a formação deste mercado no país é fundamental seguir as seguintes medidas: 
- Eliminação gradual dos subsídios às fontes sujas como carvão, diesel e energia nuclear e a internalização de seus custos reais (como por exemplo o custo de seguro e descomissionamento de usinas nucleares);

- Definição de metas obrigatórias para a participação das renováveis na matriz brasileira. $\mathrm{O}$ modelo atual com leilões específicos e de reserva para biomassa, $\mathrm{PCHs}$ e eólica ainda não comprovaram ser uma estratégia suficiente para implementar um mercado nacional de NFER pois não há clareza sobre o número e volume de comercialização de energia proveniente destas fontes no futuro. $\mathrm{O}$ atual modelo baseado na mobilidade tarifária desfavorece as renováveis ao priorizar preços baixos de tarifas (NFER são mais caras), segurança de suprimento (renováveis muitas vezes não geram energia de forma contínua), e estabilidade regulatória (a regulamentação das fontes alternativas ainda não é bem clara). No caso específico de energia eólica, inicialmente $o$ índice de nacionalização exigido pelo programa de incentivo a fontes alternativas de energia elétrica (Proinfa) inviabilizou a entrada das fabricantes estrangeiros no país.

- Retorno estável e definido para o investidor no setor elétrico, com contratos a longo prazo e rentabilidade garantida até que as tecnologias estejam competitivas.

- Garantias de acesso prioritário à rede elétrica para as tecnologias renováveis em relação às tecnologias poluentes.

- Padrões de eficiência energética rigorosos para promover a economia e o uso racional de energia, reduzindo a necessidade de novos projetos de geração.

Para que isto ocorra é necessário um novo marco legal no país evoluindo da escala piloto (Proinfa) ou leilões esporádicos, para uma lei com metas mais ousadas que estabeleça outros parâmetros para a formação de preços de fontes energéticas. O financiamento destes projetos pelos bancos de fomento públicos ou privados deve ocorrer segundo a prática do project-finance e não apenas pela garantias financeiras para empréstimos. Outras barreiras à implantação deste mercado podem ser identificadas, como a falta de vontade política de estimular o setor, repercutindo na falta de um ambiente regulamentado e na ausência de investidores internacionais. 
Pode-se somar a este pacote o quase desconhecimento da indústria sobre a evolução da área de renováveis e a ausência de linhas de transmissão em diversas áreas do país onde se pretende instalar geradores eólicos e centrais a biomassa. A ausência da internalização dos custos ambientais nas diversas fontes de energia retira uma vantagem competitiva das NFER.

As oportunidades já detectadas para o desenvolvimento do mercado de renováveis são, entre outras: o grande potencial nacional de energias renováveis; o baixo índice de emissão de gases efeito estufa; o curto tempo de implementação de projetos; a geração de empregos nas tecnologias renováveis; o crescimento da demanda elétrica em pelo menos três vezes até 2050 , gerando forte demanda sobre a utilização de tecnologias novas; e a crescente consciência e interesse de consumidores de energia elétrica em utilizarem energias não poluentes em residências e edifícios. Em síntese, pode-se dizer que o sucesso deste mercado e da composição de uma matriz elétrica limpa baseada em novas fontes de energias renováveis e eficiência energética depende de um esforço conjunto entre o governo e a sociedade. 


\section{CAPÍTULO 5 - MODELOS DE MERCADO PARA COMERCIALIZAÇÃO DE ENERGIA}

\subsection{INTRODUCC̃̃O}

Neste capítulo serão discutidos os distintos modelos de mercado nos quais a comercialização de energia pode ser praticada. A definição de um modelo de comercialização é fundamental para a estruturação e viabilização de empresas de energia envolvidas com geração ou comercialização de fontes renováveis. Neste capitulo analisaremos os principais modelos utilizados no setor elétrico.

\subsection{MONOPÓLIO}

A principal modelagem, desde o surgimento da indústria do setor elétrico ainda no século XIX, foi a do monopólio natural, ou em todas as atividades da cadeia de eletricidade (geração, transmissão e distribuição), normalmente com a integração vertical das mesmas. Usualmente, o regime tarifário é baseado no custo do serviço. Não há competição entre os geradores, e tampouco os distribuidores podem optar por um fornecedor de energia.

Uma variação que pode surgir desse modelo é a existência de diversas empresas de distribuição (cada uma com sua área de concessão) que detêm os monopólios de rede e vendas no varejo, mas que, por outro lado, estão sujeitas ao monopólio de compra da energia, por um único proprietário da geração.

Segundo Mello (MELLO, 2003) esse modelo apresenta baixíssimo grau de risco para os agentes, pois existem muitas garantias: consumidores não migram de empresas de fornecimento, outros geradores não surgem no mercado para deslocar os antigos agentes e a tarifa remunera todos os custos. Não há a noção de "preço" e sim de "custo". 
Ainda segundo Mello (MELLO, 2003) a eficiência econômica dificilmente é atingida nesse modelo, pois qualquer decisão errada de investimento (seja na seqüência de obras ou na opção de tecnologia) pode ser repassada para os consumidores na tarifa de energia, criando assim poucos incentivos para a redução de custos.

A principal vantagem que esse modelo apresenta, para a visão de um gestor estatal ou público, é a facilidade de implementação de políticas sociais (i.e., a implementação de obras e/ou programas que eventualmente podem não ser financeiramente atrativos), diante da possibilidade de repassar os custos desses programas aos consumidores via tarifa.

\subsection{COMPRADOR ÚNICO}

Este modelo é caracterizado pela existência de um agente que exerce o poder de monopólio de toda energia gerada e centraliza a venda dessa energia para distribuidores e clientes finais.

Pode existir competição apenas no segmento de geração quando existe superávit de produção e/ou quando são incentivados os Produtores Independentes de Energia. A figura 5.3.1 sintetiza esta modelagem.

Toda a venda de energia para as empresas de distribuição é feita pelo agente comprador, que deve aplicar uma tarifa que reflita os custos marginais de curto prazo. Essa tarifa estaria garantindo a eficiência econômica, pois a demanda estaria sendo suprida pelo custo incremental das fontes existentes no sistema de geração. Esta tarifa também deverá cobrir os custos operacionais do comprador, ou seja, a administração da compra e venda de energia (MELLO, 2003).

Segundo Mello (MELLO, 2003) a questão do acesso à rede de transmissão passa a ter um papel mais importante, de modo a facilitar a competição na atividade de geração. Passa a ser fundamental a divulgação de determinadas informações, como por exemplo, as responsabilidades de conexão, operação, padrões de equipamentos para controle, medição, bem como os preços para o acesso.

Alguns aspectos relativos à eficiência e riscos merecem destaque. A maior parcela dos custos em um sistema de geração de energia elétrica está concentrada 
nos custos de investimento na atividade de geração, aberta à competição. A necessidade de firmar contratos (PPAs) com o comprador central e a abertura a novos entrantes são incentivos suficientes para a busca de maior eficiência na construção das novas centrais.

O estudo da Andrade \& Canellas (MELLO, 2003) analisa que a gerência de riscos é relativamente facilitada, pois ao firmar um contrato com o comprador central, um gerador garante a sua remuneração, reduzindo a sua exposição a novos geradores. Além disso, esse contrato reduz a ameaça que novas tecnologias poderiam trazer à sua central, supondo-se que ele estará contratado por prazo suficiente para pagar totalmente a sua central. Para o gerador não existe o risco de mercado, pois uma vez acertada a venda de energia para o comprador central, esse fica com a responsabilidade de repassar a energia para as empresas de distribuição.

Essa estrutura também permite a implementação de políticas sociais. 0 comprador único detém o monopólio sobre os consumidores (empresas de distribuição) podendo, dessa forma, repassar qualquer custo necessário à implantação de uma política, como por exemplo, ações de desenvolvimento de uma determinada região do país, incentivo a um tipo específico de combustível, ou ainda outras políticas públicas. Cabe ao regulador evitar que ineficiências desse agente sejam repassadas aos consumidores finais.

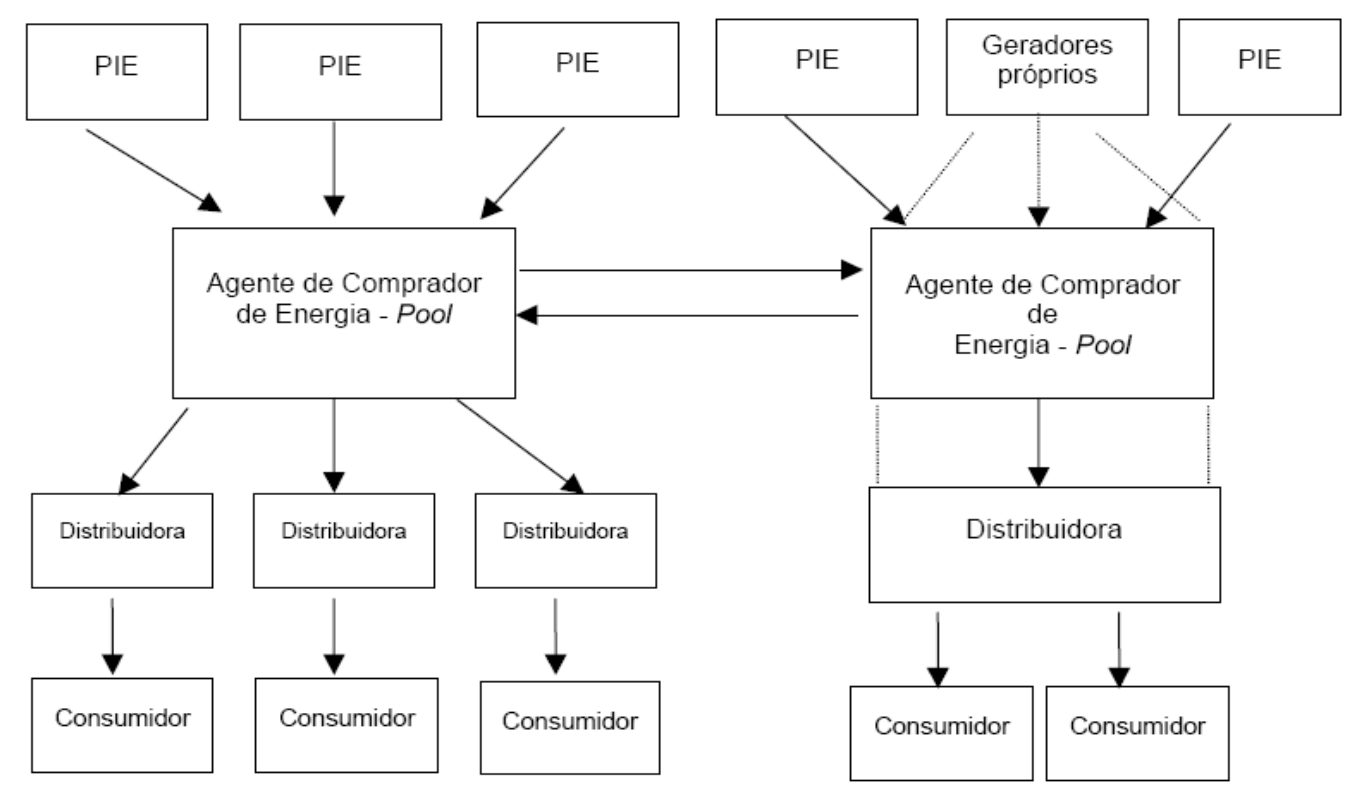

Figura 5.3.1 - Modelo de Comprador Único

FONTE: (BANDEIRA; MENEZES, 2003) 


\subsection{COMPETICÃ̃O NO ATACADO}

O modelo de competição no atacado permite o livre acesso ao sistema de transmissão e as distribuidoras podem escolher de qual geradora desejam comprar a energia. Mello (MELLO, 2003) complementa a análise deste modelo pela proposição de que o agente comprador pode coexistir com a competição no atacado.

As Figuras 5.4.1 e 5.4.2 apresentam esta sistematização, respectivamente sem e com a figura do comprador centralizado.

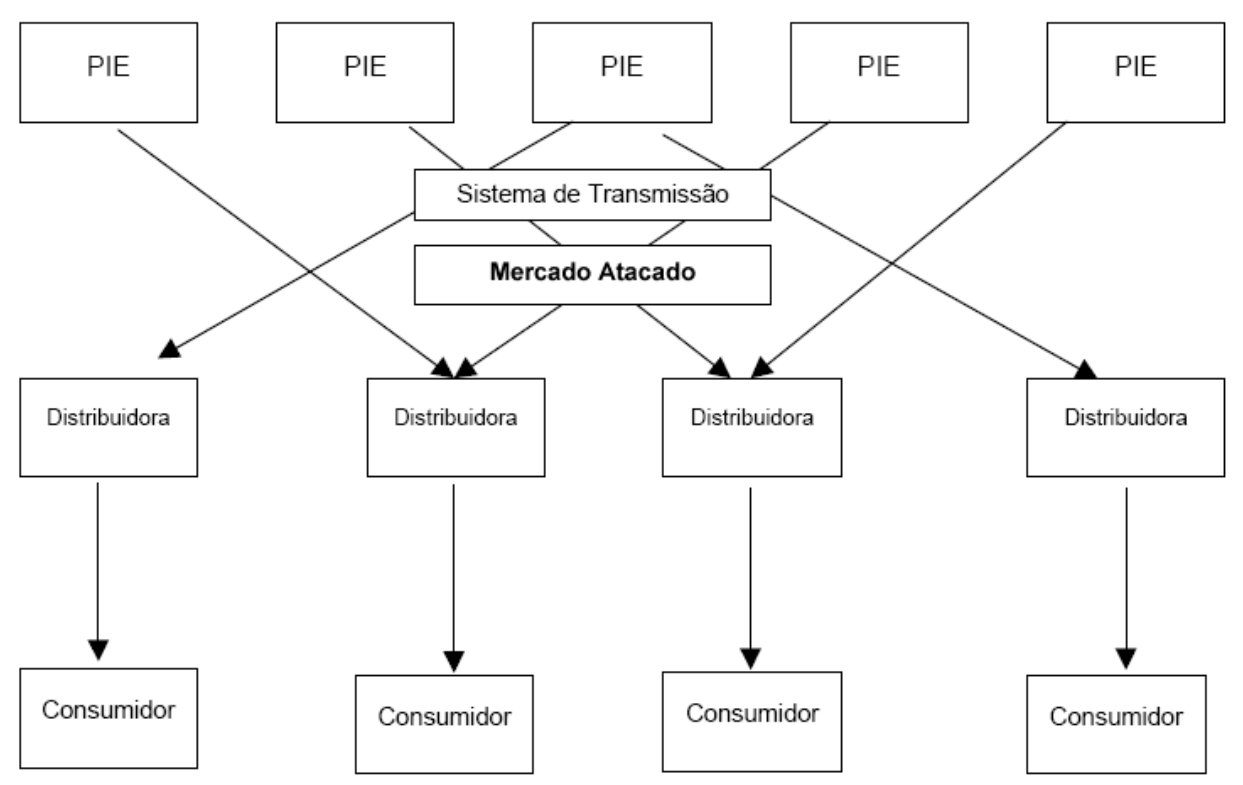

Figura 5.4.1 - Modelo de Competição no Atacado

Fonte: (BANDEIRA;MENEZES, 2003)

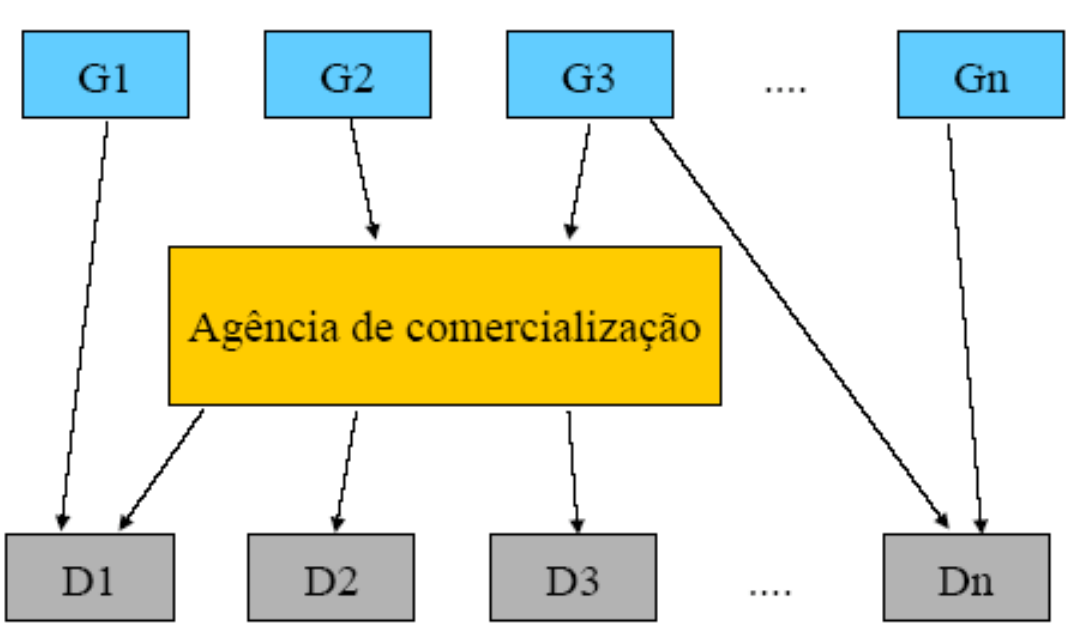

Fonte: (MELLO,2003)

Figura 5.4.2 - Modelo de Competição no Atacado com Agente Comprador 
Nesse caso, tal como foi recomendado pelo projeto RESEB da Coopers \& Lybrand, é necessária a total separação das atividades de geração e comercialização do negócio de transporte, seja ele na transmissão ou distribuição. Essa separação é recomendável para garantir o livre acesso às redes de transporte e evitar a ocorrência de subsídios cruzados através de estratagemas de uma empresa verticalizada que propicie ganhos importantes em um dos segmentos em detrimento a outros, criando assim barreiras a o acesso a novos entrantes.

A função de comercialização (MELLO, 2003) é nova nesse modelo, sem a necessidade de propriedade de ativos. Além disso, é importante que haja a liberdade de entrada e saída do mercado para geradores e comercializadores, de modo a se aproximar de um mercado competitivo. Um agente comercializador não necessita deter a propriedade de nenhum ativo, seja ele de geração ou transporte. $O$ comprador central neste modelo dá lugar ao operador do mercado (ou pool), que tem a função de atender ao sistema do ponto de vista comercial, garantindo que todos que tenham disposição a pagar pela energia possam efetivamente recebê-la.

O estudo da ABRACE (MELLO, 2003) destaca a necessidade da separação das atividades de operação técnica e comercial. A responsabilidade sobre a instalação de medição, seus padrões e o fluxo de informações entre geração e carga deverá ser claramente definida entre os proprietários de geração, transmissão, distribuição e o operador do mercado.

Outro ponto a ser considerado é a elevação dos custos de transação à medida que um maior número de relações comerciais for estabelecido entre os diversos agentes. Isso provavelmente se traduzirá em uma vantagem para grandes consumidores, pois eles possuem maior escala para negociar sua energia. Para o caso de pequenos consumidores, a alternativa poderá residir em uma organização para facilitar a negociação de compra e venda de energia ou então a manutenção da sua condição de monopolizados. Essa organização dificulta sobremaneira a implantação de políticas sociais, a menos que haja um processo de consideração explícita das suas necessidades e a quantificação dessas medidas. 


\subsection{COMPETIÇÃO NO VAREJO}

O modelo de competição no varejo permite que a competição se estenda aos consumidores finais, ou seja, no varejo. Cada consumidor pode escolher seu fornecedor havendo livre acesso às redes de transmissão e de distribuição. Neste modelo a competição se estende às atividades de comercialização e também às de geração. Esta modelagem está reproduzida na Figura 5.5.1 subseqüente.

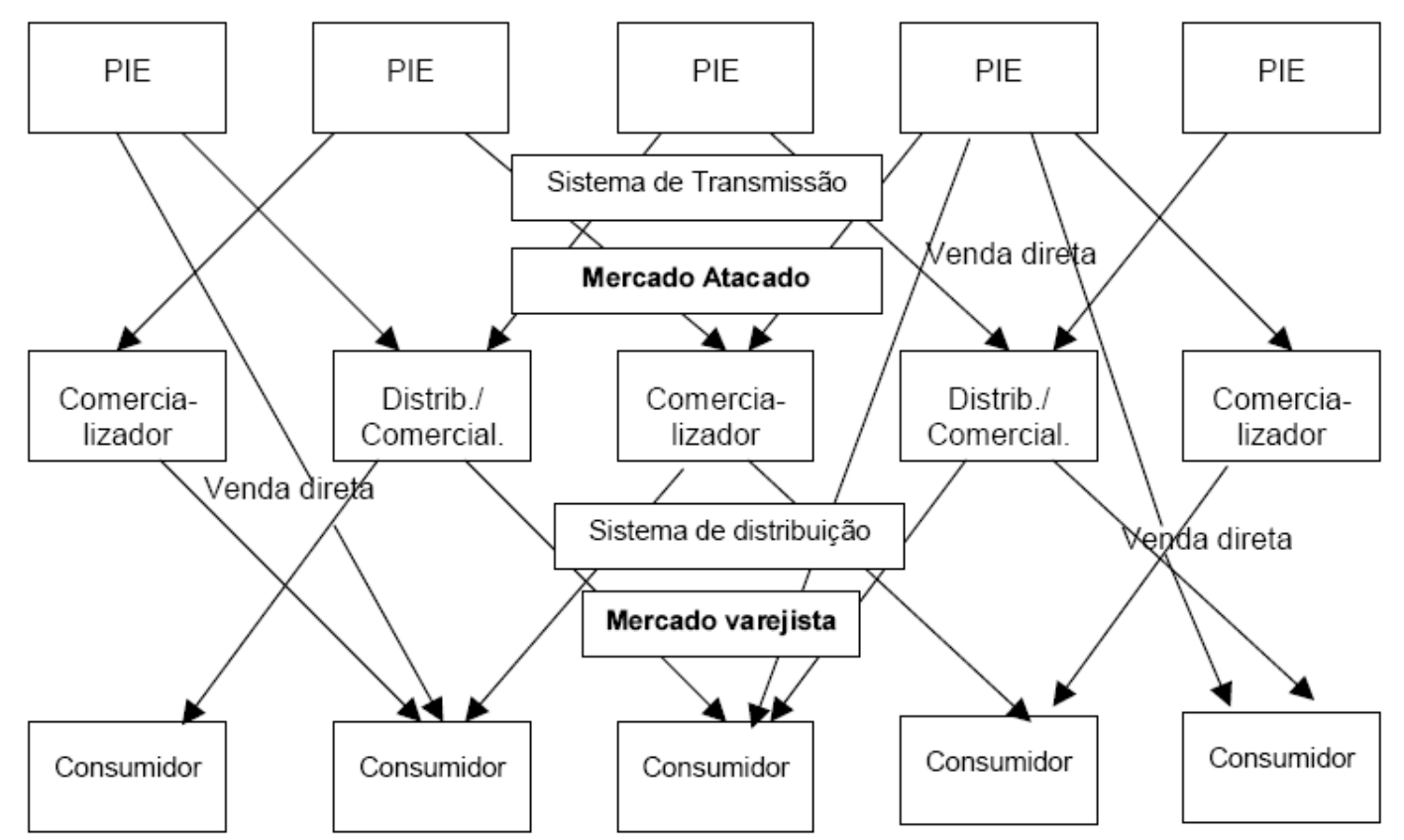

Figura 5.5.1 - Modelo Competição no Varejo

\subsection{REFORMAS DO SETOR ELÉTRICO MUNDIAL}

Os modelos descritos representam uma evolução decorrente de muitas reformas ocorridas nos principais países desenvolvidos, em alguns casos por razões ideológicas como no Reino Unido onde se desejava afastar o Estado dos negócios e em outros por necessidades de atratividade para o capital privado visando investimentos especialmente em geração.

De forma geral todos os principais países programaram mudanças no setor elétrico. A Figura 5.6.1 apresenta uma cronologia das principais reformas ao longo 
do mundo. Embora não se possa afirmar que estivessem presentes em todas as situações e tempos as principais características foram:

- Ampliação da competição nas atividades de geração.

- Maior liberdade para participação do capital privado na expansão.

- Sistema aberto na transmissão.

- Implantação de novas sistemáticas de operação e regulação.

- Liberdade de escolha no segmento consumo com diferentes níveis de participação no atacado e no varejo.

- Transferência de propriedade dos ativos existentes (privatização).

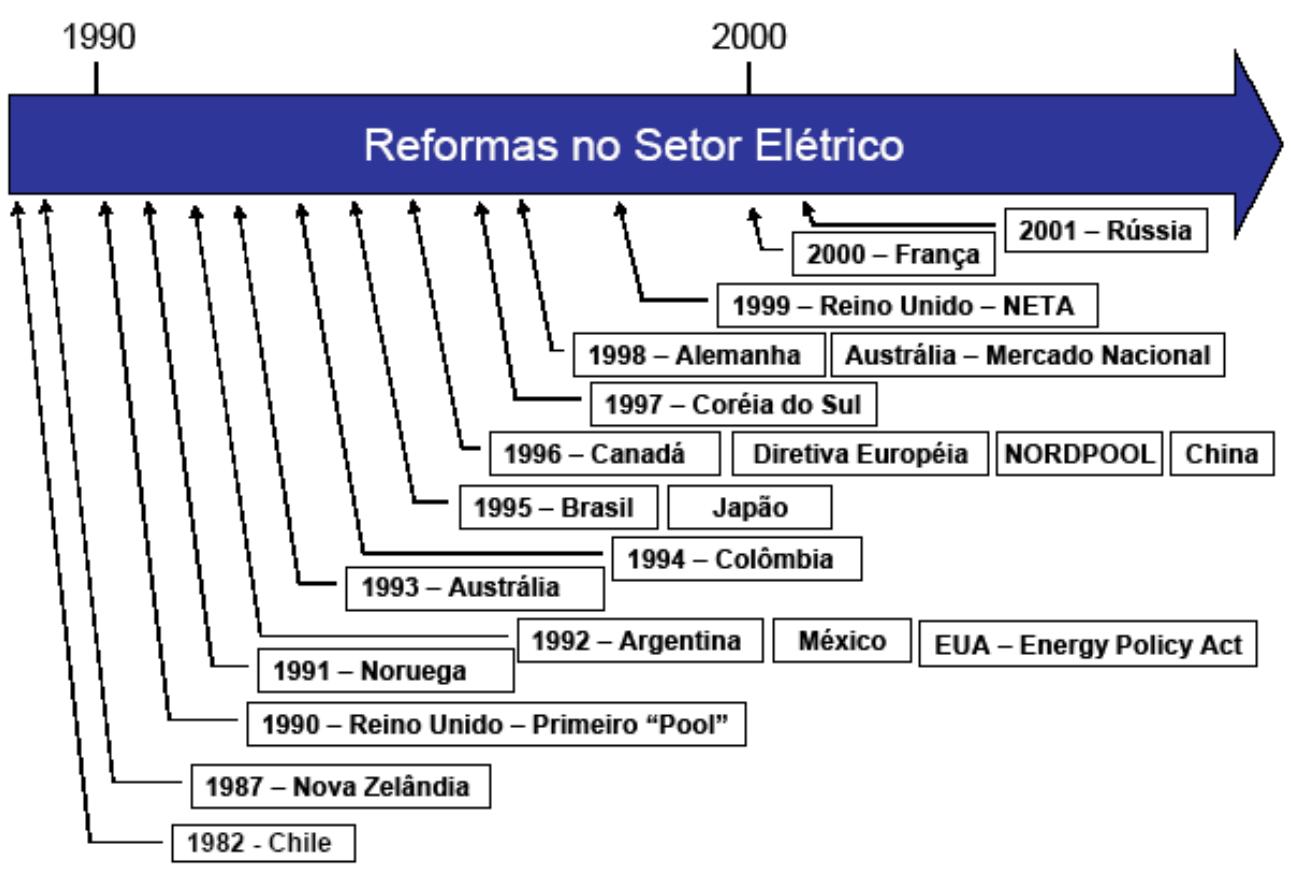

Figura 5.6.1 - Cronologias das Reformas no Setor Elétrico

Fonte: (MELLO, 2003)

No Brasil, a lei 9074/95 estabeleceu em 1998, a possibilidade de competição aos consumidores que tivessem demanda contratada superior a $10 \mathrm{MW}$ e conexão com tensão superior ou igual a $69 \mathrm{kV}$. Passados 3 anos, os limites foram reduzidos para $3 \mathrm{MW}$ sendo mantidas as regras de conexão e tensão. Consumidores com ligação posterior à data da edição da lei de concessões (7 de julho de 1995) não possuem restrições relacionadas com o nível de tensão, apenas a exigência relacionada a uma demanda mínima de $3 \mathrm{MW}$.

Posteriormente a lei 10.438/02 criou a oportunidade de migração ao mercado livre para consumidores com demanda mínima de $500 \mathrm{~kW}$, sem restrições de tensão, desde que a fonte produtora fosse classificada como especial, ou seja, energia 
renovável (PCHs, PCTs de biomassa, Centrais eólicas ou solares). Em ambas as opções de contratação, ou seja, energias incentivadas ou provenientes de grandes usinas se faz necessário que o contrato de fornecimento com a distribuidora no mercado cativo tenha se encerrado. É exatamente neste nicho de mercado que se concentram as oportunidades para uma comercializadora de energia renovável.

Quando se analisa a visão mundial, a percepção é de que se caminha gradualmente para um ambiente de total liberdade, atingindo inclusive os mercados de baixa tensão e o da classe residencial.

Mello (MELLO, 2003) apresenta uma visão consolidada dos critérios de elegibilidade na Europa, conforme Figura 5.6.2 subseqüente.

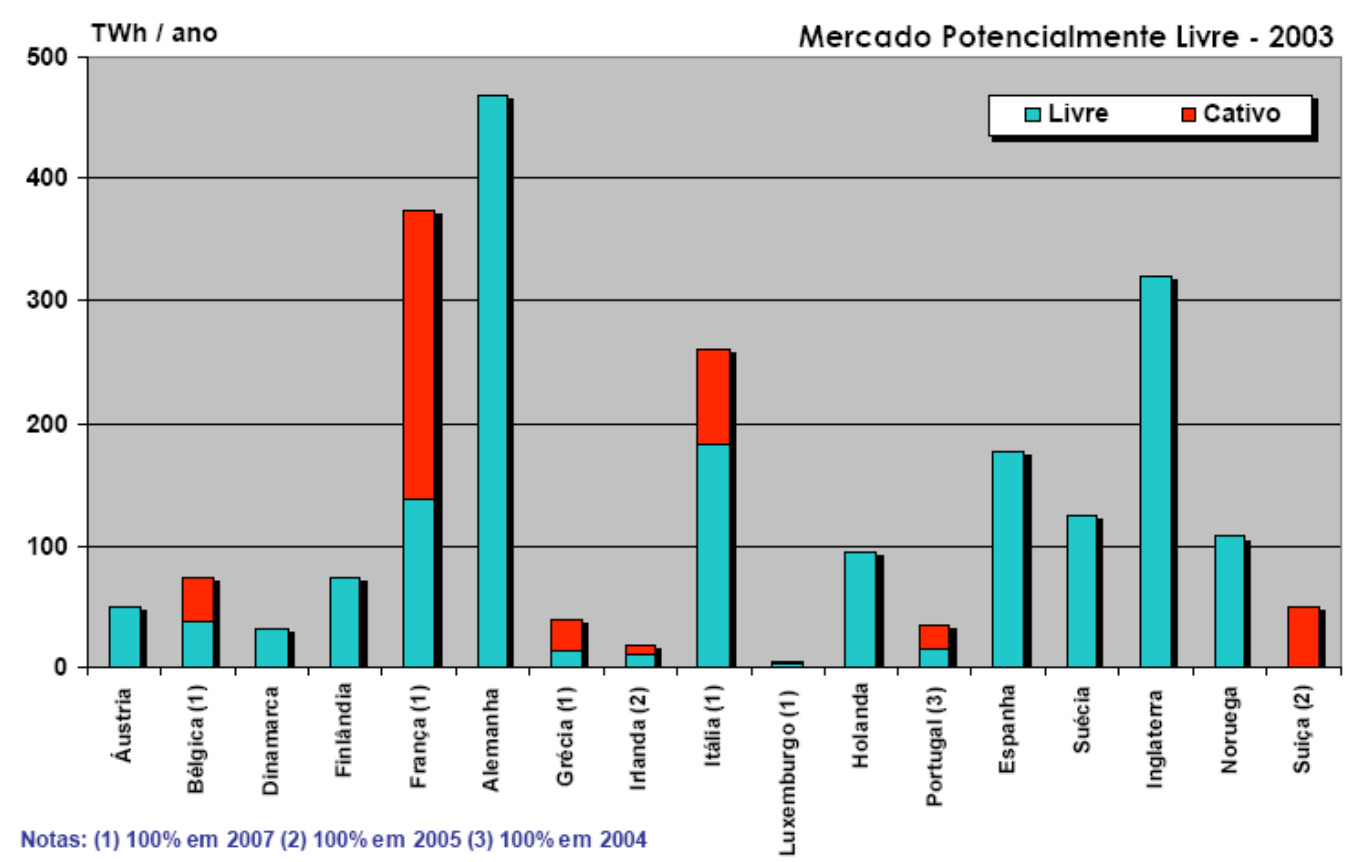

FONTE: (MELLO, 2003)

Figura 5.6.2 - Mercado Elegível na Europa para Livre Competição na Eletricidade

Outras referências indicam que agentes de mercado possuem posicionamentos diferentes sobre a viabilidade de um mercado baseado em NFER. Algumas das opiniões encontradas na literatura (DAMME; GIJSBERT, 2002) indicam que estes mercados apenas irão se desenvolver se existirem fortes políticas de incentivo; se os governos promoverem incentivos à competição e ao mercado livre de energia; e que apenas se viabilizarão com ações mandatórias dos governos.

Quando se tratar da criação de um mercado competitivo em campos de atividades onde antes existisse apenas uma atividade monopolista, não são suficientes declarações de que por razões do interesse público este mercado 
passaria a ser declarado "aberto", quando seria quase inevitável a participação intervencionista do governo, como acontece, aliás, na quase maioria dos mercados.

Na verdade a questão relevante não diz respeito à ocorrência ou não de uma intervenção regulatória em um mercado, especialmente no mercado de energia e mais especficamente no mercado de energia limpa. A questão central diz respeito à forma com que esta intervenção acontece. (Damme;Gijsbert, 2002)

Portanto, a combinação de um modelo de competição no varejo com abertura de mercado incorporando a baixa tensão e a classe residencial, e políticas de governo que ampliem a competição na geração com novas sistemáticas de operação e regulação formariam condições ideais para a comercialização de energia elétrica proveniente de NFER no Brasil. 


\section{CAPÍTULO 6 - EXPERIÊNCIAS INTERNACIONAIS COMERCIALIZAÇÃO DE ENERGIAS RENOVÁVEIS}

\subsection{INTRODUCC̃̃O}

Este capítulo apresenta uma série de modelos de políticas públicas utilizadas na Europa, nos Estados Unidos, China e Índia com uma breve análise dos principais pontos e os fatores de sucesso. Esta análise oferece elementos que podem ser incorporados no modelo brasileiro baseado nas experiências exitosas ao redor do mundo.

As iniciativas de governos de países que decidiram implementar políticas públicas e instrumento de mercado para estimular o desenvolvimento de novas fontes de energias renováveis constituem importante benchmarking para lideranças brasileiras e a reflexão das pessoas que ocupam cargos governamentais com poder decisórios.

Relatório produzido por Baitelo, com a colaboração de Almeida Prado e Furtado (Greenpeace, 2008), contém a análise de modelos de mercado para instalação de um mercado de energia renovável em vários países do mundo para contribuir na discussão de uma estratégia para o Brasil.

\subsection{MOdelo Adotado na AlemanHA}

O Governo alemão elaborou importante modelo de utilização de energia solar, a biodiesel e energia eólica, alcançando $10 \%$ da matriz energética do país em 2005.

O modelo resultou no rápido crescimento do mercado eólico com base no instrumento de política pública denominado Electricity Feed-In Act, de 1991, com as seguintes características essenciais, muitas dessas representando novidades no país: 
- Garantia de compra de energias renováveis pelas concessionárias, o que era novidade no país.

- Fixação de preço mínimo e obrigação de conexão da energia limpa na rede de distribuição

- Conseqüente redução de compra de energia convencional.

Houve encarecimento do custo e repasse para o consumidor. Além disso, os concessionários alegaram a inconstitucionalidade da lei, o que levou à revisão e reformulação do marco regulatório em 1998

Em 1998, a lei sofreu sua primeira revisão, após ter sua constitucionalidade questionada pelas concessionárias, que discordavam do sistema Feed-in.

A expansão do mercado de eólicas e o grande número de projetos e de instalação de usinas desse tipo de energia fez com que o governo reduzisse o preço prêmio e que estabelecesse o teto de compra de energia renovável.

A partir de então foi criado novo marco regulatório, representado pela Lei de Energias Renováveis, Renewable Sources Act, visando estimular a continuidade dos empreendimentos eólicos.

Foi, então, estabelecido novo modelo de compartilhamento de custos para os geradores e distribuidores, na tentativa de equilibrar o mercado em todos os níveis da rede nacional de distribuição de energia.

$\mathrm{Na}$ ocasião, buscou-se estabilizar a competitividade para os outros tipos de energia utilizados no país, porém, com metas e níveis diferenciados para redução das tarifas para as energias limpas que compunham o sistema.

O plano alemão adotou o crescimento da oferta das energias renováveis:de $5 \%$ em 2000 e 10\% em 2010. Adicionalmente, ficou estabelecida a revisão bienal das tarifas e modificação das metas para participação das energias renováveis na matriz nacional. Dessa maneira, ficou definido, em 2004, o aumento da meta de $10 \%$ para $12,5 \%$ em 2010 e de $20 \%$ em 2020.

Paralelamente, ficou decidido o descomissionamento - até 2020 - de 17 usinas de energia nuclear em funcionamento, acompanhado da redução no consumo de energia da ordem de $3 \%$ ao ano.

Por conta disso, o setor eólico quase triplicou; Passou de 6.100 MW de potência instalada em 2000 para 16.630 MW, em 2004.

O sucesso do modelo da Alemanha apoiou-se no binômio investimento público e mercado, movimentando, em 2006, € 21,6 bilhões, sendo apenas $€ 2$ 
bilhões de recursos públicos. Em 2009, a Alemanha situava-se entre os três maiores geradores de energia eólica no mundo, com capacidade instalada de $25.777 \mathrm{MW}$.

\subsection{MOdELO AdOTAdo NA ESPANHA}

O envolvimento da Espanha - tradicionalmente adepta da energia hidrelétrica - para a expansão da matriz energética e orientação para energia renovável, foi estimulado pela crise do petróleo, nos anos 70 . Os principais marcos de referência, no país, são listados em seguida.

- Implantação do Centro de Estudos de Energia, posteriormente chamado de Instituto de Diversificação e Economia Energética, e que teve papel relevante para os programas energéticos no país.

- Decreto Real 2.366, em 1994, tornando obrigatória a oferta, pelas concessionárias, de energia renovável, a preço reduzido, durante 5 anos.

- Liberação do mercado energético, em 1998, tornando-o competitivo, a partir da harmonização do regime de incentivos.

- Estabelecimento, em 2000, de metas para participação de fontes renováveis, com base no Plano para a Promoção de Energias Renováveis na Espanha: 12,0\% de renováveis na matriz energética e 29,4\% na geração elétrica até 2010 .

O mercado de eletricidade reagiu bem, e o segmento de energia eólica se expandiu no país, mesmo diante de incertezas sobre a duração do apoio ao sistema tarifário. Os geradores tiverem liberdade para vender a energia renovável, em 2004, apoiados em política pública focada na redução de custos e aumento da eficiência; concessão de prêmio diferenciado sobre preços de mercado. (COSTA,C.V. 2007)

As conseqüências foram importantes: a capacidade eólica instalada em 1993, de apenas $52 \mathrm{MW}$, chegou a 19.149 MW, ao final de 2009. A Espanha tornou-se um dos maiores geradores do mundo e deve superar as metas esperadas para 20 mil MW em 2010, graças, em especial, ao modelo de incentivos regionais para instalação de fábricas eólicas. E o resultado não poderia ser outro: geração de empregos e facilidades de financiamento de bancos. 


\subsection{MODELO ADOTADO NA ESLOVÊNIA}

O incentivo para as iniciativas do governo da Eslovênia em direção às metas de renováveis surgiu da Diretiva 2001/77/EC do Parlamento Europeu. Com isso, sugeriram situações interessantes.

- Introduziu-se o modelo de sistema híbrido de modalidades de tarifas feed-in.

- Alcançou-se $30 \%$ de participação de energias renováveis na geração elétrica nacional, com previsão de chegar a 33\% até final de 2010 .

- Criou-se tarifas diferenciadas para capacidade instalada das plantas e diferenciação por tipo de biogás (combustível) utilizado.

- Houve liberdade de venda no mercado e instrumento de prêmio para a energia renovável.

Na Eslovênia, os produtores têm garantia de compra de energia na tarifa fixa, mas podem receber maior preço pela eletricidade, dependendo do período do ano, especialmente no caso da geração por biomassa e biogás, amplamente utilizadas no país.

A Eslovênia aderiu, em 2007, juntamente com a Alemanha e Espanha, ao estímulo do modelo feed-in cooperativo, no âmbito internacional, promovido pela Conferência Internacional de Energias Renováveis de Bonn, em 2004. (International Feed In Cooperation 2009).

\subsection{MOdELO Adotado NA ÍNDIA}

A Índia é importante exemplo na expansão das energias renováveis, tornando-se um dos mercados mais promissores do mundo para a energia renovável, cuja capacidade instalada de eletricidade passou de 1,4 GW, em 1947 para 159 GW, em 2009. 
A deliberada ação do governo indiano e a disponibilidade de estoque de biomassa, radiação solar, potencial eólico e de pequenas centrais hidrelétricas são fatores decisivos para o desenvolvimento deste mercado.

A meta da política indiana de energias renováveis era de atingir uma capacidade instalada de $10.000 \mathrm{MW}$ até 2012; a capacidade instalada apenas em eólica já ultrapassou este valor ao final de 2009. O mercado já estima que o número para renováveis será o dobro, $20.000 \mathrm{MW}$.

O crescimento da geração de renováveis e as razões para a atração dos investidores são, principalmente:

- o grande aumento da demanda e subjacente problema causado pela poluição derivada do uso de energia fóssil.

- infraestrutura pública para os investimentos privados e, como resultado, a presença dos principais fabricantes mundiais de aerogeradores e oferta de aeroturbinas, na Ásia.

Os instrumentos de mercado, utilizado pelo governo indiano, são reduções e isenções de impostos, recursos para projetos-piloto e empréstimos para empreendimentos.

A infraestrutura institucional, criada pela Lei da Eletricidade, de 2003, fortalece e promove as energias renováveis através de tarifas preferenciais e obrigação de contratação mínima para distribuidoras.

O mercado de eletricidade indiano chega a US\$ 3 bilhões e cresce à taxa de $20 \%$ ao ano, com investimentos públicos e privados. Assim, a indústria eólica se beneficia e ganha estabilidade, com capacidade instalada de $10.926 \mathrm{MW}$, sendo que metade deste valor foi instalada nos últimos 4 anos. Com isso, a Índia figura entre os cinco maiores mercados de energia eólica mundial.

Estes fatos foram essenciais para atração de grandes empresas e a produção nacional, em que algumas companhias já fabricam $80 \%$ de seus componentes nacionalmente (MALLON et al., 2006).

\subsection{MOdelo Adotado NA CHINA}


A política energética chinesa é baseada na Lei de Energia Renovável para aumentar a competitividade da energia eólica em relação às fontes fósseis e que passou a vigorar no início de 2006, com as seguintes características.

- Meta legal para o desenvolvimento de energias renováveis em alta escala.

- Suporte tarifário.

- Fabricação local de aerogeradores .

- Construção de parques eólicos de 100 MW, via processo de licitação, com os objetivos de reduzir custos de geração e aumentar a proporção de componentes fabricados localmente.

Os resultados não tardaram.

- São mais de quarenta empresas locais envolvidas na fabricação de turbinas que atendem mais da metade do mercado chinês.

- Duplicação da capacidade eólica instalada entre 2005 e 2006.

- Terceiro maior mercado mundial, com 25.805 MW. A meta original de atingir 5.000 MW até 2010 foi alcançada em 2007. O mercado dobra de tamanho a cada dois anos e agora espera-se alcançar 127.500 MW de capacidade instalada até o fim da década (Global Wind Energy Council, 2010).

\subsection{MODELO ADOTADO NA ESTADOS UNIDOS}

A indústria eólica iniciou-se em 1978, mas, teve altos e baixos, por conta de instabilidades e descontinuidades em condutas públicas, marcos legais e regras de mercado, caracterizando-se dois ciclos notórios.

O início foi marcado pela implementação da PURPA (Lei de Políticas Regulatórias de Concessionárias), como parte da Lei Nacional de Energia. Neste momento a lei buscava eliminar três problemas principais (Almeida Prado, F; 2006): a energia cogerada e ou produzida em instalações do pequeno produtor não era comprada pelas concessionárias; as tarifas de reservas suplementares de potência eram elevadas e desestimulavam a cogeração; e a comercialização de energia 
elétrica no sistema americano tinha custos administrativos e burocráticos elevados. Com a regulamentação da lei o governo federal introduziu várias ações.

- Obrigação das concessionárias para aquisição de toda a energia renovável gerada por pequenos produtores.

- Diversificação da matriz com a elegibilidade das fontes renováveis como eólica, hidráulica, biomassa, incluído o lixo urbano e aproveitamentos fotovoltaicos.

- Aumento da eficiência energética pela inserção de plantas de cogeração

- Melhoria na confiabilidade do sistema da concessionária pelo aumento do numero de fontes de geração de energia

- Implementação do PURPA e estabelecimento do preço destas energias pelos estados.

O esquema ISO 4 (Interim Standard Offer), criado pelo governo da Califórnia, destacou-se sobremaneira, por estabelecer garantia, por 30 anos, que a energia gerada por produtores seria comprada pelas concessionárias.

De 10 MW de energia eólica instalada em 1982, a produção passou para 1.039 MW em 1985. Fixação de tarifa e aumento no preço do petróleo reduziram a competitividade das usinas térmicas a combustíveis fósseis.

Em 1992 o governo norte-americano institui o Crédito do Imposto de Produção (PTC), que garantia uma dedução de 1,8 centavos de dólar para cada kWh produzido por energia renovável. O PTC teve seu prazo expirado duas vezes, o que resultou em ciclos de alta e baixa geração (1687 MW de eólicas acrescentado em 2003 contra apenas 389 MW no ano seguinte).

Incentivos criados pelo PTC favoreceram empresas com grande "apetite fiscal" e cooperativas rurais, que se tornaram produtoras de energia eólica, não eram suficientemente lucrativas para se beneficiarem dos créditos do instrumento.

O modelo dos EUA diferiu do adotado na Europa, onde a indústria renovável foi essencialmente construída por novos atores do setor energético.

Nova modalidade de política para energias alternativas surgiu nos anos 90 , reconhecida como Renewable Portfolio Standard (RPS) ou Padrão de Carteira Renovável, com os seguintes contornos.

- Ganhos em competitividade, em parte como reflexo da transformação do mercado de energia nesta época. 
- A evolução dos preços com base no mercado livre e criação do sistema de créditos de energia renovável.

- Adoção obrigatória por todas as concessionárias.

- Flexibilidade no cumprimento das metas.

- Possibilidade de empréstimo e créditos de renováveis.

- Penalização nos casos de não cumprimento.

O exemplo mais bem sucedido de aplicação do RPS foi no Texas, desde 1999. Atualmente, os Estados Unidos lideram a geração eólica no mundo, com 35,159 MW instalados ao final de 2009, dos quais $10 \mathrm{mil} \mathrm{MW}$ foram adicionados nesse ano, a despeito da crise financeira mundial.

O modelo atual norte-americano promoveu o desenvolvimento do parque eólico, mas não incentivou a indústria local: sete das dez maiores indústrias eólicas mundiais estão sediadas na Europa (Dinamarca, Espanha e Alemanha). Apenas uma está nos Estados Unidos.

\subsection{MODELO ADOTADO NA REINO UNIDO}

O apoio político para o desenvolvimento das energias renováveis foi instituído em 1989, pela Lei da Eletricidade (Electricity Act), mas, não foi acompanhado de instrumentos de mercado apropriados.

Isto se refletiu no mercado. O Governo privatizou o setor elétrico e ofereceu apoio à geração renovável, mas também à geração nuclear, através da Obrigação de Combustíveis Não-Fósseis (Non Fossil Fuel Obligation - NFFO). Os incentivos financeiros públicos, alocados ao desenvolvimento das energias renováveis, derivaram de pequena parte da taxa de carbono, a Fossil Fuel Levy, que era aplicada à geração fóssil. A maior parte era direcionada para o subsídio à energia nuclear. Para exemplificar, com base nos dados de 1990: 7,8 bilhões de libras para energia nuclear e apenas 400 milhões de libras para as renováveis.

Assim, o parque energético inglês consolidou-se, basicamente, como térmico (carvão e gás natural) e nuclear, embora o Reino Unido disponha do melhor potencial de energia eólica da Europa.

Outros aspectos marcaram a política do Reino Unido. 
- Divisão de recursos para as principais renováveis.

- Contratos a longo prazo, redução gradual de preços fixados para cada tecnologia e disponibilização do maior volume de energia ao menor preço através de leilões.

- O maior problema do instrumento foi o domínio da pressão competitiva sobre os demais objetivos da política. Os projetos competiam entre si, mas no final não eram construídos. Houve especulação e práticas predatórias de preços e os leilões geraram um ciclo de altos e baixos que minou a estabilidade e as perspectivas da política.

Marco legal importante ocorreu em 2002, quando a NFFO foi finalmente substituída pelas Obrigações a Renováveis (Renewables Obligation - RO).

A RO criou créditos de renováveis, reconhecidos como importante subsídio para a energia eólica e criou instrumentos para negociação entre as concessionárias de forma que as metas de comercialização de energia renovável pudessem ser alcançadas.

A efetividade das ROs não é reconhecida com certeza, em relação ao mercado local. Mas, os resultados para expansão do parque eólico não podem ser ignorados. O Reino Unido é um dos dez maiores geradores de energia eólica, com 4.051 MW - dos quais $810 \mathrm{MW}$ foram instalados em 2009. Em novembro deste mesmo ano, o parlamento inglês aprovou a nova legislação (Energy Act 2010) que introduz a tarifa feed-in para a geração de energia renovável. A meta do governo é alcançar uma participação de $15 \%$ de renováveis na matriz elétrica em 2015, aumentando para $20 \%$ em 2020. 


\section{CAPÍTULO 7 - NOVO MARCO REGULATÓRIO PARA PROMOVER AS NOVAS FONTES DE ENERGIAS RENOVÁVEIS NO BRASIL}

\subsection{INTRODUÇÃO}

Este capítulo discute uma proposta de marco regulatório ideal para fomentar um mercado de novas fontes de energias renováveis no Brasil. Inicialmente, o capítulo apresenta o histórico das energias renováveis no Brasil e posteriormente discute modelos de políticas públicas adotados nos principais mercados de energias renováveis. Em seguida discute a atual legislação Proinfa e as possibilidades futuras e por fim propõe um marco regulatório ideal para implementação de uma comercializadora de energia elétrica a partir de NFER.

\subsection{ENERGIAS RENOVÁVEIS NO BRASIL}

Comparativamente à situação atual, as ações do Governo Brasileiro, nos últimos 20 anos, para o setor energético, tanto com relação a marcos políticos como estratégias econômico-financeiras têm sido limitadas. O novo Plano Decenal de Expansão Energética, PDE 2010-2019 apresenta uma expansão de termelétricas movida a combustíveis fósseis mais reduzida em relação ao plano anterior. Entretanto, ainda mostra um crescimento incompatível em um país com tanto potencial de energia renovável.

Marco Legal - PL do Senado 27/1996 e Substitutivo ao Projeto de Lei 2905-2000

O Projeto de Lei do Senado 27/1996 de autoria do Senador Edson Lobão criou o Programa de incentivos a Energias Renováveis - PIER. O programa promovia a geração eólica, fotovoltaica e termo-solar para sistemas isolados de pequeno porte. O programa visava atender a população desfavorecida pelo atendimento convencional de energia com uma opção renovável. A opção solar 
visava substituir chuveiros elétricos por sistemas termo-solares. O projeto foi considerado inconstitucional na Comissão de Constituição e Justiça e de Cidadania da Câmara dos Deputados em 2009.

O Substitutivo ao Projeto de Lei 2905-2000 tinha autoria do Poder Executivo e como relator o Deputado Federal José Carlos Aleluia. A lei proposta permitia a ANEEL autorizar a implantação de geração independente por fontes alternativas como solar, eólica, biomassa e PCHs. A lei permitia a diferenciação dos valores de referência de geração para fontes renováveis. A lei foi considerada uma importante iniciativa para a inserção das fontes alternativas de energia no sistema elétrico nacional. Em 2003 a Mesa Diretora da Câmara dos Deputados solicitou a retirada deste projeto pela Presidência da República e teve o pedido deferido (DUTRA, R.M. 2001).

\section{Marco Legal - Proinfa}

Com o objetivo de aumentar a geração de energia elétrica a partir de energias renováveis, foi estabelecido o Programa de Incentivo às Fontes Alternativas de Energia Elétrica (Proinfa) com base no Artigo $3^{\circ}$ da Lei 10.438 de 26 de abril de 2002, contemplando a energia eólica, de biomassa, e de Pequenas Centrais Hidrelétricas (PCHs). A geração solar fotovoltaica não foi incluída no programa.

A estratégia adotada foi a de inserção de pequenos produtores para atuação no mercado de energias renováveis; a adoção do modelo feed-in para introdução da energia gerada no SIN (Sistema Interligado Nacional); o sistema de cotas, como o leilão de projetos de energia renovável por cotas de potência para cada tecnologia envolvida; e linhas de crédito subsidiadas do Banco Nacional de Desenvolvimento Econômico e Social (BNDES) (SZKLO; FELISBERTO, 2004).

Na prática, o piso para aquisição de energia renovável pelo chamado VETEF Valor Econômico correspondente à Tecnologia Específica de cada Fonte foi limitado a $80 \%$ do valor da tarifa média nacional ao consumidor final. Com isso, foram estabelecidos - pelo Ministério de Minas e Energia e pela Eletrobrás ${ }^{13}$, os valores diferenciados para geração hidrelétrica $R \$ 128 / M W h$ e de $R \$ 110 / M W h$ para biomassa (bagaço de cana), R\$ 135/MWh para PCHs e entre R\$ 208 e $R \$$ 240/MWh para eólicas (variáveis de acordo com o fator de capacidade, entre 32,4\% e 41,9\%).

\footnotetext{
${ }^{13}$ Eletrobrás - Centrais Elétricas Brasileiras S.A., empresa de economia mista e capital aberto sob controle acionário do governo brasileiro, controla empresas de geração ,transmissão e distribuição de eletricidade.
} 
Os preços foram considerados baixos, pelos investidores, havendo casos em que os valores não cobririam os custos de produção. Por isso, o leilão de cotas não teve o sucesso desejado. Em leilão realizado em agosto de 2008, a energia de biomassa atingiu o valor de $\mathrm{R} \$ 128 / \mathrm{MWh}$.

O incentivo de financiamento também não promoveu resultados satisfatórios.

- Limite de até $70 \%$ para financiamento pelo BNDES e exigência de garantias reais, o que inviabilizava os projetos.

- Ineficácia da ação da Eletrobrás, no contrato de compra de energia de longo prazo (PPAs), que asseguraria ao empreendedor uma receita mínima de $70 \%$ da energia contratada durante o período de financiamento e proteção integral quanto aos riscos de exposição ao mercado de curto prazo. Esta porcentagem foi posteriormente aumentada para $80 \%$, a fim de viabilizar mais projetos e aprimorar o desempenho do programa.

- Ineficácia do princípio de $60 \%$ de nacionalização de empreendimentos energéticos, previsto na Lei 10.438/02. Posteriormente, o índice foi flexibilizado para viabilizar projetos eólicos, ainda dependentes de equipamentos importados.

- Medidas regulatórias foram complementadas pela Lei 11.075, de 30 de dezembro de 2004, estendendo os prazos de celebração de contratos e de início de funcionamento de empreendimentos, previsto para 2006, mas prorrogados para o final de 2008, nos contratos firmados pela Eletrobrás até 30 de junho de 2004.

Independentemente do Proinfa, como marco legal que previu as condições e meios para o desenvolvimento da energia eólica, a energia solar fotovoltaica encontrou elementos para iniciativas através do PRODEEM (Programa de Desenvolvimento Energético dos Estados e Municípios).

O propósito era atender as comunidades com o uso da energia solar e a decisão da ANEEL de regulamentar os sistemas individuais de geração de eletricidade com fontes intermitentes. As regras foram mais flexíveis, quanto à duração dos contratos. Hoje, o maior programa nacional é o da COELBA (Companhia de Eletricidade da Bahia), que já atende a 8 mil consumidores, regularmente. 


\subsection{Modelos de Políticas de Desenvolvimento de Fontes Renováveis}

As lições aprendidas na implementação dos modelos adotados nos principais mercados de energias alternativas fornecem informações importantes para a formulação de políticas públicas e criação de instrumentos de mercado para o parque brasileiro de novas fontes de energias renováveis.

Os seguintes elementos são recomendados:

- Análise institucional dos principais mercados de energias alternativas.

- Leis de incentivo para garantia de remuneração justa aos geradores.

- Previsão de benefícios diretos e indiretos a cada fonte na matriz energética, na geração de energia limpa e nos efeitos periféricos resultantes da criação e da sustentação de mercados.

- Tarifas feed-in adequadas, capazes de combinar instrumentos de incentivo a subsídios e flexibilização de impostos relacionados a equipamentos e serviços da cadeia de geração de energias renováveis.

\subsubsection{Tarifa feed-in}

A tarifa feed-in merece atenção especial, como preço especial pago pelas concessionárias de energia para a eletricidade proveniente de fontes renováveis.

- Amplamente utilizada, com sucesso, na Europa, está na raiz do mercado de energia eólica na Europa (principalmente em países como Alemanha e Espanha) e Ásia (China e Índia).

- Suporta grandes mercados de energia renovável a um custo pulverizado entre todos os consumidores de eletricidade.

- As tarifas feed-in - quando fixas - definem e garantem o preço mínimo da energia. Quando são estabelecidas como prêmio, pagam um valor adicional além do preço de mercado. As tarifas prêmio flexibilizam o preço frente ao mercado.

- Podem ser diferenciadas, como ocorre na Espanha, onde é usada como opção de sistema de recompensa pré-fixada, ou mecanismos de 
"bônus ambiental". Neste caso, a tarifa funciona pela adição de uma recompensa somada ao preço básico de venda da eletricidade. Neste caso, os mecanismos beneficiam tanto o investidor como o consumidor, pela flexibilidade de integração da tarifa no mercado global de eletricidade já que os envolvidos responderão a sinalizações do próprio mercado (Greenpeace, European Renewable Energy Council 2007).

- Tarifas regulamentadas por obrigações contratuais como o pagamento de valores fixos por 20 anos, nos casos da Alemanha e Espanha, oferecem mais segurança aos investimentos e atraem novos investidores. A tarifas devem cobrir os custos da geração, margem razoável de lucro e preço acessível ao consumidor de energia que motive o investidor a aplicar seus recursos. No caso das renováveis, a tarifa feed-in pode se basear nos custos de geração de energia ou nos custos externos evitados pela utilização de fontes renováveis tais como emissões de gases estufa.

- A tarifa pode ser complementada com subsídios do Governo, condicionando a obrigação da aquisição da eletricidade apenas à quantidade de energia perdida na transmissão e distribuição, como ocorre na Estônia e na Eslováquia. Na Espanha, República Tcheca, Dinamarca e Eslovênia, a energia renovável é vendida diretamente no mercado spot. Os produtores recebem o preço de mercado somado a um prêmio para cada kWh comercializado (KLEIN ET al., 2008).

- Tarifas também podem variar com o tamanho da usina de geração e do combustível utilizado. Pode haver redução gradual da tarifa, com a incorporação da curva de aprendizagem evitando a sobre compensação. Visando a manutenção da política energética e o monitoramento fino da variação de preço da energia, as tarifas são revistas regularmente. Por exemplo, a tarifa de energia solar fotovoltaica, é reduzida em cerca de $5 \%$ ao ano como reflexo direto da redução de custo pela curva de aprendizado da tecnologia.

\subsubsection{Sistema de Cotas/Certificados Verdes}


O sistema de cotas é uma política na qual o governo define um modelo de mercado com produção, venda e distribuição de uma quantidade mínima fixada de energia e as fontes renováveis a serem priorizadas. $O$ modelo de cotas protege as fontes renováveis de eventual competição por outras fontes de menor custo. Para evitar distorções de mercado as cotas podem ser comercializadas entre companhias.

- No sistema de cotas, o controle de aquisição de certificados verdes garante o equilíbrio entre as cotas crescentes de geração e consumo de energia limpa para as concessionárias ou para o consumidor final. O valor do certificado é adicionado à tarifa de eletricidade para garantir que o custo da geração renovável seja incorporado ao preço de mercado praticado.

- O sistema é utilizado em países europeus como, Bélgica, Romênia, Suécia, Itália e, até recentemente, o Reino Unido, além de vários estados norte-americanos, onde é conhecido como Padrão de Portfólio Renovável ou Renewable Portfolio Standard. Nos EUA existe um forte pleito do setor de energias renováveis por um portfólio nacional para viabilizar a demanda de que $10 \%$ de toda a eletricidade seja proveniente de energias renováveis até 2012 e 25\% até 2020 .

- O sistema de cotas é compatível com o uso da tarifa feed in, de acordo com diferentes análises internacionais (RICKERSON; GRACE, 2007). Esta combinação é comum na Europa; enquanto que nos Estados Unidos, o mecanismo mais utilizado dentro do sistema RPS é o de licitação.

\subsubsection{Sistema de licitação e leilão}

Os procedimentos de licitação são utilizados em geral quando o governo tem interesse em definir a quantidade de energia a ser gerada e a potência instalada para cada fonte renovável assim como sua taxa de crescimento. Os critérios de avaliação da oferta são normalmente determinados antes de cada licitação através 
de documento público. A licitação é utilizada para fomentar investimento em tecnologias ou regiões específicas.

Existem processos mais competitivos, como sistemas de leilões. Nestes, se organiza um processo de competição entre produtores para geração de um determinado montante de energia renovável. As propostas são selecionadas a partir daquelas ofertadas com menor preço até completar o total a ser contratado. Os contratos de compra são em geral de longo prazo, específicos por fonte renovável e elaborados sobre o preço final do leilão. Os contratos podem prever a construção e operação do projeto específico.

A Irlanda, França, Dinamarca e Reino Unido utilizaram este sistema para promover a energia eólica. No Reino Unido, no período de 1990-1998 funcionou o sistema de Non-Fossil-Fuel Obligation ou Obrigação de Combustíveis Não-Fósseis onde empreendedores ofereciam lances para diferentes tecnologias renováveis. Atualmente ele é utilizado na Irlanda e de forma híbrida, utilizando elementos de tarifas feed-in na França e no Brasil.

O sistema competitivo é usado em alguns casos para empreendimentos de grande porte, e o esquema "feed-in" é empregado para projetos de pequena escala como na Califórnia e Washington (COUTURE; CORY, 2009) e proposto recentemente no Brasil, pela Comissão Especial de Energias Renováveis.

A incorporação de características do sistema feed-in como a obrigação de contratos de longo prazo e a conexão dos empreendimentos à rede garantiram aos leilões realizados no Brasil um resultado mais positivo do que no Reino Unido. Entretanto, o maior problema identificado no país é a falta de remuneração de um preço justo à energia ofertada, como resultado da competição entre empreendedores. O fracasso dos leilões na Califórnia com contratos fechados com lances baixos, sem que os empreendedores tivessem as condições financeiras de desenvolver os projetos apontam para as vantagens da atuação das tarifas feed in na implementação de projetos de grande porte (GRACE et al., 2008). 


\subsubsection{Subsídios e medidas fiscais}

Os subsídios como taxas especiais para investimentos ou medidas fiscais na forma de créditos em impostos ou na redução de pagamentos podem ser um mecanismo importante para superar barreiras de um investimento com alto custo inicial, como no caso de empreendimentos em tecnologias de energias renováveis menos econômicas. A forma de incentivo pode ter maior ou menor impacto político se o ônus econômico é feito sobre o contribuinte em geral ou diretamente do consumidor de eletricidade (TESKE, 2005).

A redução ou abatimento em impostos especiais aplicados na geração, a isenção tributária para fundos verdes e utilização de fundos específicos para geração limpa são exemplos de utilização do sistema fiscal para promover fontes renováveis.

Os créditos de impostos ou Production Tax Credits (PTC) são utilizados nos EUA e no Canadá desde 1992 (MALLON, 2006). O PTC concede um desconto de 1,8 centavos de dólar no imposto de renda para cada kWh produzido em parques eólicos. Este índice é reajustado anualmente pela inflação. No recém celebrado pacote anti-crise aprovado pelo governo norte-americano - o Ato de Recuperação e Investimento (American Recovery and Reinvestment Act) prorrogou o PTC (originalmente programado para expirar ao final de 2008) e ampliou a concessão de crédito, ao fornecer pagamentos de $30 \%$ dos custos totais de investimentos em projetos.

República Tcheca, Reino Unido, Chipre (nos quais a política é adicional a outras medidas de incentivo), Finlândia e Malta (que a utilizam como único instrumento de fomento ao mercado) também utilizam incentivos fiscais como medida política de incentivo a renováveis.

A grande deficiência dos créditos fiscais tem sido a inadequação dos períodos de crédito com os prazos de implementação de projetos de energia renovável. Os prazos restritos tem comprometido a estruturação da indústria de componentes e seu custo. Estes efeitos comprometem a efetividade deste mecanismo na promoção estável de energias renováveis a custos mais baixos (MALLON, 2007). Um exemplo disto é a opção temporária de crédito oferecida pelo ARRA, válida apenas para projetos que iniciem sua construção entre 2009 e 2010 (ZINDLER, 2009). 
A concessão de crédito pode ser combinada com a tarifa feed in. O custo do capital inicial dos projetos podem ser reduzidos através de incentivos fiscais e consequentemente os valores de tarifa necessários para viabilizar estes empreendimentos (COUTURE; CORY, 2009).

\subsection{PROINFA E PERSPECTIVAS FutuRAS}

A potência aprovada no âmbito do Proinfa foi de 3.315,26 MW. Foram contratados 144 projetos que totalizarão 3\% da geração de eletricidade do Sistema Interligado Nacional. Os projetos de biomassa contribuirão com $21 \%$ da energia gerada, os projetos eólicos com $28 \%$, e os projetos de pequenas centrais hidrelétricas (PCHs) com 51\%. (ANEEL, 2009).

Segundo a última atualização de dados do Proinfa feita pelo Ministério de Minas e Energia em 2010, existem 99 usinas em operação (totalizando 2.229,2 MW) e outras 69 usinas não concluídas, que totalizarão 1.056,8 MW.

Dos projetos contratados, 23 são empreendimentos de biomassa, sendo que 21 já entraram em operação e 1 está em construção e 1 em projeto. Dos 63 projetos de PCHs, 48 encontram-se concluídos e 11 estão em construção e 4 em projeto. Os projetos eólicos somam 56 parques os quais 30 em operação comercial, 9 em construção, e 17 em fase de projeto. Do total de projetos, 22 ainda não tiveram sua construção iniciada (ANEEL, 2010), 7 deles estão com o contrato de EPC assinados e os outros nove não devem se concretizar: Além disso, quatro usinas de biomassa foram descontratadas e duas PCHs estão embargadas por decisões judiciais.

Tabela 7.4.1 - Resultados Parciais do Proinfa

\begin{tabular}{|l|c|c|c|c|c|c|c|c|c|c|c|}
\hline \multirow{2}{*}{ Fonte } & \multicolumn{3}{|c}{$\begin{array}{c}\text { Em } \\
\text { operação }\end{array}$} & \multicolumn{4}{c|}{$\begin{array}{c}\text { Em } \\
\text { construção }\end{array}$} & \multicolumn{3}{c|}{$\begin{array}{c}\text { Sem } \\
\text { construção }\end{array}$} & \multicolumn{3}{c|}{ TOTAL } \\
\cline { 2 - 13 } & Qtd & MW & $\%$ & Qtd & MW & $\%$ & Qtd & MW & $\%$ & Qtd & MW \\
\hline PCH & 48 & 984,3 & 83 & 11 & 156,2 & 13 & 4 & 47,4 & 4 & $\mathbf{6 3}$ & $\mathbf{1 . 1 8 7 , 9}$ \\
\hline Biomassa & 21 & 563,2 & 85 & 1 & 70,4 & 11 & 1 & 32 & 5 & $\mathbf{2 3}$ & $\mathbf{6 6 5 , 6}$ \\
\hline Eólica & 30 & 681,7 & 48 & 9 & 154,4 & 11 & 17 & 596,4 & 42 & $\mathbf{5 6}$ & $\mathbf{1 . 4 3 2 , 5}$ \\
\hline TOTAL & $\mathbf{9 9}$ & $\mathbf{2 . 2 2 9 , 2}$ & $\mathbf{6 5}$ & $\mathbf{2 1}$ & $\mathbf{3 8 1 , 0}$ & $\mathbf{1 1}$ & $\mathbf{2 2}$ & $\mathbf{6 7 5 , 8}$ & $\mathbf{2 0}$ & $\mathbf{1 4 2}$ & $\mathbf{3 . 2 8 6}$ \\
\hline
\end{tabular}

Fonte: Proinfa, ELETROBRÁS, 2010 
O Proinfa deveria ter terminado ao final de 2008, mas a Eletrobrás aceitou a justificativa de caso fortuito ou força maior para alguns dos projetos atrasados e o prazo para implantação de projetos foi extendido para dezembro de 2010.

A despeito do grande potencial energético de 143 mil MW estimados no Atlas do Potencial Eólico Brasileiro (AMARANTE; BROWER; ZACK, 2001), o setor eólico apresentou fragilidade em sua estrutura industrial no curto prazo. Conseqüentemente, os principais problemas no Proinfa se concentraram nos projetos de geração eólica. O monopólio na produção de aero geradores por apenas poucas empresas no país eleva os custos dos componentes e conseqüentemente da energia eólica. Esta realidade mudou significativamente com os sucessivos leilões de energia eólica que atraíram a participação de novas empresas no mercado, garantindo o início do desenvolvimento de uma cadeia de suprimentos de equipamentos, componentes e infra-estrutura mais madura.

Por enquanto, cerca de 600 MW de eólicas do Proinfa não começaram a ser construídas e, portanto, não tem previsão de entrada em operação.

Os projetos de PCHs não apresentaram gargalos tecnológicos. O Brasil é líder mundial no setor com $2850 \mathrm{MW}$ instalados, distribuídos em 345 empreendimentos em operação (ANEEL, 2009). Segundo o MME, as PCHs encontram-se dentro do prazo previsto no Proinfa e totalizarão 1.191,2 MW de capacidade instalada distribuídos em 63 empreendimentos (MME, 2010).

Em relação às $\mathrm{PCHs}$, está prevista para os próximos anos um acréscimo de 877,3 MW na capacidade de geração, por meio de 64 empreendimentos em construção. As usinas outorgadas entre 1998 e 2010 devem gerar 2.073 MW de potência. Entretanto, as $\mathrm{PCHs}$ tem perdido competitividade em relação às demais renováveis, por conta de mudanças no marco regulatório de registro e outorga de PCHs (Resolução 343/2008), alterações de exigências da Aneel, relacionadas ao projeto básico das usinas e falta de incentivos de desoneração fiscal sobre equipamentos, como a presente para projetos eólicos.

Para a fonte biomassa, foram identificados problemas de conexão de usinas à rede básica (três projetos solicitaram rescisão) e no suprimento de equipamentos nacionais. A licitação da construção de linhas de transmissão e subestações coletoras pela EPE foi fundamental para compensar a falta de investimento das distribuidoras na ampliação das linhas de transmissão afetando tanto as usinas a biomassa, quanto os projetos de parques eólicos. 
Mais da metade das usinas sucroalcooleiras que contrataram energia no leilão de reserva de 2008 da Aneel estão com a entrega de 2010 atrasada, por conta de problemas nas próprias obras ou que aguardam pela conclusão das linhas de transmissão e distribuição. Apesar disto, a projeção de crescimento do setor é mantida; 55 projetos de usinas estão cadastrados a participar do leilão de reserva, número superior de projetos em relação ao leilão de 2008. A Única (União da Indústria de Cana-de-açúcar) espera que a energia cogerada a partir do bagaço de cana salte dos 5.869 GWh em 2009 para 9.198 GWh até o fim de 2010.

Tanto a capacidade adicionada pelo Proinfa até o fim de 2010 como a energia comercializada nos leilões deverão ser integradas ao sistema interligado nacional. Há previsão de geração adicional de aproximadamente 1500 MW de cogeração a bagaço de cana (542 MW comercializadas no leilão de energias renováveis de 2007 e outros 1096 no leilão específico para biomassa, em 2008) e 1053 MW de PCHs. O leilão de energia eólica negociou $1805 \mathrm{MW}$ em parques eólicos, que deverão entrar em operação até 2012. Os investimentos previstos para a construção dos parques são de 9,4 bilhões de reais, ou pouco mais de 5 bilhões de dólares.

As concessionárias foram responsáveis pela expansão da geração solar fotovoltaica em sistemas isolados no âmbito do programa de universalização. A COELBA (Companhia de Eletricidade da Bahia) irá implementar painéis fotovoltaicos para mais de 80 mil consumidores em comunidades isoladas como alternativa econômica à expansão da rede elétrica. Para sistemas conectados à rede, o MME estabeleceu o Grupo de Trabalho de Geração Distribuída com Sistemas Fotovoltaicos, GT-GDS em 2008, através da Portaria n³6, da Secretaria de Desenvolvimento e Planejamento Energético. $O$ objetivo da ação é o desenvolvimento de estudos e propostas de políticas de utilização de geração fotovoltaica conectada à rede para edificações urbanas. O MME pretende estabelecer uma política de estímulo à energia fotovoltaica com incentivo à instalação de painéis visando o aumento da produção e o refino do silício, matéria prima fundamental sua fabricação. 


\subsection{LeILÕes de RENOVÁveIs e PERSPectivas Futuras}

Além do Proinfa, figuram entre iniciativas pontuais de ampliação da capacidade instalada de energias renováveis o primeiro leilão ${ }^{14}$ de fontes alternativas e o primeiro leilão de reserva. As três iniciativas diferenciam-se pelos seus objetivos. O Proinfa teve como objetivo único a inserção das fontes renováveis alternativas no mercado. O Primeiro Leilão de Fontes Alternativas teve como objetivo principal o atendimento da demanda das distribuidoras. Já o Primeiro Leilão de Reserva teve como objetivo a segurança de abastecimento, privilegiada pela contratação de energia proveniente de biomassa como fonte geradora (MARTINS; CAVALIERO, 2009).

\subsubsection{Primeiro Leilão de Fontes Alternativas}

O primeiro Leilão de Fontes Alternativas foi realizado no dia 18 de junho de 2007 pela ANEEL, com o objetivo de atender a demanda das distribuidoras e promover a contratação de energia elétrica proveniente de Fontes Alternativas de Geração, implantadas no SIN, no ambiente de contratação regulada ${ }^{15}$, a partir de 10 de janeiro de 2010.

O edital definiu as regras para a participação do certame e estipulou o preço teto de $R \$ 135,00 / M W h$ para hidrelétricas e $R \$ 140,00 / M W h$ para as demais fontes. Os empreendimentos foram avaliados pelo Índice de Custo Beneficio $-I^{I C B}{ }^{16} \mathrm{e}$ classificados em ordem crescente.

\footnotetext{
${ }^{14}$ O leilão é um sistema competitivo de venda de energia pelos produtores a partir da determinação pelo governo da quantidade de energia produzida e preço pago pela mesma. A proporção entre os riscos e os lucros torna o leilão pouco atrativo para os investidores.

${ }^{15} \mathrm{O}$ novo Modelo do setor elétrico define que a comercialização de energia elétrica é realizada em dois ambientes de mercado, o Ambiente de Contratação Regulada - ACR e o Ambiente de Contratação Livre - ACL. A contratação no ACR é formalizada através de contratos bilaterais regulados, entre Agentes Vendedores e distribuidores que participam dos leilões. Já no ACL há a livre negociação entre os Agentes Geradores, Comercializadores, Consumidores Livres, Importadores e Exportadores de energia, por meio de contratos bilaterais (CCEE, 2009)

${ }^{16}$ Índice de Custo-Benefício, metodologia utilizada para a ordenação econômica de empreendimentos termelétricos, ordenados em ordem decrescente. É definido como a razão entre o seu custo total e o seu benefício energético.
} 
Sistemas de leilões semelhantes foram aplicados, sem sucesso, para promover a energia eólica em países como Irlanda, França, Dinamarca e Reino Unido. No caso do Reino Unido, o sistema de Non-Fossil-Fuel Obligation ou Obrigação de Combustíveis Não-Fósseis vigorou entre 90 e 98 . O sistema ficou comprometido ao não prever uma penalidade para o descumprimento do prazo de entrega e será substituído por um sistema feed in a partir de 2010.

Em algumas políticas, o sistema competitivo é usado para empreendimentos de grande porte, e o esquema feed in empregado para projetos de pequena escala. Esta proposta é empregada em estados norte-americanos como Califórnia e Washington (COUTURE; CORY, 2009) e também foi sugerida recentemente no Brasil, pela Comissão Especial de Energias Renováveis.

Um total de 70 empreendimentos foi habilitado para o leilão de energia alternativa, somando uma potência instalada de $2.022 \mathrm{MW}$. As pequenas centrais hidrelétricas representaram $70 \%$ do total, com $751 \mathrm{MW}$ de capacidade de geração, as térmicas de biomassa totalizam 15 habilitações, com potência de 649 MW, além de seis usinas eólicas, com 622 MW (CCEE, 2009).

Neste leilão foram negociados $186 \mathrm{MW}$ médios: 6 empreendimentos hidroelétricos totalizando $46 \mathrm{MW}$ médios e 12 de biomassa totalizando $140 \mathrm{MW}$ médios. As usinas eólicas não participaram do processo.

A razão pela negociação de um volume tão inferior ao inicialmente habilitado foi o preço médio praticado ( $\mathrm{R} \$ 137,32$ por $\mathrm{MWh}$ ), considerado baixo tanto para as térmicas a biomassa, cujos empreendedores preferiram tentar preços mais altos de venda no mercado livre, tanto para as eólicas, que sequer entraram no leilão.

Outros motivos para a não participação de diversos empreendimentos no leilão foram a falta de documentação necessária para habilitação e a falta de acesso de outras usinas às linhas de transmissão, desconectadas às distribuidoras de eletricidade. Em síntese, a maior parte dos problemas identificados foi similar aos do Proinfa.

O Ministério de Minas e Energia reconheceu que a energia eólica merece um tratamento diferenciado, como o aumento do preço e do prazo de contratação, melhores condições de financiamento e a contratação de energia por quantidade, procedimento aplicado para as termelétricas neste mesmo leilão ${ }^{17}$.

\footnotetext{
${ }^{17}$ Neste tipo de contrato os geradores recebem pela quantidade de energia firme (assegurada, fixa) e não pela quantidade de energia que foi realmente gerada.
} 


\subsubsection{Primeiro Leilão de Reserva}

O primeiro Leilão de Reserva foi realizado no dia 14 de agosto de 2008 com o objetivo de contratação de energia elétrica de reserva, proveniente de biomassa, para a entrada em operação nos anos de 2009 e 2010. O Leilão de Reserva foi estabelecido com a finalidade de manter a segurança de abastecimento no país. $O$ preço inicial para o leilão foi de $\mathrm{R} \$ 157,00 / \mathrm{MWh}$.

Os empreendimentos selecionados geram energia durante a safra ${ }^{18}$, vendendo-a no mercado de curto prazo. A primeira habilitação teve 118 interessados, num total de 7,8 mil MW. Destes, apenas 44 aceitaram as condições oferecidas pelo governo e participaram do leilão. No final, foram negociados 859 MWmédios; o volume ficou abaixo das expectativas de contratação, que visavam atender o déficit de demanda energética de 1.000 MWmédios previsto para 2009, ano seguinte ao leilão (CCEE, 2009).

Uma das principais divergências foram os custos de conexão, dependentes da localização do projeto e da configuração geográfica da rede de transmissão existente, e que seriam arcados pelos geradores. O preço inicial para o leilão, de $\mathrm{R} \$ 157,00 / \mathrm{MWh}$, também não foi considerado atrativo por todos os produtores. Houve uma expressiva elevação dos custos de investimento e operação da cogeração de energia, entre 2007 e $2008^{19}$. Mais de $60 \%$ da biomassa ainda se encontra em regiões tradicionais de cana, onde predominam usinas antigas, dependentes de grandes reformas e investimentos, resultando em um maior custo para a eletricidade produzida.

A partir dos resultados dos mecanismos nacionais de implantação de geração elétrica renovável, conclui-se que estes deixaram a desejar em relação à quantidade de capacidade instalada ao sistema elétrico nacional. Os leilões têm decepcionado as expectativas de contratação de usinas. O Proinfa deve atingir uma meta próxima à inicialmente proposta, possibilitada pela correção de parâmetros do programa durante seu curso e com o ônus do atraso na construção de boa parte dos empreendimentos.

\footnotetext{
${ }^{18}$ Entre os meses de maio e novembro. Nos demais meses, os produtores ficam desobrigados de adquirir energia no mercado de curto prazo.

${ }_{19}$ Destacam-se a alta dos preços da terra, dos principais insumos agrícolas, da mão-de-obra e do aço para máquinas e equipamentos das centrais de co-geração.
} 
Se o critério de avaliação for a tendência de queda de preço das tecnologias, aponta-se que o sistema de leilões conseguiu este resultado para PCHs e para eólicas, cujos preços atuais mostram-se notoriamente inferiores aos oferecidos no Proinfa. Entretanto, esta queda de preço não se reverteu em maiores investimentos em capacidade instalada para o caso da biomassa.

\subsubsection{Segundo Leilão de Reserva - Primeiro Leilão de Energia Eólica}

O segundo Leilão de Reserva foi realizado no dia 14 de dezembro de 2009, novamente com o objetivo de contratação de energia elétrica de reserva, desta vez proveniente exclusivamente de fonte eólica, para a entrada em operação no ano de 2012. A motivação principal da realização deste leilão foi a garantia da segurança de abastecimento nacional, justificada pelo Ministério de Minas e Energia pela dificuldade e atraso na obtenção de licenciamento da hidrelétrica de Belo Monte (11.233 MW). O preço inicial para o leilão foi de $\mathrm{R} \$ 189,00 / \mathrm{MWh}$.

O leilão de energia eólica teve a inscrição de $13.341 \mathrm{MW}$ de empreendimentos e a habilitação de 10.005 MW em 339 projetos. O preço teto de $\mathrm{R} \$ 189,00 / \mathrm{MWh}$ provocou a desistência de cerca de $4000 \mathrm{MW}$ em projetos no início do certame. No final foram negociados $1805 \mathrm{MW}$ (ou $753 \mathrm{MW}$ médios) em 71 empreendimentos.

O preço final foi de $\mathrm{R} \$ 148,39 / \mathrm{MWh}$, uma redução de $21,5 \%$ em relação ao teto de R\$189/MWh. O valor foi considerado economicamente viável por uma parcela dos empreendimentos, mas afastou a maioria dos projetos que participaram do leilão. O valor foi atribuído a uma conjunção de fatores financeiros e técnicos. Dentre os fatores financeiros estavam a desoneração tributária dos projetos, as boas condições de financiamento, a desvalorização do dólar, e a concessão de créditos de carbono aos empreendedores. Os fatores técnicos mais relevantes foram a localização privilegiada de projetos em relação à logística de construção e proximidade de linhas de transmissão, e os elevados fatores de capacidade dos sítios.

O pagamento da receita dos aerogeradores seguiu uma sistemática diferente do feed-in por uma demanda dos empreendedores, que pediram por previsibilidade 
de receita e fluxo de caixa. Criou-se um sistema de bandas que simula um reservatório de energia eólica similar a um hidrelétrico, que garante a receita desde que não forem ultrapassados limites inferiores $(-10 \%)$ e superiores $(+30 \%)$ de geração, aplicando penalidades nestes $\operatorname{casos}^{20}$. Neste leilão as usinas eólicas foram contratadas na modalidade de energia de reserva e os contratos liquidados na Câmara de Comercialização de Energia Elétrica.

O Ministério de Minas e Energia declarou na época que a competitividade das eólicas sinalizou que estas poderiam participar dos próximos leilões regulares, competindo com empreendimentos nas demais fontes energéticas. Esta realidade será possível desde que sejam mantidas as renúncias fiscais, sobre impostos de importação, circulação de mercadorias e serviços, entre outros. Esta intenção não é definitiva; às vésperas do leilão, o Conselho Nacional de Política Fazendária restringiu a prorrogação do ICMS - Imposto de Circulação sobre Mercadorias e Serviços, impactando a rentabilidade de diversos projetos.

\subsubsection{Leilão de Fontes Alternativas (A-3) e Terceiro Leilão de Reserva - Fontes Renováveis}

No final de agosto de 2010 foram realizados dois leilões para fontes alternativas de energia. Foram eles o leilão A-3 (25/8) e o terceiro leilão de reserva (26/8) estabelecido pelo decreto 645 de julho de 2010, para as fontes $\mathrm{PCH}$, biomassa e eólica.

Previamente a realização dos leilões a Empresa de Pesquisa Energética (EPE), havia divulgado a inscrição de 517 projetos de empreendimentos que somam 15.774 megawatts (MW) de capacidade instalada. Deste total as PCHs participam com apenas 18 projetos totalizando 255 MW. Segundo a Associação Brasileira dos Pequenos e Médios Produtores de Energia Elétrica (APMPE) as PCHs enfrentam perda de competitividade frente a outras fontes de energias por não contar com os mesmos benefícios de desoneração tributária como a isenção de $100 \%$ do ICMS

\footnotetext{
${ }^{20}$ Em caso de geração superior a 30\% do limite superior, ou o "transbordamento" do reservatório virtual, o gerador recebe $70 \%$ do valor do contrato. No caso contrário, se a geração for $15 \%$ inferior ao limite mínimo, ou no caso de "seca" do reservatório virtual, o gerador paga $15 \%$ do preço contratado. Desta forma é criado o reservatório da energia eólica.
} 
oferecido para eólica ou condições de financiamento privilegiada oferecidas para a Usina de Belo Monte (11.233MW) - como $75 \%$ de isenção de imposto de renda por 10 anos e financiamento de 30 anos com taxa de juros de 4\%. A APMPE acredita que com os mesmos benefícios poderiam reduzir seu preço de $R \$ 160 / \mathrm{MWh}$ para $\mathrm{R} \$ 145 / \mathrm{MWh}$.

Foram inscritos 425 projetos de eólica com capacidade de $11.214 \mathrm{MW}$ e 68 projetos de biomassa, com bagaço de cana e capim elefante totalizando 4.170 MW. Segundo a União da Indústria de Cana de Açúcar (UNICA) a adesão ao leilão de 2010 foi $50 \%$ maior do que no leilão de 2008 . Mais da metade dos projetos contratados neste período e com prazo de entrega para 2010 estão atrasados e o principal motivo foi a falta de crédito no mercado motivado pela crise financeira de 2008-2009. A ANEEL indica que o atraso não afeta apenas as usinas, mas também as obras nas linhas de transmissão e distribuição para conexão na rede do SIN.

Segundo a EPE 2.892,2 MW de potencia instalada (1.159,4 MW médios) forma contratados no leilão. Foram contratadas 70 centrais eólicas, 12 centrais a biomassa e 7 PCHs. O preço médio para a eólica foi de $R \$ 130,86$ por $\mathrm{MWh}$, para biomassa de $R \$ 144,20$ por MWh, e para as $\mathrm{PCHs}$ de $\mathrm{R} \$ 141,93$ por $\mathrm{MWh}$. Os preços finais foram considerados baixos e portanto frustraram a possibilidade de comercialização de um volume maior de energia. Parte da explicação para o baixo valor obtido no caso da energia eólica está relacionado ao aumento da disponibilidade de equipamento no mercado internacional em função da crise econômica européia e americana e aos altos fatores de capacidade nos parques contratados. A APMPE declarou preocupação com a entrega da energia contratada por preços tão reduzidos, já a EPE declarou que o baixo valor da energia eólica significa a quebra de um paradigma.

\subsection{Nova Política Pública de Incentivo a Novas Fontes de Energias RENOVÁVEIS NO BRASIL - PL 630/03}

Atualmente, em paralelo aos leilões de energia, vem sendo proposta uma nova legislação para novas fontes de energias renováveis no Brasil. Este trabalho 
vem acontecendo na Câmara dos Deputados, dentro da Comissão Especial de Energias Renováveis. Esta comissão temporária analisou 19 projetos de lei e produziu o texto para uma nova lei de energias renováveis em julho de 2009.

Os principais pontos do relatório referem-se à proposta de feed-in para turbinas de vento, biomassa ou placas solares conectadas à rede ou em comunidades isoladas, para a geração de pequeno e médio porte conectadas à rede para perfis de geração entre $50 \mathrm{~kW}$ e $1000 \mathrm{~kW}$. Os preços estipulados, de acordo com o artigo 3 do PL 630/03 (GOUVEIA; FERRO, 2009) seguem na tabela 7.6.1 abaixo:

Tabela 7.6.1 - Tarifas Propostas no PL 630/03

\begin{tabular}{|l|c|}
\hline \multicolumn{1}{|c|}{ Fontes/Sistemas } & GD (50 kW até 1.000 $\mathbf{k W})$ \\
\hline $\begin{array}{l}\text { PCH e termelétricas a biomassa de atividades agropecuárias, } \\
\text { florestais e industriais }\end{array}$ & $\mathrm{VR}^{21}+10 \%=\mathrm{R} \$ 142 / \mathrm{MWh}$ \\
\hline Termelétricas a biomassa de resíduos urbanos e esgotos & $\mathrm{VR}+20 \%=\mathrm{R} \$ 155 / \mathrm{MWh}$ \\
\hline Energia Eólica & $\mathrm{VR}+50 \%=\mathrm{R} \$ 194 / \mathrm{MWh}$ \\
\hline Energia geotérmica, maremotriz e das ondas & $\mathrm{VR}+100 \%=\mathrm{R} \$ 258 / \mathrm{MWh}$ \\
\hline
\end{tabular}

Fonte: Substitutivo ao Projeto de Lei 630, de 2003

Para a microgeração de energia (empreendimentos inferiores a $50 \mathrm{~kW}$ ), de acordo com o artigo 5 (GOUVEIA; FERRO, 2009), a remuneração será calculada anualmente e terá como piso a tarifa média nacional de fornecimento ao consumidor residencial, referente aos doze meses anteriores, excluída a Subclasse Residencial Baixa Renda no cálculo da referida tarifa média. Exceção é feita à geração solar, que será remunerada de acordo com o valor de referência acrescido de $450 \%$, ou algo em torno dos $\mathrm{R} \$ 710 / \mathrm{MWh}$.

$\mathrm{Em}$ relação às comunidades isoladas, o artigo 10 estipula que as concessionárias atendam a todo o suprimento de sistemas isolados prioritariamente por meio de fontes renováveis, contratadas por licitação, recebendo a remuneração equivalente ao custo total de geração de energia elétrica (GOUVEIA; FERRO, 2009).

Para a geração de grande porte em parques eólicos, centrais de cogeração e pequenas centrais hidrelétricas, foi prevista no artigo 2 do substitutivo a realização de leilões anuais, oferecendo uma quantidade mínima de 600 MW médios das

\footnotetext{
${ }^{21}$ Valor anual de referência - VR: Valor utilizado para regular o repasse às tarifas dos consumidores finais dos custos de aquisição de energia elétrica, conforme descrito no art. 34 do Decreto $n^{\circ} 5.163$, de 2004.
} 
fontes eólica, biomassa e pequenas centrais hidrelétricas (com 200 MW médios para cada). A regularidade na realização destes leilões pode dar uma visão de longo prazo ao mercado - desde que o preço de referência das energias negociadas no leilão viabilize economicamente as usinas de geração renovável e que a quantidade de energia negociada tenha um volume capaz de estimular o mercado. A quantia mínima de $200 \mathrm{MW}$ médios anuais (equivalente a 500 MW no caso das eólicas) é um bom começo para o Brasil, mas deve ser ampliada com o tempo.

Na proposta está incluída, no artigo 7, a obrigatoriedade de compra anual de 100 MW médios de energias alternativas pelas concessionárias, inspirada no sistema de quotas ou certificados verdes, no qual se define uma meta de participação de energias renováveis no portfólio das empresas de energia.

O texto propõe, nos artigos 3 e 5 , que todo empreendimento renovável de geração distribuída e microgeração (até $1000 \mathrm{~kW}$ ) tenha isenção total de custos de transmissão e distribuição. A medida deve viabilizar uma série de empreendimentos distantes da rede que, em condições anteriores arcariam com os custos de transporte de energia.

Propõe-se, no artigo 32, a dedução de gastos com a aquisição de bens e prestação de serviços referentes a instalações de geração renovável do lucro operacional líquido das empresas responsáveis pelos mesmo. Medidas similares já vêm sendo adotadas nos Estados Unidos, Europa, China e Índia, mas ainda não tem consenso dentro do governo brasileiro. O Ministério do Desenvolvimento, Indústria e Comércio Exterior zerou as taxas de importação de aerogeradores para o leilão, o Ministério da Fazenda garantiu a prorrogação do imposto sobre circulação de mercadorias e serviços para janeiro de 2011.

O texto da comissão também propõe, no artigo 28 , a criação de um fundo para a pesquisa e desenvolvimento de energias renováveis, formado por parte dos lucros da exploração do pré-sal e parte da receita líquida operacional de termelétricas fósseis no artigo 28. O desenvolvimento da pesquisa e inovação tecnológicas é de grande importância principalmente para o desenvolvimento de todas as fontes renováveis no Brasil, especialmente a energia eólica, uma vez que 
cada sítio de ventos exige a confecção de turbinas específicas e adaptadas às condições locais, de forma a aumentar seu rendimento ${ }^{22}$.

\subsection{Propostas Alternativas}

Em relação aos mecanismos vigentes, espera-se, além da capacidade adicionada pelo Proinfa até o fim de 2010, que a energia comercializada nos leilões também integre o sistema interligado nacional. Está prevista a geração adicional de aproximadamente 1000 MW médios de cogeração a bagaço de cana (entre os volumes comercializados no leilão de energias renováveis e no leilão específico para biomassa, em 2008) e 1053 MW de PCHs. A capacidade instalada em 2009 até julho foi de 565,4 MW, de uma capacidade instalada total de 1,61 mil MW (MAGOSSI; BAHNEMANN, 2009).

A Associação das Indústrias de Açúcar e Álcool (AIAA) anunciou que o setor pretende investir 4 bilhões de reais em cogeração a biomassa, em 42 projetos que devem somar 2.500MW em capacidade instalada até 2015. Os cronogramas estavam previstos para 2012, mas o financiamento foi atrasado por conta da crise financeira.

A energia eólica deve ampliar sua capacidade instalada em 1805 MW, em decorrência da energia contratada no leilão de eólicas. Os investimentos previstos para a construção dos parques são de 9,4 bilhões de reais, ou pouco mais de 5 bilhões de dólares.

Apesar da presença das PCHs no leilão de fontes alternativas, estas usinas tem trilhado um caminho paralelo às demais formas de geração que receberam leilões exclusivos de energia. Os empreendimentos que não estão incluídos no Proinfa são autorizados por chamada pública pela Agência Nacional de Energia Elétrica (ANEEL). São exigidos pagamentos e garantias bancárias aos empreendedores, de forma a assegurar o cumprimento dos prazos de construção. Acreditava-se que a ANEEL iria liberar cerca de 6.500 MW de potência em PCHs, considerando o número de investidores interessados no leilão de 2008. Associação de Pequenos e Médios Produtores de Energia APMPE, pedia a realização de um

\footnotetext{
${ }^{22}$ No RN, turbinas funcionam com geradores cujo fator de capacidade pouco acima de $30 \%$, quando o potencial local permitiria um aproveitamento superior a $40 \%$ e um ganho de receita consideravelmente superior.
} 
leilão exclusivo para a fonte, a fim de ampliar a implantação de usinas (LEAL, 2009), entretanto foi decretado um leilão para PCHs, biomassa e eólica previsto para agosto de 2010.

Há outras propostas alternativas aos mecanismos feed in ou de leilões. Uma delas é a extensão às fontes renováveis da metodologia de calculo de ICBs (EPE, 2006) e custo variável de operação ${ }^{23}$ empregada em térmicas participantes de leilões. Somando-se a redução dos custos operativos das térmicas e a redução dos níveis de emissões, a inserção de 4000 MW médios de energia eólica até 2020 não provocaria incremento de custo e reduziria o preço de liquidação de diferenças $(P L D)^{24}$ em R\$15,00/MWh (VEIGA, 2009).

Outra proposta, de autoria da Associação Brasileira de Energia Eólica (Abeeólica) é de estímulos fiscais para as obras eólicas, similares às medidas fiscais aplicadas internacionalmente. A carga tributária representa uma parcela entre 25,7\% e $30,2 \%$ do gasto total para a construção de um parque eólico. A associação propõe incentivos via PIS/COFINS, IPI, ICMS e ISSQN para bens de capital de toda a cadeia produtiva. Parte destas isenções foi aplicada aos empreendimentos concorrentes do leilão de energia eólica, resultando na redução do preço final da energia eólica nos últimos leilões A-3 e de Reserva. O prolongamento da isenção total deste conjunto de impostos aumentaria as possibilidades de contratação destas energias, em outros leilões, de acordo com a posição do Ministério de Minas e Energia em defender a participação dos empreendimentos renováveis em certames comuns como o A-3 e A-5, à medida em que ganhem competitividade.

A proposta tem inspiração em diferentes medidas de redução no custo final da energia por incentivos fiscais ${ }^{25}$, como os créditos de impostos ou Production Tax Credits (PTC), utilizados nos EUA e no Canadá desde 1992 (MALLON, 2006).

\footnotetext{
${ }^{23}$ A parcela Custo Variável de Operação - COP (em R \$/ano) é função do nível de inflexibilidade no despacho da usina (por contratos de combustível "take or pay") e do custo variável de O\&M, declarados pelo empreendedor, os quais determinam sua condição de despacho em função também dos custos marginais de operação futuros observados no SIN.

${ }^{24} \mathrm{O}$ preço de liquidação de diferenças (PLD) valoriza a energia comercializada no Mercado de Curto Prazo. É divulgado semanalmente pela Câmara de Comercialização de Energia Elétrica e é calculado com base no Custo Marginal de Operação.

${ }^{25} \mathrm{O}$ sistema fiscal é utilizado no apoio a fontes renováveis em diferentes modalidades de redução ou abatimento em impostos especiais aplicados na geração, isenção tributária para fundos verdes e utilização de fundos específicos para geração limpa. A deficiência do PTC compreende os efeitos dos ciclos de expiração e extensão do programa, que comprimem as demandas por energias renováveis em períodos estreitos de desenvolvimento, ocasionando um baixo desenvolvimento da estrutura de fabricação de componentes. O ARRA (American Recovery and Reinvestment Act) fornece
} 
Por fim, em relação a sistemas fotovoltaicos conectados à rede, foi criado, a partir da Portaria $n^{\circ} 36$, de 28/11/2008, da Secretaria de Desenvolvimento e Planejamento Energético do Ministério de Minas e Energia, o Grupo de Trabalho de Geração Distribuída com Sistemas Fotovoltaicos (GT-GDS). O objetivo do grupo é propor estudos e propostas de políticas de utilização de geração fotovoltaica conectada à rede, em particular em edificações urbanas em curto, médio e longo prazo. Porém, a proposta de política de estímulo à energia fotovoltaica ainda não foi apresentada até o momento. 


\section{CAPÍTULO 8 - ESTUDO DE VIABILIDADE ECONÔMICA DAS NFER COM ANÁLISE DE PREÇO POR TECNOLOGIA}

\subsection{INTRODUÇÃO}

Este capítulo apresenta uma análise econômica de distintas fontes renováveis em condições variadas de mercado como taxa de retorno, custo de transmissão, crédito de carbono entre outros. Algumas destas condições, como a isenção dos custos de transmissão e o direito à comercialização de créditos de carbono são contempladas na proposta do PL 630/03.

Desta forma, o resultado destes ensaios de condições de formação de preço final por tecnologia pode ser comparado aos valores oferecidos nos programas de contratação de energias renováveis discutidos anteriormente, a fim de se aferir o potencial de desenvolvimento das NFER.

\subsection{PREMISSAS ADOTADAS PARA ESTUdo DE VIABILIDADE ECONÔMICA}

Para estudar a viabilidade econômica de uma comercializadora de energia renovável é preciso definir a margem ideal de preço de tarifa para cada tecnologia. $\mathrm{A}$ simulação permite verificar a margem ideal de preço de tarifa para cada tecnologia frente ao preço pago por consumidores corporativos ou residenciais. As tecnologias analisadas são as três fontes contempladas no Proinfa: energia eólica, pequena central hidrelétrica e cogeração da biomassa com bagaço de cana. Os projetos foram avaliados com premissas comuns.

- Plantas de 30MW de capacidade instalada

- Variação com taxa de retorno de $15 \%, 17,5 \%$ e $20 \%$

- Financiamento com $65 \%$ via BNDES com taxa de $9,25 \%$ ao ano e $35 \%$ no mercado a $12 \%$ ao ano.

- Os valores foram corrigidos no tempo pela taxa do IGPM 
- O custo da taxa de transmissão ( $\mathrm{R} \$ \mathrm{kWh}$ por mês) sofreu variação de $100 \%, 50 \%$ e $0 \%$.

- A análise incluiu o efeito da remuneração pelo crédito de carbono valorado a 8 euros por tonelada de $\mathrm{CO} 2$. (com taxa de conversão de $\mathrm{R} \$ 2,30$ por euro).

- O fator de capacidade adotado para eólica foi de $42 \%$ (típico da região nordeste), para $\mathrm{PCH}$ e biomassa de $60 \%$ (padrão na região sudeste).

- O custo de operação e manutenção em $R \$ / M W h$ para $P C H s$ foi estimado em $R \$ 12$, para a eólica em $R \$ 25$ e para biomassa que é mais intensiva no uso de mão de obra $\mathrm{R} \$ 50$.

- A taxa de inflação adotada foi de $4 \%$

- A taxa de seguro de $0,5 \%$ do investimento total

- Foi feita uma variação de acréscimo e decréscimo de $10 \%$ do valor do investimento para simular a variação do câmbio ou o impacto de ampliação ou redução do custo inicial do projeto durante sua implementação.

\subsection{RESULTADOS PARA ENERGIA EÓLICA}

Os resultados da simulação para eólica apontaram uma variação de $34 \%$ entre o menor e maior valor obtido. O menor resultado foi $\mathrm{R} \$ 143,35 / \mathrm{MWh}$ com uma taxa de retorno de $15,0 \%, 100 \%$ de desconto na tarifa fio e crédito de carbono. Se considerada uma taxa de $10 \%$ de deságio o valor cairia para $\mathrm{R} \$ 136.69 / \mathrm{MWh}$. O maior preço obtido foi de $\mathrm{R} \$ 174,47 / \mathrm{MWh}$ com $20 \%$ de taxa de retorno, sem desconto de tarifa fio e sem crédito de carbono. Os resultados com $15 \%$ de taxa de retorno não representam atuais condições de mercado e são apenas possíveis em função da política agressiva do governo nos financiamentos, em particular destaque para o Banco do Nordeste. No caso da eólica o câmbio tem uma forte influência sobre o resultado, porque praticamente $70 \%$ do investimento é precificado no mercado internacional. $\mathrm{Na}$ análise feita com $10 \%$ de acréscimo ao investimento (equivalente a uma variação no câmbio do euro) podemos notar que o preço da energia sobe para $\mathrm{R} \$ 183,09 / \mathrm{MWh}$. Através desta análise podemos verificar que no 
atual sistema, o preço teto de $\mathrm{R} \$ 167,00 / \mathrm{MWh}$ estabelecido para o leilão de energia eólica em agosto de 2010 foi pouco maior que os $\mathrm{R} \$ 164,38 / \mathrm{MWh}$, que o empreendedor conseguiria com uma taxa de retorno de $17,5 \%$ sem acesso aos créditos de carbono, ou desconto total da tarifa fio. A simulação apresentada indica que para se obter o valor médio de $\mathrm{R} \$ 130,86$ para eólica no leilão de Agosto de 2010 seria necessário trabalhar com uma condição ideal de deságio dos equipamentos, taxa de retorno de $15 \%$ e fator de capacidade maior que $42 \%$. Os projetos eólicos contam atualmente com desoneração tributária dos projetos, boas condições de financiamento, desvalorização do Dólar/Euro. O Banco do Nordeste ofereceu uma linha de financiamento com taxa de juros de 10\% a.a, participação em até $90 \%$ e prazo de carência de até 20 anos.

A Tabela 8.3.1 apresenta a variação do preço para a energia eólica em $\mathrm{R} \$ / M W h$ para os distintos cenários de simulação. A Figura 8.3.1 apresenta a curva comparativa de preço da energia eólica em $\mathrm{R} \$ / \mathrm{MWh}$ para os distintas taxas de retorno consideradas nesta simulação (15\%, 17,5\% e $20 \%)$.

Tabela 8.3.1 - Resultados da simulação para Energia Eólica em $R \$ / M W h$ para os Distintos Cenários Simulados

\begin{tabular}{|c|c|c|c|c|c|c|}
\hline \multicolumn{7}{|c|}{ Projeto Eólica } \\
\hline $\begin{array}{c}\text { Retorno } \\
\text { Exigido }\end{array}$ & $\begin{array}{c}\mathbf{( - 1 0 \% )} \\
\text { Investimento }\end{array}$ & TUSD (0\%) & $\begin{array}{c}\text { TUSD } \\
(\mathbf{1 0 0 \% )}\end{array}$ & $\begin{array}{c}\text { Preço com } \\
\text { CO2 }\end{array}$ & Preço & $\begin{array}{c}\text { (+10\%) } \\
\text { Investimento }\end{array}$ \\
\hline $20,0 \%$ & $\mathrm{R} \$ 154,83$ & $\mathrm{R} \$ 163,49$ & $\mathrm{R} \$ 165,47$ & $\mathrm{R} \$ 168,94$ & $\mathrm{R} \$ 174,47$ & $\mathrm{R} \$ 183,09$ \\
\hline $17,5 \%$ & $\mathrm{R} \$ 145,79$ & $\mathrm{R} \$ 153,46$ & $\mathrm{R} \$ 155,52$ & $\mathrm{R} \$ 158,92$ & $\mathrm{R} \$ 164,38$ & $\mathrm{R} \$ 172,04$ \\
\hline $15,0 \%$ & $\mathrm{R} \$ 136,69$ & $\mathrm{R} \$ 143,35$ & $\mathrm{R} \$ 145,48$ & $\mathrm{R} \$ 148,81$ & $\mathrm{R} \$ 154,27$ & $\mathrm{R} \$ 160,91$ \\
\hline
\end{tabular}




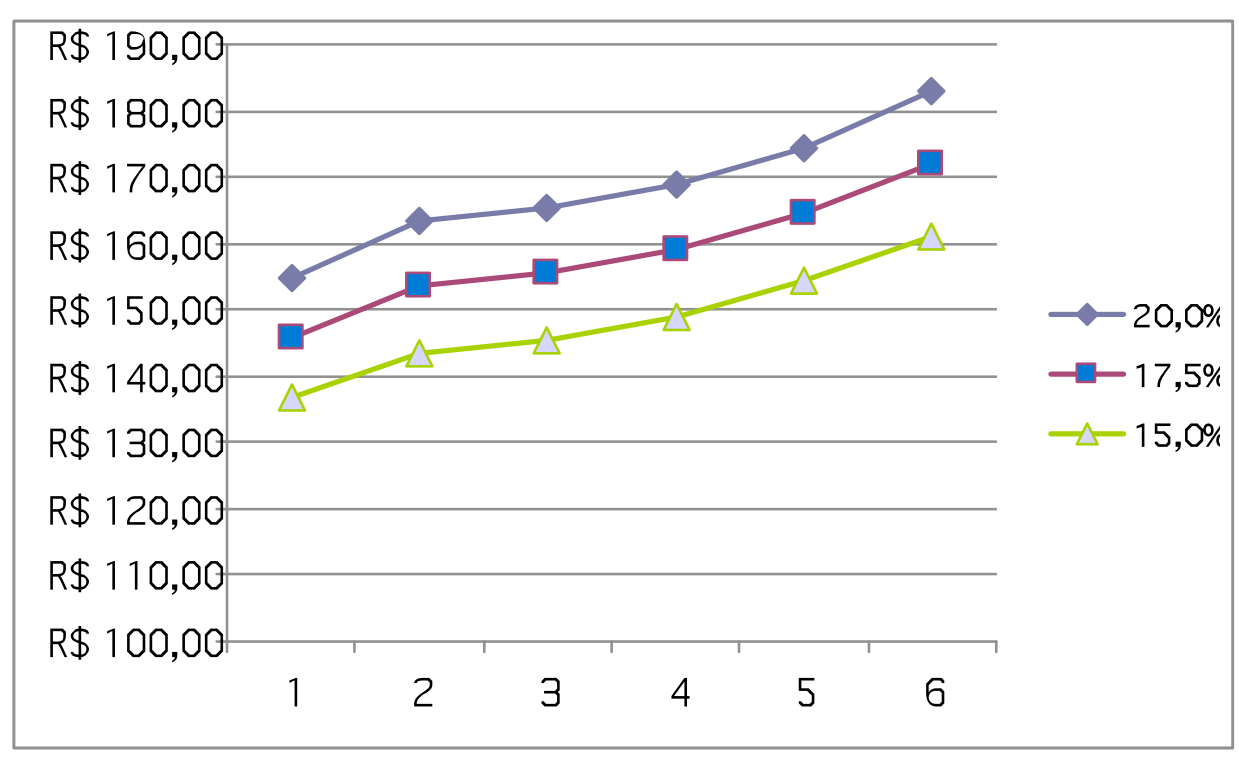

Figura 8.3.1 - Curva Comparativa de Preço da Energia Eólica em R\$/MWh para os Distintos Cenários Simulados

\subsection{RESUltados PARA ENERGIA HídRICA DE PCHS}

Os resultados da simulação para $\mathrm{PCHs}$ apontaram uma variação de $25 \%$ entre o menor e maior valor obtido. O menor resultado foi $\mathrm{R} \$ 128,35 / \mathrm{MWh}$ com uma taxa de retorno de $15,0 \%, 100 \%$ de desconto na tarifa fio e crédito de carbono. Se considerada uma taxa de $10 \%$ de deságio o valor cairia para $\mathrm{R} \$ 123.63 / \mathrm{MW}$. O maior preço obtido foi de $\mathrm{R} \$ 161,04 / \mathrm{MWh}$ com $20 \%$ de taxa de retorno, sem desconto de tarifa fio e sem crédito de carbono. Os resultados com 15\% de taxa de retorno não representam atuais condições de mercado e são apenas possíveis se forem aplicadas para $\mathrm{PCHs}$ a mesma política agressiva do governo nos financiamentos para eólica, em particular destaque para as condições oferecidas pelo Banco do Nordeste. Nesta simulação é possível perceber a importância do efeito tarifa fio (TUSD) conforme discutido no capítulo 3.3. Através desta análise podemos verificar que no atual sistema de leilão o preço teto estabelecido no leilão de energia de PCHs em Agosto de 2010 de $\mathrm{R} \$ 155,00 / \mathrm{MWh}$ foi pouco maior que os $\mathrm{R} \$ 150,87 / \mathrm{MWh}$ que o empreendedor conseguiria com uma taxa de retorno de $17,5 \%$ e sem acesso aos créditos de carbono, ou desconto total da tarifa fio. A simulação apresentada indica que para se obter o valor médio de $R \$ 141,93 / \mathrm{MWh}$ para $\mathrm{PCHs}$ como no leilão de Agosto de 2010 seria necessário trabalhar com uma 
taxa de retorno de $15 \%$ sem isenção de tarifa fio ou crédito de carbono, o que resultaria no valor de $\mathrm{R} \$ 140,63 / \mathrm{MWh}$. Os projetos de $\mathrm{PCH}$ não contam atualmente com a mesma desoneração tributária ou com as mesmas boas condições de financiamento disponibilizados para eólica.

$\mathrm{Na} \mathrm{PCH}$ o câmbio tem uma influência menor sobre o resultado pois a maior parte do investimento é precificado no mercado nacional. A Tabela 8.4.1 apresenta a variação do preço para a energia hídrica de $\mathrm{PCH}$ em $\mathrm{R} \$ / \mathrm{MWh}$ para os distintos cenários de simulação. A Figura 8.4.1 apresenta a curva comparativa de preço da energia hídrica de $\mathrm{PCH}$ em $\mathrm{R} \$ / M W h$ para os distintos cenários simulados.

Tabela 8.4.1 Resultados da simulação para Energia de $\mathrm{PCH}$ em $\mathrm{R} \$ / M W h$ para os Distintos Cenários Simulados

\begin{tabular}{|c|c|c|c|c|c|c|}
\hline \multicolumn{7}{|c|}{ Projeto PCH } \\
\hline $\begin{array}{c}\text { Retorno } \\
\text { Exigido }\end{array}$ & $\begin{array}{c}\text { (-10\%) } \\
\text { Investimento }\end{array}$ & TUSD 0\% & TUSD 100\% & $\begin{array}{c}\text { Preço com } \\
\text { CO2 }\end{array}$ & Preço & $\begin{array}{c}\text { (+10\%) } \\
\text { Investimento }\end{array}$ \\
\hline $20,0 \%$ & $\mathrm{R} \$ 142,00$ & $\mathrm{R} \$ 146,70$ & $\mathrm{R} \$ 151,46$ & $\mathrm{R} \$ 157,60$ & $\mathrm{R} \$ 161,04$ & $\mathrm{R} \$ 175,44$ \\
\hline $17,5 \%$ & $\mathrm{R} \$ 132,84$ & $\mathrm{R} \$ 137,57$ & $\mathrm{R} \$ 142,28$ & $\mathrm{R} \$ 147,51$ & $\mathrm{R} \$ 150,87$ & $\mathrm{R} \$ 164,17$ \\
\hline $15,0 \%$ & $\mathrm{R} \$ 123,63$ & $\mathrm{R} \$ 128,35$ & $\mathrm{R} \$ 133,06$ & $\mathrm{R} \$ 137,33$ & $\mathrm{R} \$ 140,63$ & $\mathrm{R} \$ 152,90$ \\
\hline
\end{tabular}

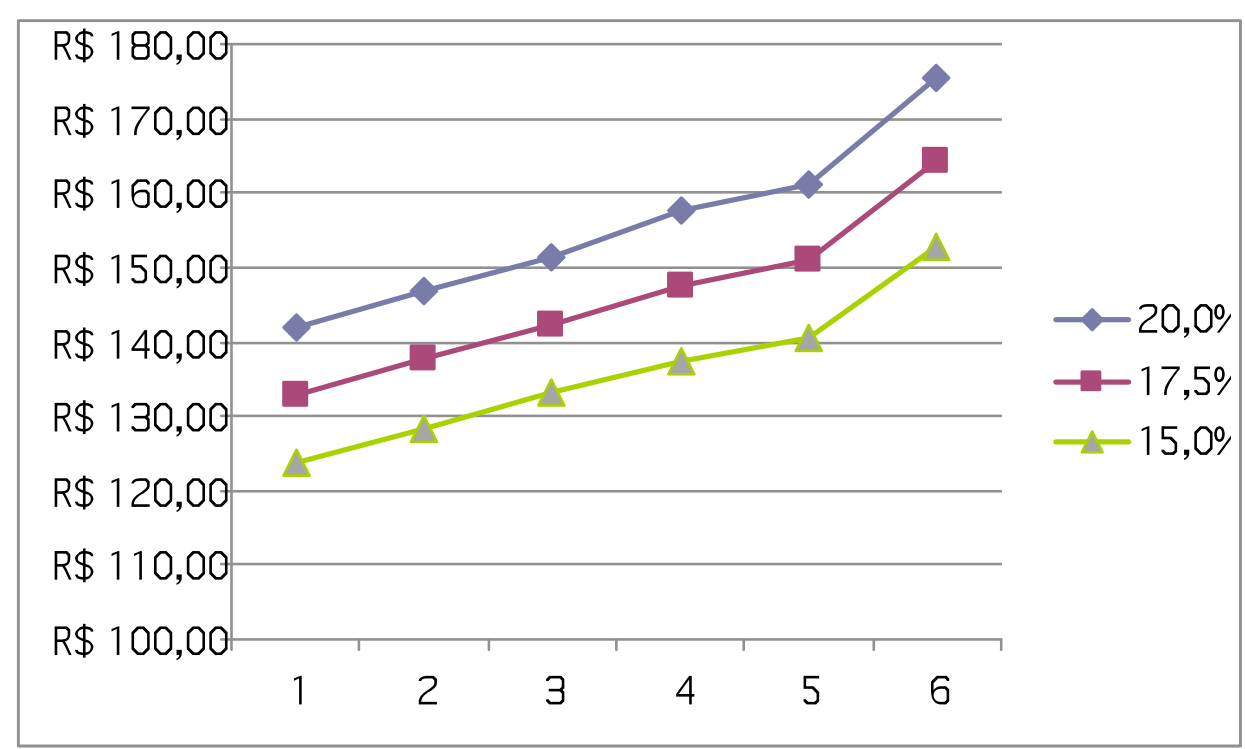

Figura 8.4.1 - Comparação do Preço da Energia de PCH com os Distintos Cenários Simulados 


\subsection{Resultados PARA ENERgIA DE BIOMASSA}

Os resultados da simulação para biomassa apontaram uma variação de 13\% entre o menor e maior valor obtido. O menor resultado foi $R \$ 129,80 / \mathrm{MWh}$ com uma taxa de retorno de $15,0 \%, 100 \%$ de desconto na tarifa fio e crédito de carbono. Se considerada uma taxa de $10 \%$ de deságio, o valor cairia para $\mathrm{R} \$ 126,87 / \mathrm{MWh}$. O maior preço obtido foi de $\mathrm{R} \$ 146,97 / \mathrm{MWh}$ com $20 \%$ de taxa de retorno, sem desconto de tarifa fio e sem crédito de carbono. Os resultados com $15 \%$ de taxa de retorno não representam atuais condições de mercado e são apenas possíveis se forem aplicadas para a biomassa a mesma política agressiva do governo nos financiamentos para eólica, em particular destaque para as condições oferecidas pelo Banco do Nordeste. Através desta análise podemos verificar que no atual sistema, o preço teto de $\mathrm{R} \$ 156,00 / \mathrm{MWh}$ estabelecido para o leilão de energia de biomassa em agosto de 2010 foi pouco maior que os $R \$ 155,71 / \mathrm{MWh}$, que o empreendedor conseguiria com uma taxa de retorno de $20 \%$, sem acesso ao crédito de carbono, desconto total da tarifa fio, e ágio de $10 \%$ como valorização cambial. A simulação apresentada indica que para se obter o valor médio de $R \$ 144,20 / \mathrm{MWh}$ para biomassa como no leilão de Agosto de 2010 seria possível trabalhar com uma taxa de retorno de $17,5 \%$ e sem isenção de tarifa fio ou crédito de carbono o que resultaria no valor de $\mathrm{R} \$ 140,73 / \mathrm{MWh}$. A taxa de $20 \%$ nas mesmas condições resulta no valor de $R \$ 146,97$. A Tabela 8.5.1 apresenta a variação do preço para energia de biomassa em $\mathrm{R} \$ / M W h$ para os distintos cenários de simulação. A figura 8.5.1 apresenta a curva comparativa de preço da energia de biomassa em $\mathrm{R} \$ \mathrm{MWh}$ para os distintos cenários simulados.

Tabela 8.5.1 - Comparação do Preço da Energia de Biomassa com Distintos Cenários de Simulação

\begin{tabular}{|c|c|c|c|c|c|c|}
\hline \multicolumn{7}{|c|}{ Projeto Bagaço } \\
\hline $\begin{array}{c}\text { Retorno } \\
\text { Exigido }\end{array}$ & $\begin{array}{c}(-10 \%) \\
\text { Investimento }\end{array}$ & TUSD (0\%) & $\begin{array}{c}\text { TUSD } \\
(\mathbf{1 0 0 \% )}\end{array}$ & $\begin{array}{c}\text { Preço com } \\
\text { CO2 }\end{array}$ & Preço & $\begin{array}{c}\text { (+10\%) } \\
\text { Investimento }\end{array}$ \\
\hline $20,0 \%$ & $\mathrm{R} \$ 138,23$ & $\mathrm{R} \$ 142,37$ & $\mathrm{R} \$ 142,80$ & $\mathrm{R} \$ 143,64$ & $\mathrm{R} \$ 146,97$ & $\mathrm{R} \$ 155,71$ \\
\hline $17,5 \%$ & $\mathrm{R} \$ 132,54$ & $\mathrm{R} \$ 136,10$ & $\mathrm{R} \$ 137,18$ & $\mathrm{R} \$ 137,43$ & $\mathrm{R} \$ 140,73$ & $\mathrm{R} \$ 148,93$ \\
\hline $15,0 \%$ & $\mathrm{R} \$ 126,87$ & $\mathrm{R} \$ 129,80$ & $\mathrm{R} \$ 131,51$ & $\mathrm{R} \$ 131,20$ & $\mathrm{R} \$ 134,44$ & $\mathrm{R} \$ 142,00$ \\
\hline
\end{tabular}




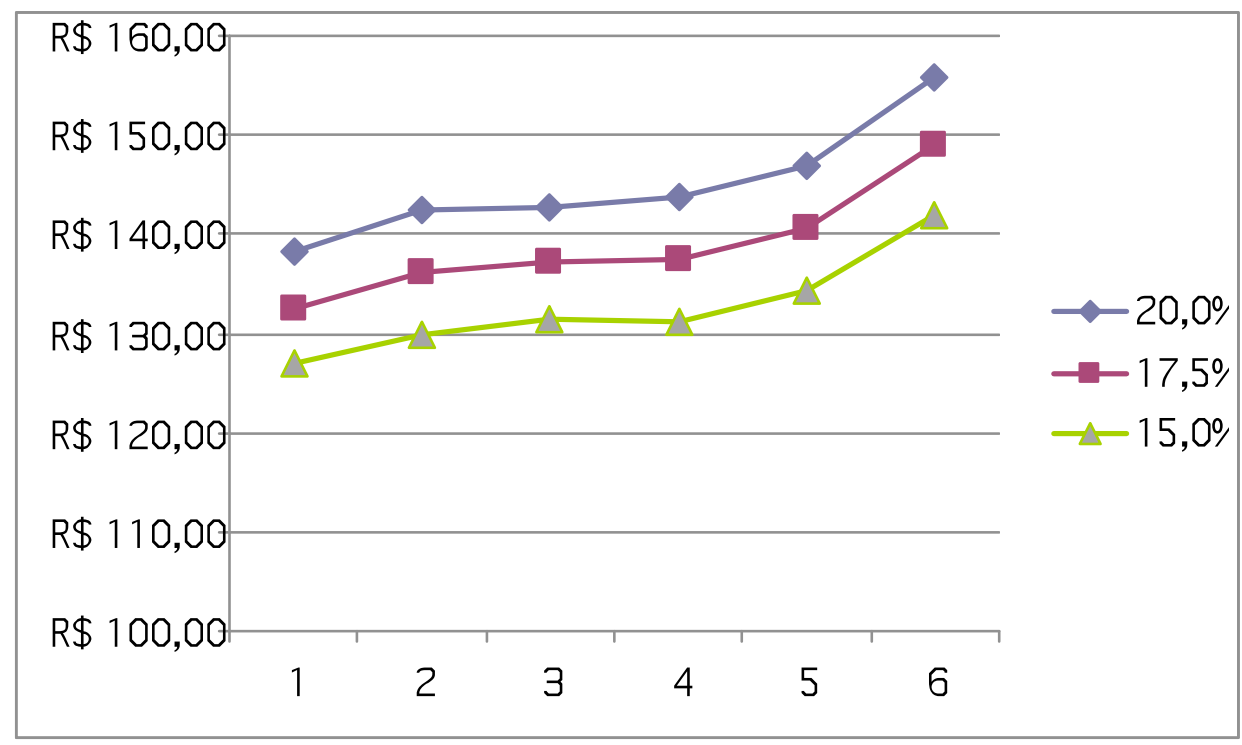

Figura 8.5.1 - Comparação do Preço da Energia de Biomassa com os Distintos Cenários Simulados 


\section{CAPÍTULO 9 - COMERCIALIZAÇÃO DE NOVAS FONTES DE ENERGIAS RENOVÁVEIS}

Conforme apresentado e discutido nos capítulos anteriores, a viabilização de uma comercializadora de energias renováveis depende fundamentalmente dos seguintes fatores:

- Marco regulatório apropriado

- Preço final da energia competitivo

- Política pública que valorize a descentralização e diversificação da matriz elétrica e seu desenvolvimento com tecnologias de baixo carbono.

- Condições apropriadas de financiamento e tarifa

- Valorização dos ganhos sócio-ambientais relacionados as tecnologias de menor impacto ambiental

Os pontos apresentados nos capítulos anteriores corroboram a necessidade de desenvolvimento de uma matriz elétrica com baixa emissão de GEE. O estudo apresenta o forte potencial de inserção das NFER na matriz elétrica e considera os principais casos internacionais de sucesso no crescimento das NFER. Além disso, este trabalho confirma a viabilidade econômica das NFER mesmo quando comparadas aos resultados dos leilões mais recentes.

A partir da compreensão dos pontos frágeis do Proinfa e do avanço de um marco regulatório para o aumento da participação das NFER no país, são colocadas as seguintes diretrizes para viabilizar sua comercialização.

1. A consideração econômica das fontes renováveis deve ultrapassar critérios como preço de mercado e incorporar outros aspectos técnicos e sócioeconômicos. O potencial de uma fonte renovável em uma determinada região deve ser maximizado e aproveitado, ao invés de restrito pelo limite de capacidade dos estados como inicialmente proposto no Proinfa. Benefícios sociais e ambientais devem ser internalizados no preço da energia, o que o sistema feed-in já faz em alguns casos. Outros parâmetros técnicos também devem se considerados tais como a economia de combustível pelo despacho evitado das usinas térmicas, a função das renováveis na manutenção do nível 
dos reservatórios hidrelétricos e a contribuição da geração descentralizada para reduzir custos de transmissão de energia. Os custos da inserção de eólicas e térmicas no sistema elétrico brasileiro foram comparados pela consultoria PSR (VEIGA, 2009). Somando-se a redução dos custos operativos das térmicas e a redução dos níveis de emissões, a inserção de 4000 MW médios de energia eólica não provocaria incremento de custo e reduziria o preço de liquidação de diferenças (PLD) em $R \$ 15,00 / M W h$.

2. É necessária uma estrutura regulatória que garanta a promoção da indústria nacional eólica, a exemplo do que tem ocorrido na China. Tal estrutura deve contar com incentivos fiscais e leis locais que criem condições favoráveis ao estabelecimento de fabricantes de turbinas eólicas. A desoneração de impostos aprovada pelo congresso nacional em 2009 teve impacto significativo no leilão de eólica deste mesmo ano. O desenvolvimento da pesquisa e inovação tecnológicas é de grande importância para a exploração da energia eólica no Brasil. Cada sítio de ventos exige a confecção de turbinas específicas e adaptadas às condições locais, de forma a aumentar seu rendimento. No Rio Grande do Norte, turbinas funcionam com geradores com fator de capacidade pouco acima de $30 \%$, quando o potencial local permitiria um aproveitamento superior a $40 \%$ e um ganho de receita consideravelmente superior. A condução destas pesquisas deve ser apoiada pelo governo e por empresas através de programas e parcerias com universidades e centros de pesquisa.

3. Uma próxima fase da política de incentivo às renováveis deve ajustar os níveis de nacionalização de serviços e equipamentos de forma mais criteriosa. Os índices visam o desenvolvimento da indústria eólica nacional, mas a expansão do parque gerador só vai ocorrer com a redução, em um primeiro instante, desta obrigação. A primeira fase do Proinfa mostrou claramente que $\mathrm{o}$ atendimento ao potencial contratado depende da importação de equipamentos. Adotar índices elevados de nacionalização só será coerente quando houver uma indústria nacional sólida a ser protegida. Desta forma, o ajuste do índice deve ser precedido de maiores incentivos ao desenvolvimento da indústria brasileira e à nacionalização de empresas. A 
liberação do índice de nacionalização no leilão de eólica de 2009 teve impacto positivo na competitividade e preços obtidos. $O$ resultado dos leilões de 2010 devem atrair um número maior de fabricantes para o país. Necessitamos ampliar a política de incentivos para o consumidor, promovendo uma maior conversão de consumidores cativos para geradores renováveis assim como mais benefícios fiscais para melhoramentos na área de eficiência térmica ou elétrica. Entre os incentivos adicionais, podemos listar: adoção de mecanismos para o aumento da aceitação local de renováveis, a divisão de encargos sobre consumidores, a eficientização de usinas através de repotencialização, a distribuição de custos de conexão de geradores à rede e a incorporação de ações de gerenciamento da demanda energética.

4. Medidas que assegurem a transparência das bases e objetivos das políticas e programas de incentivo às energias renováveis, simplificando a definição dos marcos regulatórios e das responsabilidades de cada agente do setor elétrico. Essas medidas servem para garantir sinalização, tempo e estratégia de planejamento para os investidores interessados (MALLON, 2006). Uma Lei de Energias Renováveis robusta continuará a ser a estratégia fundamental no desenvolvimento do setor elétrico, mesmo contando com o avanço tecnológico e expansão de mercado para as energias renováveis. A geração de eletricidade através das energias renováveis no Brasil ainda oferece um grande potencial de crescimento. As salvaguardas ambientais são fundamentais mesmo para as tecnologias renováveis de menor impacto. No Brasil a implementação de um novo marco regulatório para as renováveis deve adotar medidas que assegurem a transparência das bases e objetivos do programa, simplificando a definição de regulamentação pela ANEEL e da responsabilidades de agentes do setor elétrico.

5. Para garantir estabilidade ao mercado de fontes renováveis, o governo deve priorizar o acesso desses empreendimentos à rede elétrica e, ao mesmo tempo, direcionar investimentos de médio e longo prazos que contemplem o ciclo de desenvolvimento e implantação plena dessas tecnologias. Avalia-se que a aplicação das tarifas feed-in podem contribuir para este objetivo. Primeiramente, as obrigações contratuais entre as concessionárias de 
energia e os produtores de fontes renováveis dão a segurança necessária aos investidores. Em segundo lugar o tempo de duração do sistema tarifário influencia o retorno e a renda para o gerador; e finalmente a garantia do preço justo pago pela energia e a revisão periódica das tarifas mantém o mercado estável e gradualmente preparado para uma posterior fase de maior competitividade. No Brasil, o primeiro e segundo aspectos foram incorporados ao esquema de leilão. O terceiro, é justamente aquele que o esquema de leilão não pode proporcionar e que garantiria a viabilização da maior parte dos empreendimentos. O mercado de energia elétrica deverá ser 100\% aberto mantendo os setores de geração e comercialização competitivos, oferecendo preços diferenciados e acesso prioritário à rede para as NFER. Essa abertura de mercado permitirá que qualquer consumidor (incluindo o residencial) possa escolher livremente o seu gerador de energia. Isto ampliaria o mercado de comercialização de energia para consumidores de baixa tensão e o da classe residencial como acontece, com sucesso na Alemanha e na Espanha. No Brasil. Atualmente as oportunidades de mercado estão restritas a clientes corporativos pela lei 10.438/02.

6. Para garantir a competitividade das fontes renováveis, é essencial que ações sejam adotadas para reduzir os custos de distribuição. No leilão de energia eólica de 2009 várias medidas como a portaria 147 editada pelo MME em março de 2009 permitiram o compartilhamento das instalações de transmissão de interesse exclusivo de centrais de geração. Enquanto usinas de grande porte têm o custo da distribuição embutido em sua tarifa, os empreendedores das NFER (incluindo Proinfa) são obrigados a custear as despesas de distribuição. Este foi um dos principais motivos da baixa contratação de energia no leilão de energias alternativas realizado em 2007. Os contratantes encontraram uma opção de compra de energia mais barata no mercado livre, onde o preço não é fixo, mas a prática de desconto de $50 \%$ sobre a tarifa de transmissão acabou tornando o preço final inferior ao da energia contratada nos leilões. Assim, a tarifa de distribuição para projetos renováveis também deve receber descontos no mercado cativo, a fim de tornar estas fontes mais atrativas. As estações coletoras (ICGs) tem sido 
empregadas com sucesso para a biomassa e devem também ser aplicadas em empreendimentos eólicos.

7. É imprescindível que o foco de políticas públicas ou projetos de lei de incentivo seja restrito às fontes renováveis e não inclua apoio a combustíveis fósseis. Ao contrário do que acontece com a Conta de Consumo de Combustível (CCC) e a Conta de Desenvolvimento Energético, que são totalmente voltadas para a compra de combustíveis fósseis em comunidades isoladas. 


\section{CAPÍTULO 10 - CONCLUSÃO}

Apesar da dificuldade de se obter um acordo para uma redução consensual dos GEE nas recentes negociações climáticas, diferentes indícios de mudanças climáticas indicam urgência na mitigação de emissões desses gases. Embora a comunidade internacional não tenha atingido um consenso sobre estratégias de redução de emissões durante a Conferência das Partes do Painel Intergovernamental sobre Mudanças Climáticas das Nações Unidas, em Copenhague em 2009, o emprego de fontes de energia renovável foi uma estratégia concordada com unanimidade. Entretanto, a vontade política para transformar a matriz energética ainda deve ser traduzida em investimentos concretos na transferência tecnológica. Diferentes estudos mostram o potencial da criação de milhares de empregos verdes resultantes do desenvolvimento da indústria de energias renováveis e mostram que o custo econômico para evitar uma crise climática é inferior ao custo de se tentar remediar suas conseqüências nas próximas décadas (RUTOVITZ; ATHERTON, 2009).

Em âmbito global, as energias renováveis já foram incorporadas aos planejamentos energéticos de larga escala e são consideradas opções maduras do ponto de vista tecnológico e econômico. De acordo com o PNUMA, os investimentos em novas fontes de energia renovável chegaram a 155 bilhões de dólares em 2008, suprimindo os investimentos em termelétricas fósseis, em 110 bilhões de dólares.

Para aproveitar o potencial renovável do Brasil, é necessário partir de um programa bem estruturado de incentivos. O Proinfa, na condição de iniciativa pioneira, enfrentou vários problemas legislativos e de mercado. Alguns desses problemas foram corrigidos ao longo do programa, como a extensão de prazos e a revisão de índices; mas outros pontos persistem, mesmo nas novas propostas e mecanismos de incentivo a estas energias representadas pelos leilões exclusivos por fonte e pelo texto do substitutivo ao PL 630/03.

O estabelecimento de um mercado brasileiro de renováveis e o desenvolvimento tecnológico destas fontes passa necessariamente pela análise institucional dos principais mercados de energias alternativas. Os principais casos de sucesso de mercados energéticos internacionais são fruto de leis de incentivo 
que, ao garantir uma remuneração justa aos geradores, incluem benefícios diretos e indiretos de cada fonte à matriz energética, tanto na geração de energia limpa quanto em efeitos periféricos resultantes da criação e da sustentação de mercados (Greenpeace, 2008).

O principal exemplo de mecanismo que conjuga estes fatores é o feed-in. O sistema conseguiu uma ótima taxa de inserção dessas fontes a custos razoáveis aos consumidores finais (Greenpeace, 2008). Alguns países optaram por uma combinação entre instrumentos de incentivo a subsídios e flexibilização de impostos relacionados a equipamentos e serviços da cadeia de geração de energias renováveis.

A China vem sendo um exemplo de um país que alia tarifas prêmio a políticas industriais, obtendo resultados expressivos no desenvolvimento da indústria eólica: Nos últimos anos, a capacidade eólica da China vem aumentando em cerca de $50 \%$ ao ano, atingindo 25 mil MW ao final de 2009 (GWEC, 2010), colocando o país entre os três maiores produtores deste tipo de energia.

Em outros casos, tanto na Europa como no Brasil, provou-se que o mecanismo feed in aplicado da maneira incorreta, sem o acompanhamento de medidas industriais aliado a políticas complementares de incentivo e o aprimoramento dos procedimentos de obtenção de licenças tampouco garante resultados consistentes em curto ou mesmo médio prazo.

Já no caso dos leilões, as experiências internacionais ${ }^{26}$ e nacional têm mostrado que o sistema, por si só, é ineficiente para desenvolver indústrias de energias renováveis. Apesar de ter a vantagem de reduzir os custos das fontes renováveis ao estabelecer e estimular um preço competitivo, este preço tem resultado em uma baixa contratação de projetos nos leilões atrasando portanto a expansão da indústria nacional.

É possível obter um crescimento sólido e gradativo das fontes renováveis na matriz energética brasileira a partir da aplicação seqüenciada e correta de mecanismos de incentivo. O sistema feed-in - aplicado também em geração de grande porte - empresta estabilidade financeira ao empreendedor até um estágio de pleno desenvolvimento tecnológico que permita a competitividade destes projetos

\footnotetext{
${ }^{26} \mathrm{O}$ insucesso dos leilões na Califórnia - onde empreendedores fecharam contratos por meio de lances baixos, sem ter as condições financeiras de desenvolver os projetos - tem suscitado análises sobre as vantagens da atuação das tarifas feed in inclusive na implementação de projetos de grande porte [33].
} 
em leilões. Assim, o incentivo feito em um primeiro momento é compensado na etapa seguinte, com a redução do preço das tecnologias (DUTRA; SZKLO; 2008). Outra opção é substituir o incentivo tarifário pela isenção fiscal, o que daria condições às tecnologias de competir diretamente nos leilões.

Conforme verificado na simulação, os leilões não oferecem preços adequados para todas as tecnologias, ou regularidade na realização dos certames, duas condições essenciais para a sustentabilidade dos projetos e o desenvolvimento do mercado. Já a legislação proposta na Comissão Especial de Energias Renováveis delega a composição de preços dos leilões ao governo, no caso da geração de grande porte, e carece de ajustes na precificação de empreendimentos de pequeno porte - ainda que a geração solar receba $\mathrm{R} \$ 710 / \mathrm{MWh}$ no caso de microssistemas, os demais tipos de geração não tiveram valores fixados.

A implementação desta legislação está ameaçada. O substitutivo ao projeto de lei foi aprovado dentro da Comissão Especial, mas antes de seguir para o Senado Federal, foi encaminhado para votação em plenário na Câmara dos Deputados. O projeto espera por votação, sem um prazo definido. Considerando a redução dos trabalhos legislativos por conta das eleições de 2010, é possível que o país tenha que esperar bastante até a concretização de um marco regulatório sólido capaz de desenvolver diferentes mercados de energias renováveis.

No final do mês de agosto de 2010 foi realizado um leilão para contratação de energia de reserva específico para $\mathrm{PCHs}$, biomassa e eólica. Neste evento, a ANEEL estipulou o preço-teto para o megawatt-hora de energia eólica e biomassa em $\mathrm{R} \$ 167$ e de $\mathrm{R} \$ 155$ para a energia gerada por pequenas centrais hidrelétricas. Os resultados médios obtidos neste leilão ainda que considerados baixos para estas fontes ( $R \$ 130,86 / M W h$ para eólica, $R \$ 141,93 / M W h$ para $P C H s$ e $R \$ 144,20 / M W h$ para biomassa) são valores viáveis para biomassa e $\mathrm{PCHs}$ considerando a simulação elaborada pelo autor. No caso da energia eólica o valor obtido em leilão necessita uma taxa de retorno ao investimento menor que $15 \%$ e o fator de capacidade da planta maior que $42 \%$.

Os resultados da simulação elaborados para esta dissertação para energia eólica variam entre $\mathrm{R} \$ 136,69 / \mathrm{MWh}$ e $\mathrm{R} \$ 183,09 / \mathrm{MWh}$; para $\mathrm{PCHs} \mathrm{R} \$ 123,63 / \mathrm{MWh}$ e $\mathrm{R} \$ 175,44 / \mathrm{MWh}$; para biomassa $\mathrm{R} \$ 126,87 / \mathrm{MWh}$ e $\mathrm{R} \$ 155,71 / \mathrm{MWh}$. Em todos os casos as premissas adotadas seguem a linha de financiamento ofertadas pelo 
BNDES e os preços não contam com o impacto econômico da desoneração de impostos como atualmente ofertado para a projetos com tecnologia eólica.

Analisando os diversos resultados que indicam as distintas tendências de preços, podemos verificar que os leilões de energia de reserva de NFER apresentaram até agora um deságio maior do que o esperado mas ainda apresentam potencial de sucesso. Entretanto a definição do número de leilões, a quantidade de energia a ser comercializada e seu preço permanecem dependentes de uma decisão do governo federal. Esta dependência é um fator importante a ser considerado tanto na viabilização de uma comercializadora de NFER como na concretização de um mercado de NFER.

Como demonstrado nesta dissertação os países que apresentam mercados maduros e em crescimento de novas energias renováveis não contam com leilões esporádicos mas sim com um marco regulatório específico como a tarifa feed in.

Portanto, é fundamental que o Congresso Nacional aprove o PL 630 ainda no exercício de 2010. A aprovação de uma lei própria para o desenvolvimento de um mercado robusto de novas energias renováveis terá forte impacto na manutenção de uma matriz energética de baixa emissão de GEE, assim como na geração de empregos. Conforme apontado anteriormente o PL 630 também promove a descentralização e diversificação da matriz o que contribui para a maior segurança energética do sistema.

A instalação de uma comercializadora de novas energias renováveis no Brasil é economicamente viável, politicamente necessária e mercadologicamente desejada para atender a crescente demanda de consumidores que gostariam de contribuir com seu poder de compra na luta contra o aquecimento global. 


\section{REFRÊNCIAS BIBLIOGRÁFICAS}

[1] ABJAODE, CRISTIANO; Autoprodução: Interesse e condicionantes para a participação dos autoprodutores nos investimentos para a expansão da oferta, $8^{\circ}$. Encontro de Negócios de Energia, FIESP, São Paulo, em 20 de junho de 2007.

[2] AGÊNCIA NACIONAL DE ENERGIA ELÉTRICA, Resoluções Normativas, www.aneel.gov.br Brasília, 1999 a 2007. Acesso em outubro 2009.

[3] ALMEIDA PRADO JR., FERNANDO AMARAL, Oportunidades e Barreiras à geração distribuída, capítulo do livro Geração Distribuída; Editora Interciência, Rio de Janeiro 2006.

[4] ALMEIDA, ANDRÉ BREVIGLIERI E AMANN, KLAUS MOREIRA, Mercado livre: uma análise da percepção dos consumidores livres e reflexões sobre o cenário atual, Trabalho apresentado à Escola Politécnica da Universidade de São Paulo para a obtenção do certificado de especialista em Energia - MBA em Energia, 2007.

[5] ALMEIDA PRADO JR., FERNANDO AMARAL, Risco regulatório, trabalho apresentado à Escola Politécnica da USP como requisito para obtenção do título de Pós Doutor, São Paulo, 2005.

[6] AMARANTE, O.A.C., BROWER, M., ZACK, J. "Atlas do Potencial Eólico Brasileiro". Ministério de Minas e Energia e Eletrobrás. Brasília, 2001.

[7] ANEEL - AGÊNCIA NACIONAL DE ENERGIA ELÉTRICA - Resolução Normativa 067/2004, Brasília, 2004.

[8] ANEEL - Agência Nacional de Energia Elétrica - Resolução Normativa 077/2005, Brasília, 2005. 
[9] ANEEL - Agência Nacional de Energia Elétrica - Resolução Normativa 247/2006, Brasília, 2006.

[10] ANEEL - AGÊNCIA NACIONAL DE ENERGIA ELÉTRICA - Resolução Normativa 248/2007, Brasília, 2007.

[11] ANEEL - AGÊNCIA NACIONAL DE ENERGIA ELÉTRICA - Resolução Normativa 271/2007, Brasília, 2007.

[12] ANEEL, Banco de Informações de Geração - BIG 2009. www.aneel.gov.br Acesso em outubro 2009.

[13] APMPE - Inserção das energias alternativas renováveis no setor elétrico brasileiro, 3․ Fórum brasileiro de Infra-estrutura, Brasília, julho, 2003.

[14] BALANÇO ENERGÉTICO NACIONAL (BEN) 2009. EPE - Empresa de Pesquisas Energéticas. Rio de Janeiro, 2009. Acesso em outubro 2009.

[15] BANDEIRA, FAUSTO DE PAULA MENEZES, Análise das alterações propostas para o modelo do setor elétrico brasileiro; Estudo da Consultoria Legislativa da Câmara dos Deputados, Brasília, agosto de 2003.

[16] BERMANN, C. "As Novas Energias no Brasil - Dilemas da Inclusão Social e Programas de Governo, Capítulo 2: Proinfa: Da Proposta à Realidade", Rio de Janeiro, 2007.

[17] BRITO, A. "Usinas pequenas devem triplicar geração", Folha de São Paulo, Publicado em 20 de julho de 2009.

[18] CÂMARA AMERICANA DE COMÉRCIO - AMCHAM, A Utilização da Tarifa de Energia Elétrica como Fonte Arrecadadora de Tributos, São Paulo, 2004. 
[19] CAMARA DOS DEPUTADOS - Projeto de Lei do Senado 27/1996 http://www.camara.gov.br/sileg/Prop Detalhe.asp?id=32911 acesso em julho 2010.

[20] CAMARA DOS DEPUTADOS - Substitutivo ao Projeto de Lei 2905-2000 http://www.camara.gov.br/sileg/Prop Detalhe.asp?id=18801 acesso em julho 2010.

[21] CANAZIO, A., "Proinfa: empreendimentos atrasados têm até 28 de fevereiro para entrar em operação". Publicado no Canal Energia em 23 de janeiro de 2009. http://www.canalenergia.com.br

[22] CAPDEVILLE, CHARLES \& OLIVEIRA, ANDRÉ, A importância da fiscalização e da regularização de ligações clandestinas. Uma Política comercial para as distribuidoras de energia elétrica; Monografia apresentada à Escola Politécnica da USP para obtenção do título de especialista em energia, no curso de MBA em energia, São Paulo, 2007.

[23] CHIPP, H. "Oportunidades da Biomassa de Cana na Oferta de Bioeletricidade". Apresentação no II Fórum Cogen/Canal Energia, em 24 de julho de 2009.

[24] CONGRESSO NACIONAL - Lei 9074, Brasília, 1995.

[25] CONGRESSO NACIONAL - Lei 9.427, Brasília, 1996.

[26] CONGRESSO NACIONAL - Lei 10.438, Brasília, 2002.

[27] CONGRESSO NACIONAL - Lei 10.762, Brasília, 2003.

[28] CONGRESSO NACIONAL - Leis 10.847 e 10.848, Brasília, 2004.

[29] CONGRESSO NACIONAL - Leis 11.488, Brasília, 2007. 
[30] COSTA, C.V; As Políticas de Promoção de Fontes Renováveis para Geração de Energia Elétrica: Lições da Experiência Européia para o Caso Brasileiro, Tese de Doutorado, COPPE - Universidade Federal do Rio de Janeiro, 2006.

[31] COUTURE, T., CORY, K. "State Clean Energy Policies Analysis (SCEPA) Project: An Analysis of Renewable Energy Feed-in Tariffs in the United States" Technical Report, National Renewable Energy Laboratory, 2009.

[32] DAMME, ERIC VAN; ZWART, GIJSBERT; The liberalized Dutch green electricity market: lessons from a policy experiment, artigo apresentado na Conference "Competition and Market Power: Measurement, Theory and Implications", Groningen, December, 2002.

[33] DELTA ENERGIA, News Letter, abril e maio de 2007.

[34] DEPARTMENT OF ENERGY, Status of State Electric Industry Restructuring $\begin{array}{llll}\text { Activity. Acesso em } & \end{array}$ http://www.eia.doe.gov/cneaf/electricity/chg str/restructure.pdf

[35] Development of Renewable Energies in 2006 in Germany. Federal Ministry for the Environment, Nature Conservation and Nuclear Safety, 2007.

[36] FILHO, D.K. "Estrutura Tarifária da Energia Elétrica e Competitividade Industrial", Apresentação no $10^{\circ}$ Encontro de Negócios de Energia organizado pelo CIESP - Centro das Indústrias do Estado de São Paulo, com o apoio e coordenação técnica da FIESP - Federação das Indústrias do Estado de São Paulo, 05/10/2009.

[37] DUTRA, R. M. "Viabilidade Técnico-Econômica da Energia Eólica Face ao Novo Marco Regulatório do Setor Elétrico Brasileiro" Dissertação de Mestrado pela Universidade Federal do Rio de Janeiro, UFRJ. Rio de Janeiro, 2001. 
[38] DUTRA, R. M. "Propostas de Políticas Específicas para Energia Eólica no Brasil após a Primeira Fase do Proinfa." Tese de Doutorado pela Universidade Federal do Rio de Janeiro, UFRJ. Rio de Janeiro, 2007.

[39] DUTRA, Ricardo Marques ; SZKLO, A.S. " Incentive Policies for Promoting Wind Power Production in Brazil: Scenarios for the Alternative Energy Sources Incentive Program (PROINFA) Under the New Brazilian Electric Power Sector Regulation”. Renewable Energy, v. 33, p. 65-76, 2008.

[40] EMPRESA DE PESQUISAS ENERGÉTICAS - EPE, "Índice de Custo Benefício (ICB) de Empreendimentos de Geração Termelétrica - Metodologia de Cálculo" Nota Técnica, 2006.

[41] EPE - EMPRESA DE PESQUISAS ENERGÉTICAS - Cenários Macro Econômicos para Projeção do mercado de energia elétrica, Brasília, 2006.

[42] EPE - EMPRESA DE PESQUISAS ENERGÉTICAS - Plano Decenal de Expansão 2006-2015, Brasília, 2006.

[43] FELISBERTO, C. \& SZKLO, A. Proinfa e CDE: questionamentos sobre a legislação e regulamentação. PPE/COPPE/UFRJ, 2004.

[44] "Financing Instruments and Models" - Sepco - Sustainable Energy Policy Concepts - International Solar Energy Society - http://www.ises.org Acesso em outubro 2009.

[45] Global Wind Energy Council - http://www.gwec.net Acesso em outubro 2009.

[46] GARCIA, F.; SOUZA, R. C.B., CÂMARA, S.; Impactos econômicos de alteração nos preços do óleo combustível e do gás natural, FGV, São Paulo, 2003.

[47] GIANNOTTI, J. R.; Abastecimento de Energia Elétrica e a competitividade da Economia Brasileira in $6^{\circ}$. Encontro de Negócios de Energia, CIESP, São Paulo, 2005. 
[48] GOLDEMBERG, J. "The case for renewable energies". Thematic background paper, International Conference for Renewable Energies, Bonn, 2004.

[49] GONÇALVES, J.A. Contagem Regressiva. Revista Página 22, Julho, 2007.

[50] GOY, L. "Projetos para energia eólica já somam quase uma Itaipu". O Estado de São Paulo. Publicado em 17 de julho de 2009.

[51] GRACE, R.C.; RICKERSON, W.; Porter, K.; DeCesaro, J.; Corfee, K.; Wingate, M.; Lesser, J. (2008). California Feed-in Tariff Design and Policy Options, Second Draft. California Energy Commission, 2008.

[52] GREENPEACE, EUROPEAN RENEWABLE ENERGY COUNCIL 2007. Energy [R]evolution Report.

[53] GREENPEACE, "A Caminho da Sustentabilidade Energética". São Paulo, 2008.

[54] GREINER, P. Bases para um modelo auto-regulador para o setor elétrico brasileiro. Tese de Doutorado em Administração, Escola de Administração de Empresas da Fundação Getúlio Vargas, 1994.

[55] GREINER, P. O apagão do setor elétrico: causas, verdades e equívocos. Texto divulgado na rede mundial de computadores, São Paulo, 2001.

[56] IPCC - Intergovernmental Panel on Climate Change, Fourth Assessment $\begin{array}{llll}\text { Report } & - & \text { Climate } & \text { Change }\end{array}$ http://www.ipcc.ch/publications and data/publications and data reports.htm\#1 acesso em outubro 2009.

[57] KLEIN, A.; PFLUGER, B.; HELD, A.; RAGWITZ, M.; RESCH, G.; FABER, T. "Evaluation of Different Feed-in Tariff Design Options - Best Practice Paper for 
the International Feed-in Cooperation: 2nd edition." Fraunhofer Institute Systems and Innovations Research. Alemanha, 2008.

[58] LEAL, M. "Associação sugere ao MME realização de leilão específico para pequenas centrais hidrelétricas", Jornal da Energia. Publicado em 30 de julho de 2009. http://www.revistagtd.com.br

[59] MAGOSSI, E., BAHNEMANN, W. "Geração de Biomassa ganha espaço no país", Agência Estado. Publicado em 4 de agosto de 2009.

[60] MALLON, K. "Renewable Energy Policy and Politics - A handbook for decision making". Earthscan, 2006.

[61] MALLON, K. "Using the Federal Production Tax Credit to Build a Durable Market for Wind Power in the United States" Publicado em The Electricity Journal, Elsevier, 2007.

[62] MELLO, JOÃO CARLOS DE OLIVEIRA, Estruturas de Mercado de Energia Elétrica no Mundo, Estudo desenvolvido pela Consultoria Andrade \& Canellas para a ABRACE, São Paulo, 2003. Brasília, agosto de 2003.

[63] MINISTÉRIO DE MINAS E ENERGIA, Balanço Energético Nacional 2009 (ano base 2008), www.mme.gov.br Acesso em outubro 2009.

[64] MINISTÉRIO DE MINAS E ENERGIA, Decreto 5.163, Brasília, 2004.

[65] MINISTÉRIO DE CIÊNCIA E TECNOLOGIA, Inventário de Emissões e Remoções Antrópicas de Gases de Efeito Estufa não Controlados pelo Protocolo de Montreal, http://www.mct.gov.br/index.php/content/view/57270.html. Acesso em outubro 2009.

[66] OFGEM, Guidelines on green offerings, www.ofgem.gov.uk Acesso em outubro 2009. 
[67] OPERADOR

NACIONAL

DO

SISTEMA

ONS,

http://www.ons.org.br/historico/carga propria de demanda out.aspx

acesso em março 2010.

[68] PEREIRA, O.L.S. "Longe de uma matriz elétrica sustentável". Valor Econômico., publicado em 30 de julho de 2009.

[69] PLANO DECENAL DE ENERGIA. EPE - Empresa de Pesquisas Energéticas. Rio de Janeiro, 2009.

[70] PNUMA - Programa das Nações Unidas para o Meio Ambiente, "Tendências Globais de Investimentos em Energias Renováveis", 2009.

[71] PIRES, J. C. L.; GOSTKORZEWICZ, J., GIAMBIAGI, F; O Cenário Macroeconômico e as condições de oferta de energia elétrica no Brasil, texto de Discussão 85 do IPEA - Instituto de Pesquisa Econômica Aplicada, Rio de Janeiro 2001.

[72] PORTER, MICHAEL, Parem de gastar tanto dinheiro, Entrevista Guia Exame sustentabilidade, Editora Abril, São Paulo, 2007.

[73] PORTO, L., Ministério de Minas e Energia, Palestra proferida no Departamento de Engenharia de Energia e Automação Elétricas, Escola Politécnica da USP, São Paulo, em 27 de agosto de 2007.

[74] ALMEIDA PRADO, F.A., HEIDEIER, R. B."O crescimento da intensidade de emissões de gases de efeito estufa na matriz elétrica brasileira - uma visão crítica"- XVIII Seminário Nacional de Distribuição de Energia Elétrica. Não publicado.

[75] RICKERSON, W.; GRACE, R.C. "The Debate over Fixed Price Incentives for Renewable Electricity in Europe and the United States: Fallout and Future Directions". Washington D.C.: Heinrich Boll Foundation, 2007 
[76] ROSA, L. P., Energia Elétrica e Gás Natural no Brasil, palestra na FIESP, São Paulo, Janeiro de 2007.

[77] RUtOVITZ, J., ATHERTON, A. "Energy Sector Jobs to 2030: a Global Analysis". Institute for Sustainable Futures, University of Technology, Sidney, 2009.

[78] SCARAMUZZO, M. , GOULART, J. "Crise do setor sucroalcooleiro afeta os projetos de cogeração de energia". Valor Econômico. Publicado em 17 de julho de 2009.

[79] SWARC, A. "Bioenergia da Cana: Contribuição para o PL 630/03", Apresentação à Comissão Especial de Energias Renováveis da Câmara dos Deputados, em 15 de abril de 2009.

[80] SZKLO, A. S.; FELISBERTO, C. R. M. . PROINFA e CDE: questionamentos sobre a legislação e a regulamentação. In: Congresso Brasileiro de Planejamento Energético - CBPE, 2004, Itajubá - Minas Gerais. Anais do Congresso Brasileiro de Planejamento Energético, 2004.

[81] TAVARES, M., Restrição da oferta de GN alternativas comerciais para os consumidores industriais, $8^{\circ}$. Encontro de Negócios de Energia FIESP, São Paulo, em 20 de junho de 2007.

[82] TESKE, S., "Target for Clean Energy- The Greenpeace Position for a New Renewable Energy Electricity Directive”, 2005.

[83] VEIGA, M. "Inserção de Energia Eólica: Desafios e Oportunidades", Apresentação à Comissão Especial de Energias Renováveis da Câmara dos Deputados, em 18 de fevereiro de 2009. 
[84] WISER, RYAN H.; The Role of Public Policy in Emerging Green Power Markets: An Analysis of Marketer Preferences, University of California, Berkeley, EUA, 1999.

[85] ZINDLER, E. "The American Recovery and Reinvestment Act: A User's Guide." London, England: New Energy Finance, 2009. 